\title{
Water Resources of
}

the Neuse River Basin

North Carolina

GEOLOGICAL SURVEY WATER-SUPPLY PAPER 1414

Prepared in cooperation with Division of Water Resources, Inlets and Coastal Waterways, North Carolina Department of Conservation and Development

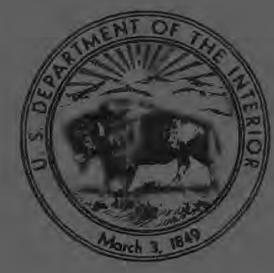




\section{Water Resources of}

the Neuse River Basin North Carolina

By G. A. BILLINGSLEY, R. E. FISH, and R. G. SCHIPF

GEOLOGICAL SURVEY WATER-SUPPLY PAPER 1414

Prepared in cooperation with Division of Water Resources, Inlets and Coastal Waterways, North Carolina Department of Conservation and Development

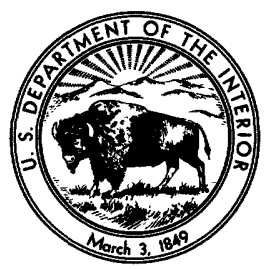




\title{
UNITED STATES DEPARTMENT OF THE INTERIOR
}

\author{
FRED A. SEATON, Secretary
}

\section{GEOLOGICAL SURVEY}

Thomas B. Nolan, Director 


\section{PREFACE}

The report on the resources of the Neuse River basin is one of a series of reports describing the water resources of North Carolina. When the contemplated series of reports is completed, information for the entire State will be available to assist in the orderly planning and development of the water facilities required for municipal and industrial expansion, and for the expansion of the uses of water in agriculture.

This report was prepared by the U. S. Geological Survey, in cooperation with the Division of Water Resources, Inlets, and Coastal Waterways of the North Carolina Department of Conservation and Development. Many individuals in the Water Resources Division contributed to the preparation of this report.

Most of the data summarized in this report have been collected over a period of many years by the U. S. Geological Survey in cooperation with the North Carolina Department of Conservation and Development, the State Board of Health, and the Corps of engineers, U. S. Army, Wilmington, N. C.

Other data and information presented in this report are based on data collected by, in cooperation with, or are from technical reports, or publications, of the U. S. Weather Bureau, North Carolina State Stream Sanitation Committee, and the North Carolina State Highway and Public Works Commission. 



\section{CONTENTS}

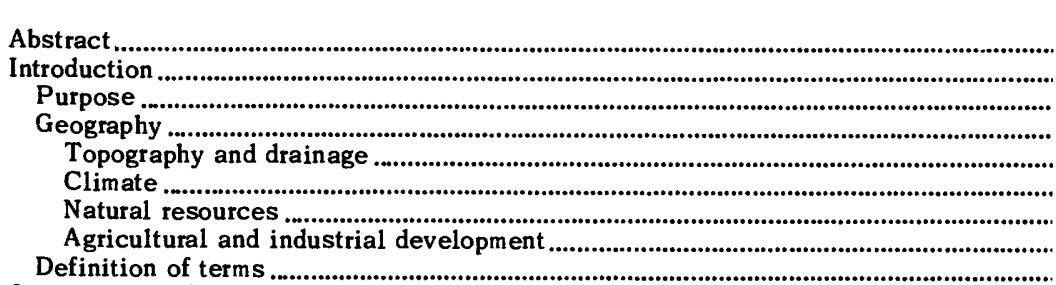

Occurrence and quality of water.

The hydrologic cycle

Sources of water.

Significance of quality of water

Surface water.

Flow characteristics

Duration of flow

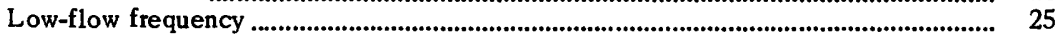

Maximum peried of deficient discharge ......................................................................... 32

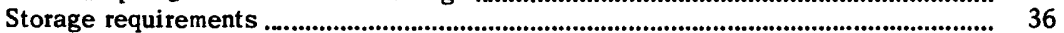

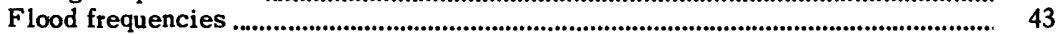

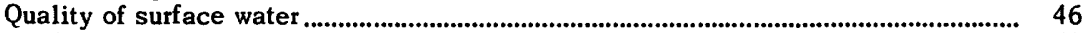

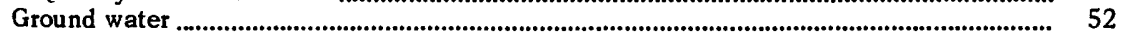

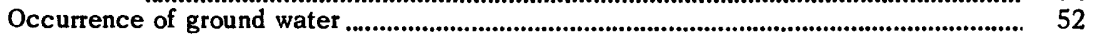

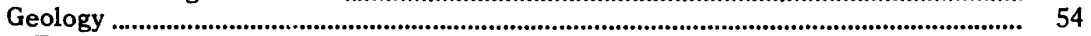

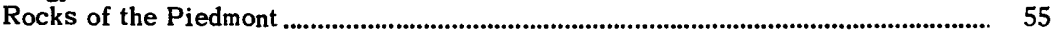

Rocks of the Coastal Plain ....................................................................................... 56

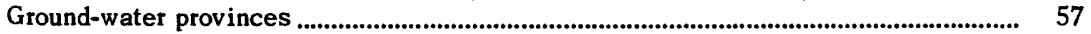

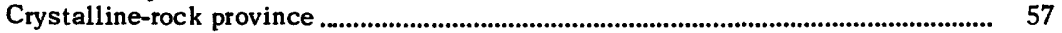

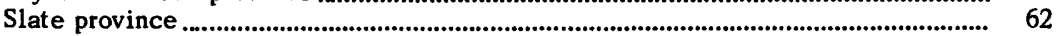

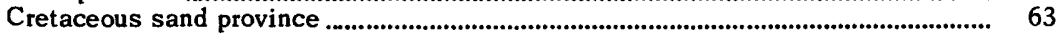

Tertiary limestone province ..................................................................................... 64

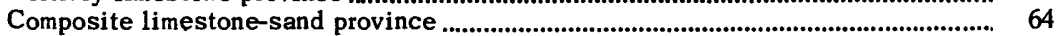

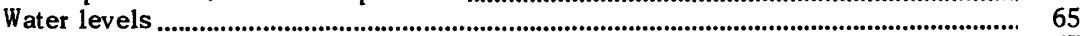

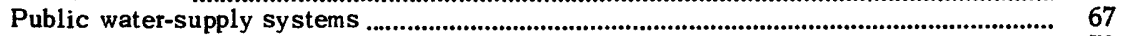

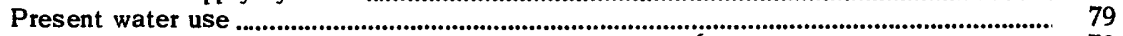

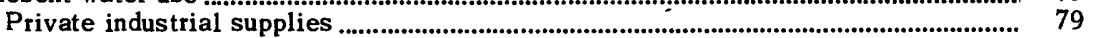

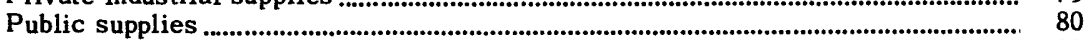

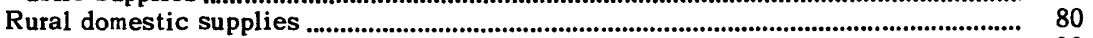

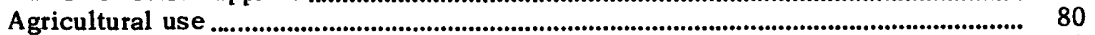

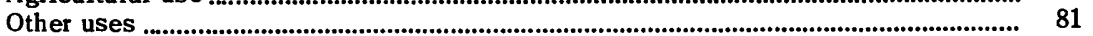

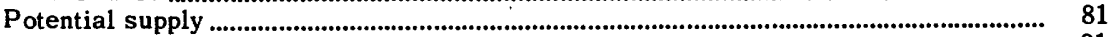

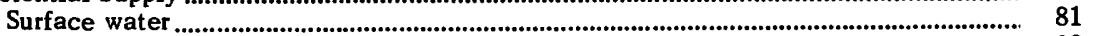

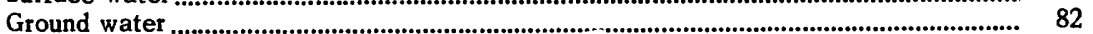

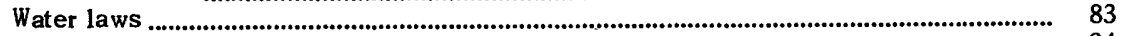

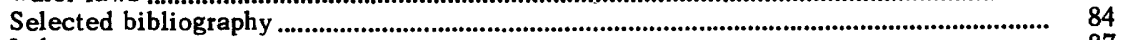

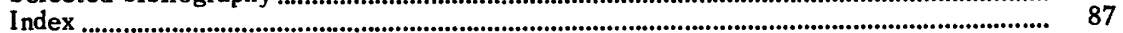




\section{IL LUSTRATIONS}

[All plates in pocket]

Plate 1. Map of Neuse River basin showing stream-gaging stations and quality of water sampling sites.

2. Map of Neuse River basin showing ground-water provinces،

3. Hardness and dissolved-solids content of water from public supplies in the Neuse River basin.

Figure 1. Precipitation and air temperature at Raleigh

2. Precipitation and air temperature at Goldsboro

3. Precipitation and air temperature at Goldsboro

4. Duration of records at gaging stations in the Neuse River basin ................... 18

5. Duration curve of daily flow, Flat River at Bahama and Neuse ........................ 21

6. River near Clayton

6. Duration curve of daily flow, Middle Creek near Clayton ...................................... 22

7. Duration curve of daily flow, Little River near Princeton .................................... 22

8. Magnitude and frequency of annual low flows, Flat River at Bahama, based on period $1928-53$

9. Magnitude and frequency of annual low flows, Neuse River near Clayton, based on period 1928-53

10. Magnitude and frequency of annual low flows, Middle Creek near Clayton...

11. Magnitude and frequency of annual low flows, Little River near Princeton..

12. Maximum period of deficient discharge, Flat River at Bahama and Neuse River near Clayton

13. Maximum period of deficient discharge, Middle Creek near Clayton................

14. Maximum period of deficient discharge, Little Creek near Princeton ...............

15. Storage tequirements, F lat River at Bahama and Neuse River near Clayton

16. Storage requirements, Middle Creek near Clayton

17. Storage requirements, Little River near Princeton.

18. Flood-stage frequencies, Neuse River near Northside and near Clayton .......

19. Flood-stage frequencies, Neuse River near Goldsboro and at Kinston ............

20. Average composition of dissolved solids of surface waters in the Neuse River basin

21. Relation of hardness to dissolved solids of surface waters in the Neuse River basin

22. Relation between streamflow and selected chemical and physical characteristics of Neuse River near Clayton, 1943-44

23. Generalized cross section of the Neuse River basin showing the major rock units

24. Chemical character of selected ground water in the Neuse River basin

25. Distribution graph of hardness and iron content of ground water in the Neuse River basin

26. Chart showing the fluctuation of the water level in a shallow observation well near the gaging station on the Neuse River near Northside

\section{TABLES}

Table 1. Water quality tolerances for industrial applications

2. Stream-gaging sites and sites for sampling quality of water in the Neuse River basin

3. Duration of daily flow in the Neuse River basin, $1928-53$

4. Magnitude and frequency of annual low flow in the Neuse River basin for periods of $1,7,30,60$, and 90 days, based on records of April 1, 1928, to March 31, 1953

5. Lowest flow for 7 consecutive days in each year in Neuse River basin,

6. Maximum number of consecutive days when discharge in the Neuse River basin was less than that indicated, 1928-1953 
Table 7. Storage requirements in Neuse River basin, 1928-53

8. Summary of chemical analyses of water from streams of the Neuse

9. Summary of chemical analyses of ground waters in the Neuse River basin

10. Chemical analyses of water from public water supplies in the Neuse River basin 


-




\title{
WATER RESOURCES OF THE NEUSE RIVER BASIN
}

\section{NORTH CAROLINA}

\author{
By G. A. Billingsley, R. E. Fish, and R. G. Schipf
}

\begin{abstract}
Sufficient water is available in the Neuse River basin to meet present requirements and those for many years to come if water use continues to increase at about the present rate. Data presented in this report show that the average annual streamflow from approximately 70 percent of the basin area during the 26-year period, 1928-53, was about $2,500 \mathrm{mgd}$. Comparison of this flow, with the estimated total withdrawal use of both surface and ground water of $280 \mathrm{mgd}$ indicates the relative utilization of the potential water resources of the basin. If proper pollution controls are observed and practiced so that water in the various streams may be reused a number of times, the potential for water-resources developments and use is even greater than indicated by the above comparison. Preliminary studies indicate that the quantity of water now being withdrawn from ground-water reservoirs in the basin is but a fraction of the total that may be obtained from this source.

Only 10 of the 43 municipalities having public water-supply systems use surface water; however, since 5 of the 10 are the largest cities in the area, about 60 percent of the water used for public supplies is from surface sources.
\end{abstract}

Of the 14 complete-record stream-gaging stations in the Neuse River basin, for which records are available, 11 have been in operation for 25 years or longer. Periodic measurements of the rate of flow have been made at 15 additional sites on streams scattered widely over the basin. All available streamflow data to 1953 have been summarized in either graphic or tabular form, or both. Analyses of streamflow records indicate that there is no significant long-term trend, either an increase or a decrease, in the volume of water flowing in the streams of the Neuse River basin.

Domestic supplies and supplies for small municipalities and industries in the Piedmont region are available almost everywhere from wells; the yields of individual wells vary greatly, ranging from about 1 to $200 \mathrm{gpm}$, and averaging about $30 \mathrm{gpm}$. In the Coastal Plain, yields of wells from poorly consolidated beds of sand and limestone are commonly more than $200 \mathrm{gpm}$. Both the water table and the artesian water level are generally controlled by natural conditions and, consequently, have shown no perennial decline. In certain areas near the coast, a body of salt water lies beneath the fresh water in the underground reservoir, and it is important in those areas that wells be properly spaced and pumping regulated so that well supplies are not contaminated with salt water.

Generally the surface waters in the Neuse River basin are of better chemical quality than ground water. Except for those streams affected by encroachment of sea water, the surface waters are low in dissolved mineral matter and are soft. Some surface waters contain excessive quantities of iron. Many of the streams in the basin receive polluting waste from surface sources making those waters unsuitable for many uses, Streams in the lower part of the basin are highly colored because of the drainage from swamp streams. The observed hardness of ground waters ranged from 2 to $750 \mathrm{ppm}$ as compared with 11 to $112 \mathrm{ppm}$ for surface waters in the basin.

Ground water from the crystalline-rock province of the Piedmont and from the slate province of the fall line is more variable in quality than water from other provinces in the area. The dissolved solids ranged from 43 to $1,460 \mathrm{ppm}$ with a median of $108 \mathrm{ppm}$ in the crystalline-rock and slate provinces. The Tertiary limestone province yields a calcium bicarbonate water ranging in hardness from 110 to $391 \mathrm{ppm}$. 


\section{INTRODUCTION}

\section{PURPOSE}

Water is one of the most important natural resources in the Neuse River basin. In the past, little thought was given to the availability of water resources, but a series of severe droughts in recent years has focused attention on the fact that our usable water supplies are not limitless - even in the humid southeastern states. The great natural increase in population, the expansion of industrial facilities, and the great demands on agricultural production, have generally impressed the public with the need for accurate and continuing appraisals of water resources and their development so as to meet the accelerating demands for water.

In 1953, the General Assembly of North Carolina established the Neuse River Watershed Authority (NRWA) to aid in planning the development of the varied resources of the basin. Many factors influence the economic growth of any region but the basic factor is adequate water supplies for public, industrial, rural domestic, agricultural, and other uses. These supplies must furnish not only a sufficient quantity of water but also water of satisfactory chemical and physical quality.

This report has been prepared to summarize and evaluate the data now available on the quantity and quality of both surface and ground water in the Neuse River basin. It is hoped that the report will assist in the location, development, or expansion of municipal, industrial, agricultural, and other water supplies and, perhaps, be a guide for the future study of water resources in the area.

\section{GEOGRAPHY}

The Neuse River basin is in east-central North Carolina. Its area, approximately 6,000 square miles, lies entirely within the boundaries of the State and is considered in this report to extend to Core Sound and to include the Newport River basin in Carteret County. The Neuse River basin is almost 200 miles long, extending from Orange and Person Counties in the northwest to the Atlantic Ocean bordering Carteret County in the southeast. The basin ranges in width from 35 to 45 miles through most of its length and includes about 11 percent of the area of North Carolina.

There has been a sharp upward trend in population in the Neuse River basin since 1940 and the present population is about 625,000 , or about 15 percent of the population of North Carolina. There 
are several cities in the basin, including Raleigh, Durham, Goldsboro, Wilson, Kinston, and New Bern, but the region is chiefly one of small towns and a large (42 percent) rural population.

\section{TOPOGRAPHY AND DRAINAGE}

The Neuse River basin lies in two physiographic regions that differ considerably in topography, geology, and hydrology. Almost 40 percent of the basin is in the Piedmont region; the remainder is in the Coastal Plain. At some places, falls and rapids are found where streams leave the hard rocks of the Piedmont to cut into the softer rocks of the Coastal Plain. The area where these falls or rapids occur is known as the fall line. The approximate boundary between the Piedmont and Coastal Plain may be considered a line drawn between Renson and Wilson.

The entire basin has a general surface slope toward the southeast and most of the streams, therefore, flow in that direction. Near the northwestern end of the basin, several hills reach elevations of 800 feet above sea level but the surface becomes lower as the fall line is approached and at elevations of 100 to 200 feet the Coastal Plain is entered. Farther to the southeast, sea level is reached in the estuary of the Neuse River.

The Piedmont section was formerly a gently sloping plain. The area was raised to its present elevation, and streams cut down into the rock to form the present hilly terrain. The northwestern quarter of the region is underlain by slate and schist, the next quarter by shale and sandstone of the Newark group. The third quarter is underlain by granite and gneiss, whereas the rocks in the southeastern quarter are slate and schist similar to those in the northwestern part of the basin. The slate is covered, toward the southeast by the clay and sand of the Coastal Plain strata.

The rocks of the Piedmont have been altered by various physical and chemical processes so that a moderately deep zone of reddish soil and soft, decayed rock is characteristic of the region. The surface is rolling to hilly in many places, especially near the streams, but broad upland areas and long ridges are also common where the rocks are more resistant to erosion.

The streams are generally swift flowing but many of them are bordered by swampy bottom land. The stream pattern when viewed from above in the upper part of the Piedmont resembles a branching oak tree, but in some places, where the harder rocks have fractures, streams tend to cut their channels in the fractured zones and make right angle turns where the fractures meet. In the lower 
Piedmont, near the fall line, the streams generally flow parallel to each other, as the Coastal Plain streams do, because they were developed on rocks that have been almost completely eroded away.

The Coastal Plain region is underlain by sedimentary rocks, chiefly sand, clay, and limestone (Cretaceous and Post-Cretaceous) but the surface is generally covered by light-colored, loose sandy soil. From the fall line to the vicinity of New Bern, the Coastal Plain surface is gently to moderately undulating but slopes are very steep at many places near the lar ger streams. The land is generally well drained but swamps are found in the bottom lands along the creeks.

During past geologic ages the sea reached far inland several times, and the latest flooding occurred during the comparatively recent Pleistocene epoch. As the sea retreated, the streams had to extend themselves farther and farther to reach the coast and tended to flow parallel to each other for some distance before joining a larger stream. Many of the tributaries to the Neuse, such as Contentnea Creek, flow parallel to the main stream for many miles before entering it. For about a third of its length, from Smithfield to Kinston, the Neuse River flows verv close to the southern boundary of its basin and most of its larger tributaries enter the main stream from the north.

Southeast of New Bern, the stream gradients are solow that natural drainage is inadequate, and extensive swamps exist in this area. Although the area was uplifted from the sea in recent geologic time, it has again been drowned to some extent since the drainage was established, creating many salt marshes and estuaries, or drowned rivers.

Several long barrier islands, offshore bars, and other coastal landforms have been built by wave action and by ocean currents some distance from the mainland. The barrier islands, known as the "outer banks", have typical sand-dune topography. The action of wind and waves during violent storms effects great changes in the physiography of this coastal region.

\section{CLIMATE}

The Neuse River basin has a humic climate and because of the length of the basin and its extension from the inland Piedmont region to the Atlantic Ocean, the re are minor variations in climate through the area.

Precipitation occurs chiefly as rainfall and varies with the seasons and with elevation. The mean annual precipitation ranges from 42 inches at the northwestern end of the basin to 55 inches near the coast at New Bern. This rainfall is generally well distributed through the year but is greatest during the summer and early fall. The heaviest monthly rainfall recorded in the basin is 17.60 inches 
(New Bern, July 1908) but the average is only a quarter of that amount.

Mean annual temperatures also vary from northwest to southeast, being about $59^{\circ} \mathrm{F}$ in the upper Piedmont section of the basin and about $63^{\circ} \mathrm{F}$ near the coast. Temperatures vary seasonally and are highest, of course, during the summer months, generally reaching a peak in July. The highest temperature recorded in the basin is $108^{\circ} \mathrm{F}$ (Goldsboro, July 1932).

The growing season ranges from 210 days in Person County to 269 days in Carteret County. Seasonal variations in precipitation and temperature at three weather stations in the Neuse River basin are shown in figures 1,2 , and 3 .
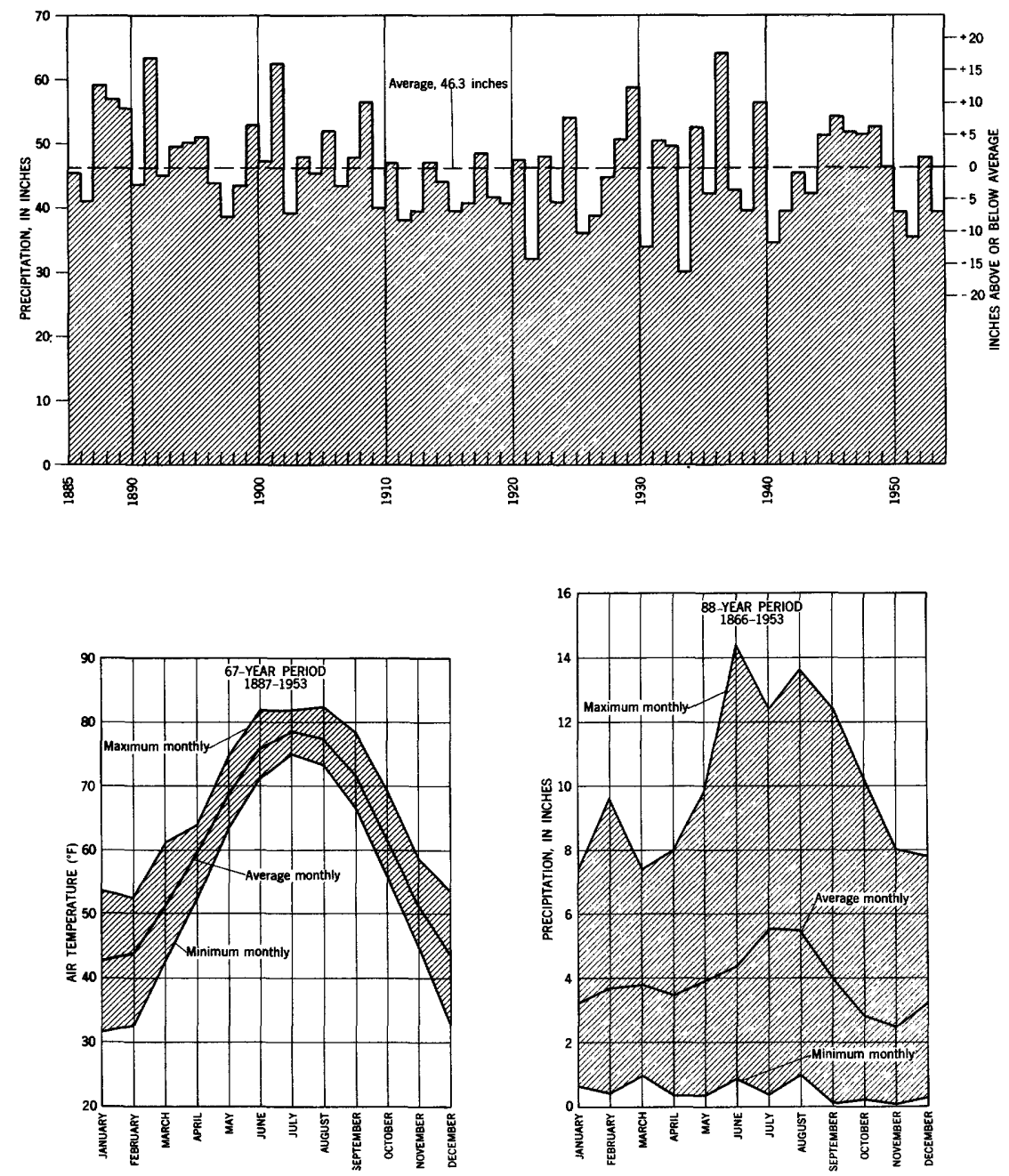

Figure 1-Precipitation and air temperature at Raleigh, N. C. (U. S. Weather Bureau data). 

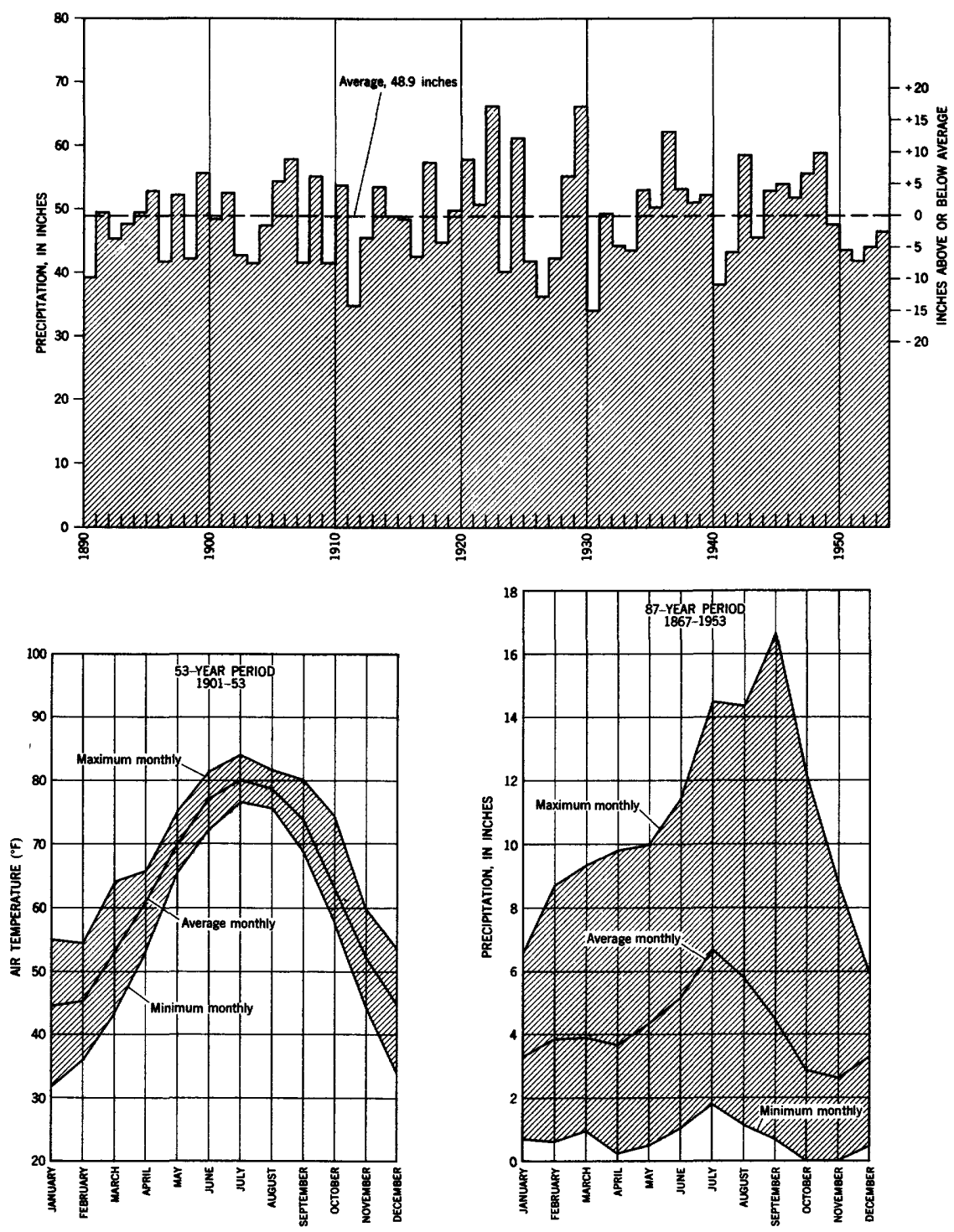

Figure 2. -Precipitation and air temperature at Goldsboro, N. C. (U. S. Weather Bureau data).

\section{NATURAL RESOURCES}

The most widely used natural resources of the Neuse River basin in addition to water are its soils and forests, but mineral production and fisheries are important at some places. 

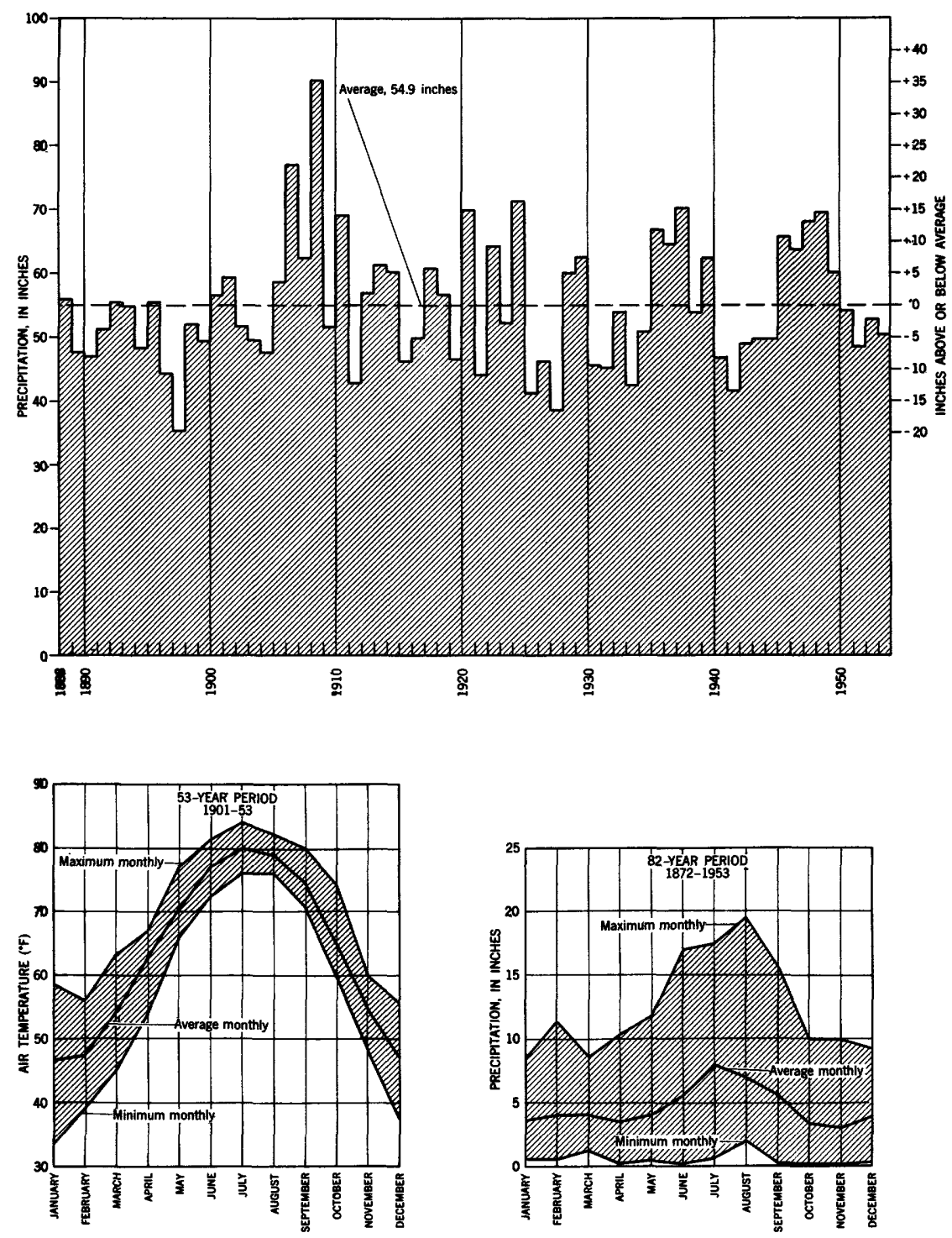

Figure 3. - Precipitation and air temperature at New Bern, N. C. (U. S. Weather Bureau data).

The soils of the Piedmont and upper Coastal Plain are chiefly red and yellow sandy loams, sandy clay loams, and silt loams. In the lower Coastal Plain, the soils are also sandy loams or silt loams but are generally poorly drained soils, low in humus content. An area of "hard pan" is found southeast from Kinston and bog soils are common in places where muck and peat have accumulated. 
The Neuse River basin is rich in forest resources, the climate and topography being suitable for the growth of a great variety of trees which may be used for lumber and furniture making and the production of pulpwood and cellulose. The loblolly pine is the most important tree for both lumber and pulpwood, but several other pines and many hardwoods are abundant.

In the Piedmont the chief mineral product is crushed and dimension stone, mainly granite, but lesser quantities of heavy clay materials and pyrophyllite are extracted. In the Coastal Plain the mining of sand, gravel, and marl are important.

In the lower counties of the basin, salt-water fisheries are an important resource. The principal fish caught here is the menhaden which is processed into oil, fishmeal, and other products. Foodfish, principally alewives, shrimps, and crabs are supplied to inland markets.

\section{AGRICULTURAL AND INDUSTRIAL DEVELOPMENT}

The Neuse River basin is primarily an agricultural region, tobacco being the chief dollar crop in all counties. In the Piedmont, other important crops are corn, hay, wheat, and potatoes, with cotton becoming more important nearer the Coastal Plain. Other crops in the Coastal Plain are corn, cotton, and potatoes, with potatoes assuming greater importance near the coast. Dairying and beef cattle production are important in both areas. The crops occupying the greatest acreage are corn, cotton, and tobacco, in that order.

There is some industrial diversification in the basin but the chief industries are textiles and lumbering. The manufacture of cigarettes and other tobacco products is concentrated at Durham. Other important industries include the processing of food and other agricultural products, the making of furniture and other wood products, the production of synthetic fiber, and the manufacture of various agricultural and consumer products.

The many small towns and the few cities are important commercial centers. The usual commercial enterprises are well represented in the basin but the most colorful, and one of the most important, is that of buying and selling tobacco at the many warehouses and markets throughout the basin.

Several railroads serve the area but the extensive network of all-weather roads has made trucking animportant means of transport. The cities of Raleigh, Durham, Kinston, New Bern, and 
Morehead City have airline service and water transportation is important near the coast through the Intracoastal Waterway and the deep-water port at Morehead City.

\section{DEFINITION OF TERMS}

The records for quantities of water are expressed in various terms in the presentation of hydrologic data. Some of these terms have become associated with certain types of works and may be divided into two general groups: those that represent a rate of flow such as million gallons per day (mgd), gallons per minute (gpm), cubic feet per second (cfs), million gallons per day per square mile, and cubic feet per second per square mile (cfsm); and those that represent volume of water, as million gallons, million gallons per square mile, and as runoff depth in inches on the drainage basin.

The gallon is the volumetric unit commonly used in North Carolina in connection with pumping rates, storage for water supplies and sprinkler-type irrigation systems, whereas the cubic foot is the volumetric unit generally used in connection with power generation and with flood flows.

The units in which hydrologic data are given in this report may be defined as follows:

A cubic foot per second is the rate of discharge equivalent to that of a stream whose channel is 1 square foot in cross-sectional area and whose average velocity is 1 foot per second.

A million gallons per day per square mile is defined as 1 million gallons of water per day flowing from each square mile of area drained, on the assumption that runoff is distributed uniformly as regards time and area.

Cubic feet per second per square mile is the average number of cubic feet of water per second flowing from each square mile of area drained, on the assumption that the runoff is distributed uniformly as regards time and area.

$$
\begin{aligned}
& 1 \mathrm{cfs}=448.8 \mathrm{gpm}=0.646 \mathrm{mgd} \\
& 1 \mathrm{mgd}=1.55 \mathrm{cfs}=694.4 \mathrm{gpm}
\end{aligned}
$$

$A$ water-year begins October 1 and ends September 30 and is the year for which most streamflow data are reported. The water-year is used in analysis and presentation of data on low flow in this report except that magnitude and frequency of low flows are based on a climatic-year beginning April 1 and ending March 31. 
One part per million (ppm) is a unit weight of a constituent in a million unit weights of water. In the chemical analysis of water samples, it is necessary to determine the presence of various substances usually found in minute amounts; therefore, the results are usually expressed in parts per million rather than in percentages. One part per million equals one ten-thousandth of one percent (0.0001 percent).

The hydrogen-ion concentration in an aqueous solution or water is represented on the $\mathrm{pH}$ scale by a number which is the negative logarithm of the hydrogen-ion concentration in moles per liter. A solution having a pH value of 7.0 is neutral, that is, it is neither acid or alkaline. Progressive $\mathrm{pH}$ values below 7.0 denote increasing acidity and progressive $\mathrm{pH}$ values above 7.0 denote increasing alkalinity.

Specific conductance is a measure of the ability of a water to conduct an electrical current and is expressed in micromhos at a temperature of $25^{\circ} \mathrm{C}$. It varies with the concentration and degree of ionization of the different minerals in solution and with the temperature. The conductance, however, does not indicate the relative quantities of different salts in solution.

\section{OCCURRENCE AND QUALITY OF WATER}

\section{THE HYDROLOGIC CYCLE}

The water we use, whether it is from surface or ground water sources, has its origin in precipitation. In the natural sequence of events, the water that is evaporated from the oceans by the energy of the sun is carried inland as water vapor and falls on the land from clouds as rain, snow, sleet, or hail. Some of the precipitation is returned to the atmosphere by evaporation and transpiration but the remainder percolates into the ground or flows overland in surface streams. That water which moves beneath or upon the land surface eventually reaches the sea where it may again be evaporated. This recurring succession of events is known as the hydrologic cycle.

It is evident that, although the quantity of water involved in the hydrologic cycle remains rather constant for the earth as a whole, the amount of water available from any specific source varies with precipitation from time to time or from place to place. Because of this natural circulation, water may be regarded as a renewable resource.

Rainfall that reaches the ground and does not evaporate or run off seeps downward, moving through the minute spaces between 
soil particles. Much of this water is held in the soil to be used by trees, crops, and other vegetation. Soil moisture requirements have a priority on precipitation and a large percentage of rainfall, especially during the growing season, is used by vegetation.

When the rate of precipitation exceeds the rate of absorption in the ground, surplus water infiltrates further downward to a zone which it saturates. The water in this zone of saturation is called ground water; as it slowly percolates to lower elevations, it discharges into surface channels from seeps and springs to maintain streamflow in dry weather or discharges into the sea.

When precipitation exceeds the rate at which it can be absorbed in the ground, water must flow on the surface, where it develops channels or gullies in the land in its search for drainage ways. Surface runoff may be stored in ponds or other reservoirs to minimize flood damage and to provide water during periods of deficiency that may follow. If water levels are higher in streams than in the surrounding rock formations, some water may enter into and recharge the ground-water reservoir.

Water can be utilized best by man when in lakes and streams or underground reservoirs. Water constantly passes from one part of the hydrologic cycle to another, appearing as a gas in the atmosphere, as a liquid in surface or ground-water bodies, or as a solid when frozen. If $m$ an is to evaluate his water resources and rationally plan their use, continuing investigations must be made not only by geologists and hydrologists but also by meteorologists, agronomists, and other technical personnel.

\section{SOURCES OF WATER}

Both surface and ground water sources are utilized in the Neuse River basin.

In the Piedmont section of the basin, the yield of wells is not very great, being rarely as much as $100 \mathrm{gpm}$ and usually much less. Water supplies for large cities such as Durham and Raleigh must necessarily come from surface streams. Large mills or other industrial plants must also obtain most of their water from lakes or streams, either by constructing their own facilities or by purchasing treated water from a public supply. Several small towns in the Piedmont section have wells to furnish their public supplies but no large city in that area has ever used ground water.

In the Coastal Plain, ground-water sources are more important than in the Piedmont. Wells yielding more than 200 to $300 \mathrm{gpm}$ 
are common. Because of the low relief over much of the coastal plain, the construction of large dams for water supplies or other purposes is not generally possible and only one public supply, that for Goldsboro, is obtained from surface water. Large public, industrial, and irrigation supplies may be obtained from groundwater sources. It may be said that, generally, large water supplies are obtained from surface sources in the Piedmont section but from wells in the Coastal Plain.

Of the cities and towns in the Neuse River basin that have public water supplies, 77 percent, serving 120,000 persons, use ground water, and 23 percent, serving 240,000 persons, have surfacewater sources (see pl. 3). Ground water is used for domestic supplies by 62 percent of the basin's population.

\section{SIGNIFICANCE OF QUALTTY OF WATER}

An adequate water supply is a determining factor in the selection of an industrial site. Sharing importance with quantity is a knowledge of the chemical quality, degree of pollution, and a seasonal estimate of suspended sediment carried by the stream.

Chemical analyses of water for municipal or industrial uses are necessary to determine whether the water is suitable for specific purposes, and, if not, to determine the type and cost of the treatment needed to make it satisfactory. The analyses aid in determining the suitability of the water for drinking, steam production and heating, manufacturing, laundering, or other uses. Comprehensive analyses can also be used to determine the cost of softening water, its scale-forming properties and its tendency to corrode plumbing.

The chemical requirements for water used by different industries are so variable that it is impossible to establish specifications to fit all uses. In general, however, most industries require clear water low in total mineral content and hardness. Water temperature is also an important factor in determining the value of water for industrial use. The requirements of chemical quality of water for various industrial processes are given in table 1.

Generally accepted chemical specifications have been established for waters used domestically; they are independent of any sanitary specifications established for protection of the public 
Table 1.-Water quality tolerances for industrial applications

[American Water Works Association, 1950, Water quality and treatment, p. 67, table 3-4. Remarks: A, no corrosiveness; $B$, no slime formation; $C$, conformance to Federal drinking-water standards; $\mathrm{D}, \mathrm{Al}_{2} \mathrm{O}_{3}$ less than $8 \mathrm{ppm}$. $\mathrm{SiO}_{2}$ less than $25 \mathrm{ppm}, \mathrm{Cu}$ less than $5 \mathrm{ppm}$. Chemical constituents in parts per million]

\begin{tabular}{|c|c|c|c|c|c|c|c|c|c|c|}
\hline Industrial use & $\begin{array}{r}\text { Tur- } \\
\text { bidity }\end{array}$ & Color & $\mathbf{F e}$ & $M n$ & $\begin{array}{l}\mathrm{Fe} \\
+\mathrm{Mn}\end{array}$ & $\begin{array}{c}\text { Hard- } \\
\text { ness }\end{array}$ & $\begin{array}{l}\text { Alka - } \\
\text { linity }\end{array}$ & $\mathrm{pH}$ & $\begin{array}{l}\text { Total } \\
\text { solids }\end{array}$ & $\begin{array}{l}\text { Gen- } \\
\text { eral }\end{array}$ \\
\hline 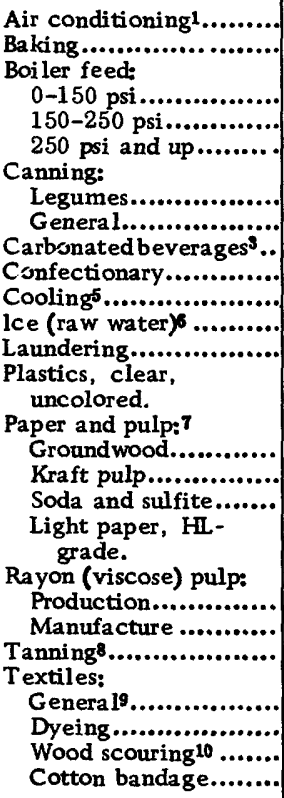 & $\mid \begin{array}{c}\ldots \ldots \\
10 \\
20 \\
10 \\
5 \\
10 \\
10 \\
2 \\
\cdots \ldots . . \\
50 \\
1-5 \\
\cdots \ldots . . \\
2\end{array}$ & 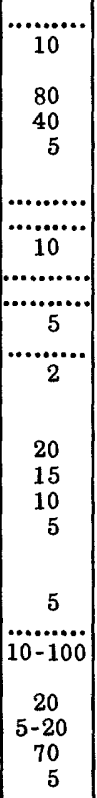 & $\mid \begin{array}{c}\cdots . . . \\
\cdots \ldots . . \\
\cdots \ldots . . \\
.2 \\
.2 \\
.2 \\
.2 \\
.5 \\
.2 \\
.2 \\
.02\end{array}$ & $\begin{array}{c}.03 \\
.0 \\
.2 \\
.25 \\
.25 \\
1.0 \\
.2\end{array}$ & $\begin{array}{l}.2 \\
.2 \\
.3 \\
.2 \\
.5 \\
.2 \\
.2 \\
.02\end{array}$ & $\begin{array}{c}\ldots \ldots \\
(2) \\
75 \\
40 \\
8 \\
25-75 \\
\cdots \ldots . . . \\
250 \\
\ldots \ldots . . . \\
50 \\
\ldots \ldots . . . \\
50 \\
\ldots \ldots . . .\end{array}$ & 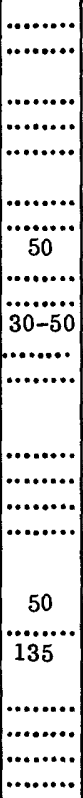 & 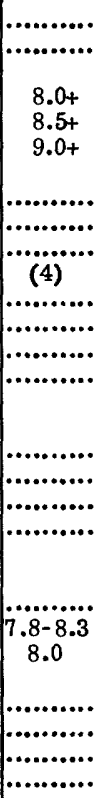 & 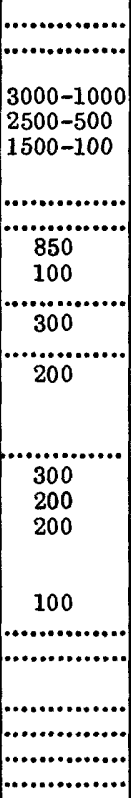 & $\begin{array}{c}C \\
C \\
C \\
A, B \\
C\end{array}$ \\
\hline
\end{tabular}

1 Waters with algae and hydrogen sulfide odors are most unsuitable for air conditioning.

2 Some hardness desirable.

3 Clear, odorless, sterile water for syrup and carbonation. Water consistent in character. Most high-quality filtered municipal water not satisfactory for beverages.

1 Hard candy requires $\mathrm{pH}$ of 7.0 or greater, as low value favors inversion of sucrose, causing sticky product.

5 Control of corrosion is necessary as is also control of organisms, such as sulfur and iron bacteria, which tend to form slimes.

$6 \mathrm{Ca}\left(\mathrm{HCO}_{3}\right)_{2}$ particularly troublesome. $\mathrm{Mg}\left(\mathrm{HCO}_{3}\right)_{2}$ tends to greenish color. $\mathrm{CO}_{2}$ assists to prevent cracking. Sulfates and chlorides of $\mathrm{Ca}, \mathrm{Mg}, \mathrm{Na}$ should each be less than 300 ppm (white butts)

7 Uniformity of composition and temperature desirable. Iron objectionable since cellulose adsorbs iron from dilute solutions. Manganese very objectionable, clogs pipelines and is oxidized to permanganates by chlorine, causing reddish color.

8 Excessive iron, manganese, or turbidity creates spots and discoloration in tanning of hides and leather goods.

9 Constant composition; residual alumina $<0.5 \mathrm{ppm}$.

10 Calcium, magnesium, iron, manganese, suspended matter and soluble organic matter may be objectionable. 
health. In 1946 the United States Public Health Service established chemical and physical specifications for drinking water used on interstate carriers as follows:

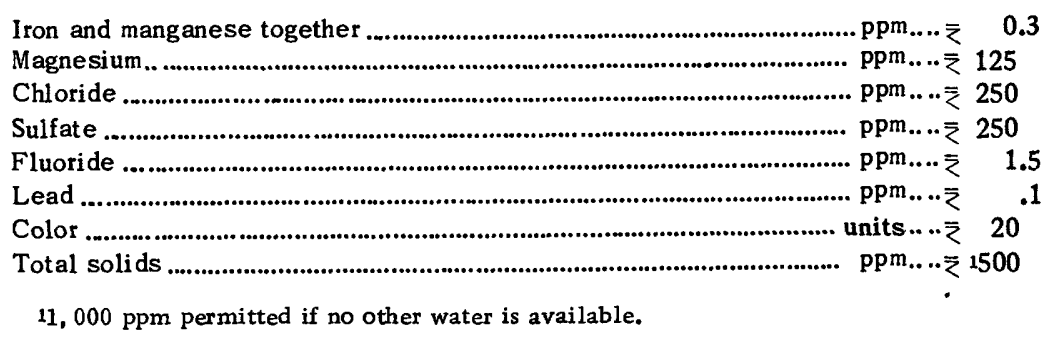

The above specifications have since been adopted by the American Water Works Association and most municipalities as standard for public water supplies. Water containing less than $500 \mathrm{ppm}$ of dissolved solids generally is satisfactory for most domestic and industrial uses. However, an excessive iron content or hardness may cause difficulty in some uses. Waters containing more than $1,000 \mathrm{ppm}$ of dissolved solids are likely to include certain constituents that make them unsuitable for domestic or industrial uses.

Information on hardness of water is of great importance. In domestic use hardness is recognized by the difficulty in obtaining a lather without an excessive consumption of soap; the insoluble, sticky curd that results in washing processes using soap, and the scale formed in vessels in which the water is boiled. Industry gives much attention to hardness in water supplies because it affects manufacturing processes and the finished product. Furthermore the scale deposited in hot-water pipes, hot-water heaters, and steam boilers, results in economic loss through loss of heat transfer, increased fuel consumption, and breakdown of equipment. Calcium and magnesium are the principal causes of hardness. Other constituents, such as iron, manganese, aluminum, barium, strontium, and free acid also cause hardness but generally they are not present in sufficient quantities to have an appreciable effect on the hardness. Water having a hardness of less than 60 ppm is usually rated as soft and suitable for most purposes. Hardness ranging between 60 and $120 \mathrm{ppm}$ may be considered moderate, but it does not seriously interfere with the use of the water except in high pressure steam boilers and in some industrial processes. Water having a hardness ranging from 121 to $200 \mathrm{ppm}$ is hard, and, in the upper ranges, laundries and industries may profitably soften the supply. Waters having a hardness greater than $200 \mathrm{ppm}$ is usually softened before being used.

Iron and manganese in excess of $0.3 \mathrm{ppm}$ are objectionable for several reason. Excessive amounts of iron and manganese cause 
reddish-brown stains on white porcelain or enamelware, on fixtures, and on clothing or other fabrics. These two constituents in excessive amounts, interfere with dyeing, tanning, paper manufacturing, and the manufacture of photographic film and many other products.

Color, in water analysis, refers to the appearance of water that is free of suspended material. Generally waters are colored by or ganic matter leached from plants, tree roots, and organic components of soils. Highly colored waters may foam in boilers and can stain processed products. It is more difficult to remove iron and to soften the water with hot phosphate solutions in highly colored waters than in clear water. Also, color is objectionable in public water supplies for esthetic reasons.

\section{SURFACE WATER}

During North Carolina's history, the Neuse River has played an important part in the development of the region. From the time of the early settlements when New Bern was the colonial capital, the river was the artery upon which ships traveled inland. As shipping diminished, the River and its tributaries supplied power in the operation of grist and saw mills, and water for municipal and industrial use, generation of electric power, recreation, and other uses. At New Bern the Neuse River drains an area of 5,040 square miles including the Trent River area.

The rivers and creeks are valuable assets, but at times they can become liabilities. There have been occasions when streamflow was inadequate to meet the established requirements of many users in the basin. At still other times floods have menaced extensive areas, particularly in the lower reaches.

Streamflow information consists of continuous records of flow at gaging stations on the rivers and smaller streams and of periodic and occasional measurements of flow at other sites. At present, 14 gaging stations are operated within the basin, some having been maintained since 1925 (see fig. 4). On many small streams where no continuous records of flow are available, measurements of streamflow have been made during periods of low flow to supply a more complete coverage of the area. Records of daily flow and results of miscellaneous measurements are published in annual water-supply papers of the U. S. Geological Survey. Gaging sites at which continuous records of flow are not collected are known as partial-record stations. Locations of complete-record gaging stations and partial-record stations are shown on plate 1 and pertinent descriptive data are given in table 2. 


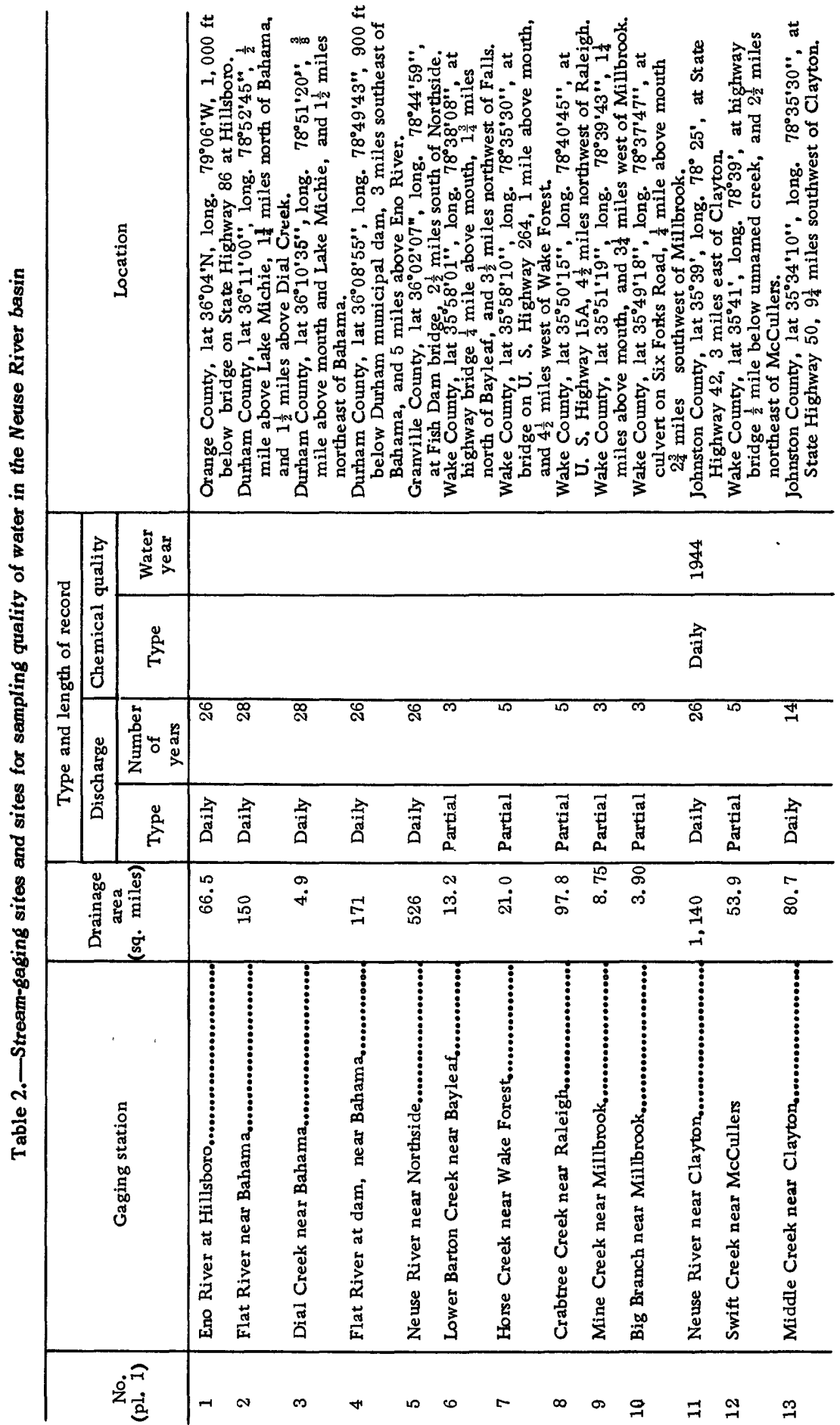




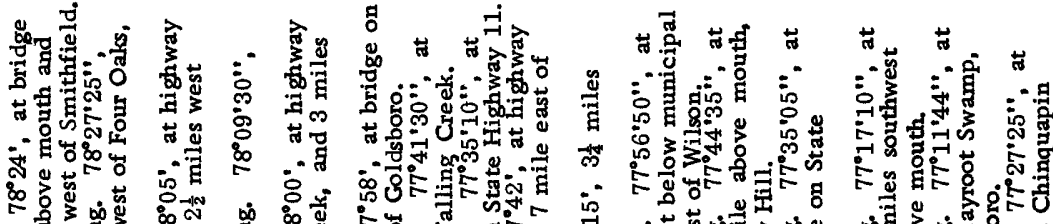
का

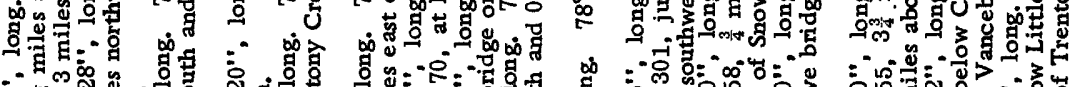

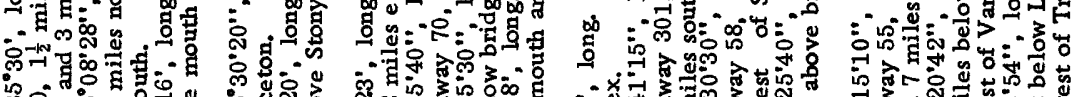

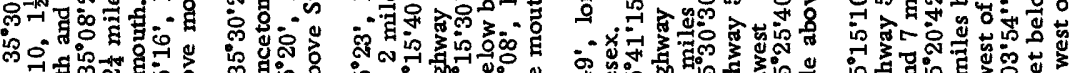

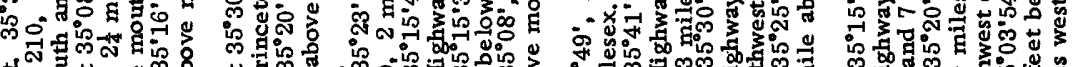

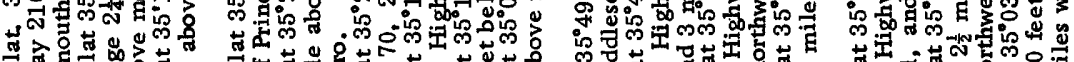

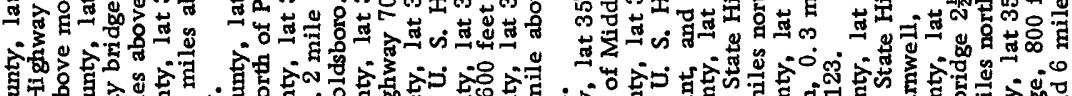

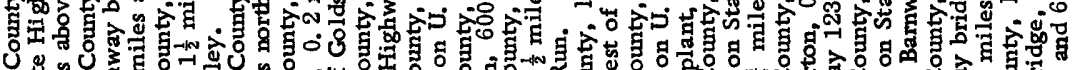

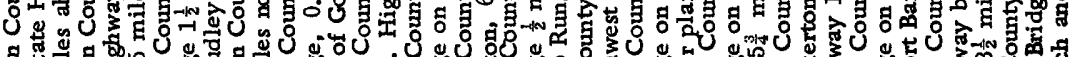

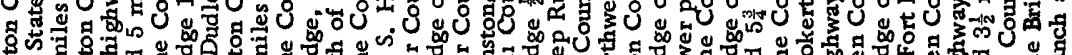

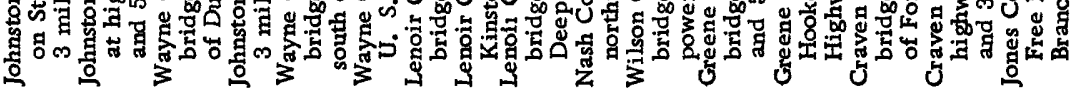

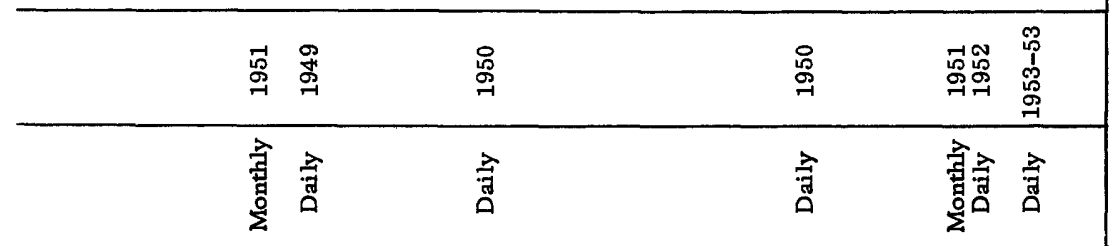

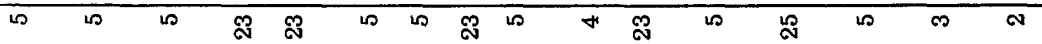

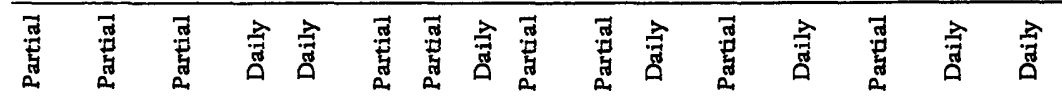

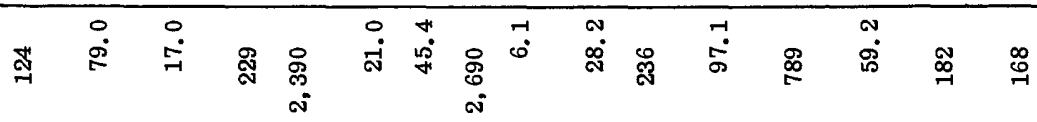

\begin{tabular}{|c|c|c|c|c|c|c|c|c|c|c|c|c|c|c|c|}
\hline 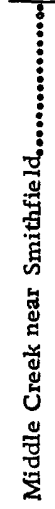 & 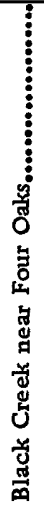 & 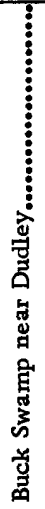 & 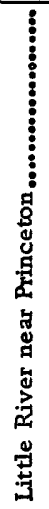 & 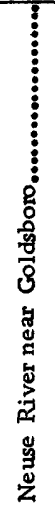 & 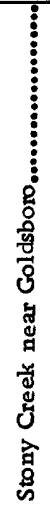 & 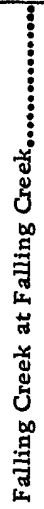 & 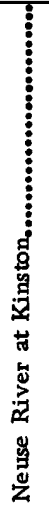 & 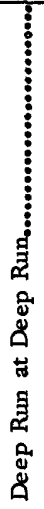 & 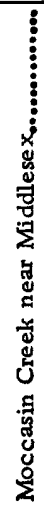 & $\begin{array}{l}\vdots \\
\vdots \\
\vdots \\
0\end{array}$ & 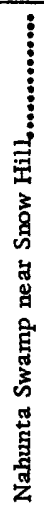 & 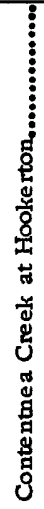 & 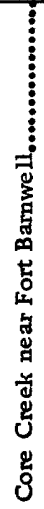 & 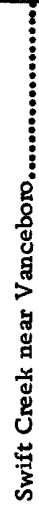 & $\begin{array}{c} \\
\vdots \\
\vdots\end{array}$ \\
\hline
\end{tabular}

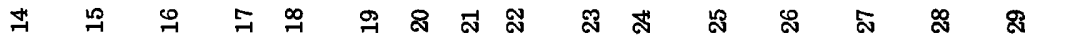




\begin{tabular}{|c|c|c|c|c|c|c|c|c|}
\hline \multirow{2}{*}{ 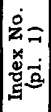 } & \multirow[b]{2}{*}{ ભ } & \multicolumn{6}{|c|}{ Water years ending September 30} & \multirow{2}{*}{ Gaging station } \\
\hline & & 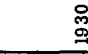 & 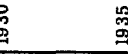 & & 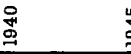 & $\stackrel{\text { }}{9}$ & 㿣 & \\
\hline 1 & & 200 & & & & & 40000 & Eno River at Hillsboro \\
\hline 2 & & & & 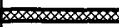 & 00000000 & 00000000000000 & 10000000 & Flat River at Bahama \\
\hline 3 & & 0000000 & $\infty \infty$ & 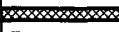 & & & & Dial Creek near Bahama \\
\hline 4 & & $\infty$ & & & & & & Flat River at dam, near Bahama \\
\hline 5 & & 000 & & 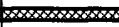 & 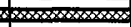 & 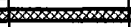 & 1000000082 & Neuse River near Northside \\
\hline ll & & $080800 \times 8 \times 4$ & 85858805808 & 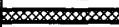 & 20588080800 & 28080858008088 & 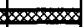 & Neuse River near Clayton \\
\hline 13 & & & & 2 & 8 & 200808080020002 & $\infty$ & Middle Creek near Clayton \\
\hline 17 & & . & & & 2080 & 5000000000000 & 10000000 & Little River near Princeton \\
\hline 18 & & $\infty$ & & & & & 20008000 & Neuse River near Goldsboro \\
\hline 21 & & 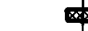 & & & & & 20 & Neuse River at Kinston \\
\hline 24 & & 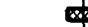 & 08088080808580 & $\infty$ & & & $80 x \operatorname{ses} 8$ & Contentnea Creek near Wilson \\
\hline 26 & & 0000 & & & & & 00000 & Contentnea Creek at Hookerton \\
\hline 28 & & & & & & $\approx$ & & Swift Creek near Vanceboro \\
\hline 29 & & & & & & & 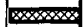 & Trent River near Trenton \\
\hline
\end{tabular}

Figure 4. -Duration of records at gaging stations in the Neuse River basin.

In evaluating and comparing the flow characteristics of streams it is advantageous to have these characteristics computed for a common period of record, often called the base period. In this report the period October 1, 1927 to September 30, 1953 (water years 1928-53) was selected as the base period. This base period was chosen because several records beginning in 1927 were available for use in a regional analysis and because the records subsequent to September 30,1953, had not been computed in final form at the time the report was being prepared. Some of the more noteworthy floods and droughts occurred during the base period, but on many streams the flow during the 1954 drought was lower than at any time during the base period. However, comparison with earlier records that are available at a few stations indicate that in general the average flow during the base period was less than during the period 1896 to 1954 .

In general the flow of the streams in the Neuse River basin is affected little by the control works of man. Among the exceptions are the effects of Lake Michie on Flat River and a storage reservoir on Contentnea Creek. The flow of Flat River below Lake Michie is regulated by operation of the hydroelectric plant and by diversion of water for the city of Durham. Waste water from Durham is discharged into the Cape Fear River basin and into the Neuse River below Flat River. The flow of Contentnea Creek is regulated by operation of the hydroelectric plant and by diversion of water for the city of Wilson.

The designer of hydraulic works must consider the variations in streamflow. Water shortages generally occur only at times 
when stream runoff is considerably below normal and they are often mistakenly referred to as drought shortages when they really should be described as resulting from inadequate planning or from increased demands outrunning the expansion of facilities.

The data presented within this report generally will be adequate for preliminary planning. In order to conserve space much of the data is given in tabular form. However, a few sample graphs have been given to illustrate differences in characteristics of streams. The reader will be able to plot additional curves as needed, perhaps by adding them to the graphs that have been given. The data presented for partial-record stations and at short-term gaging stations are obtained from relationships with other stations and therefore cannot be considered as reliable as information from the long-term gaging stations. The data presented for partialrecord stations will not take the place of detailed studies necessary for hydraulic works. Care should be exercised in using the "per square mile" data even on the same streams because all parts of most drainage areas do not have similar runoff characteristics or equal yields per unit of area. In general, the possible error increases with an increase in distance between the gaging station and the place where information on flow is desired.

In appraising the adequacy of a specific source for water supply, the requirements will be known for water consumption or for waste disposal. To meet these requirements the percent of time the flow is sufficient to meet the needs must be determined. Information is also required on how frequently the flow will be insufficient, how long the deficiency will persist, and what storage will be required to meet the deficiency. This report has been designed to provide data that will serve as a guide in preliminary planning to meet these requirements.

\section{FLOW CHARACTERISTICS}

Streamflow varies greatly from day to day, season to season, and from year to year. (See fig. 22). The long-term average streamflow per unit of area, however, is relatively uniform over the entire Neuse River basin. No significant long-term trend toward either an increase or decrease in the annual flow has been discovered during the period of record. In the Neuse River basin the average streamflow is approximately uniform per unit area ( $0.65 \mathrm{mgd}$ per square mile) for streams in the rocky Piedmont as well as for those in the sandy Coastal Plain. The high and low flow of streams in these two areas, however, reflect differences in rainfall, topography, geology, vegetation, size of drainage area, and other factors. 
Curves showing streamflow characteristics are usually prepared for the period of record at the gaging site under study; however, these curves can be adjusted to longer periods by statistical methods using records on nearby streams. It is also possible to make a regional analysis of the data by statistical methods. A regional analysis is a study to make the best possible evaluation of the flow characteristics of a stream by taking into consideration records from nearby streams. Streamflow data in this report are generally for the base period, October 1, 1927 to September 30, 1953 and a regional analysis has been made of the low-flow frequency data. Where the period of record is significantly different from the base period, curves for both periods may be shown, as in figure 7. Data for stations with only short periods of record were extended to the base period, where practicable. For sites where only partial records of discharge were obtained (see table 2 ), data were computed for the base period by correlation with data from nearby gaging sites.

The precipitation during the base period was about normal (figs. 1 to 3 , and therefore, the streamflow was probably about normal. Assuming that future flow will follow the pattern of flow measured in the past, curves showing the flow characteristics during the base period maybe used to estimate the probable occurrence of a specified discharge.

\section{DURATION OF FLOW}

A duration curve of daily flow shows the percentage of time that a specified daily flow was equaled or exceeded. It shows the cumulative frequency of occurrence of different rates of flow at a given point. Flow-duration curves for four representative gaging stations in the basin are given in figures 5 to 7 . Flow-duration data and average discharge for all sites are given in table 3.

The slope of a duration curve is a good index of the natural storage within a basin, including ground-water storage; that is, the flatter the general slope of the curve the more uniform the flow. Streams are said to have a well-sustained flow if the flow per square mile during dry weather is greater than usually found over a large area. A comparison of flow-duration curves for several streams in the basin shows which streams have the best sustained flow. Figures 6 to 9 show that the lower part of the curve for the Neuse River near Clayton is the highest of the four and, therefore, indicates the best sustained flow. The curve for Little River near Princeton shows somewhat better sustained flow than those for the two other stations illustrated. 


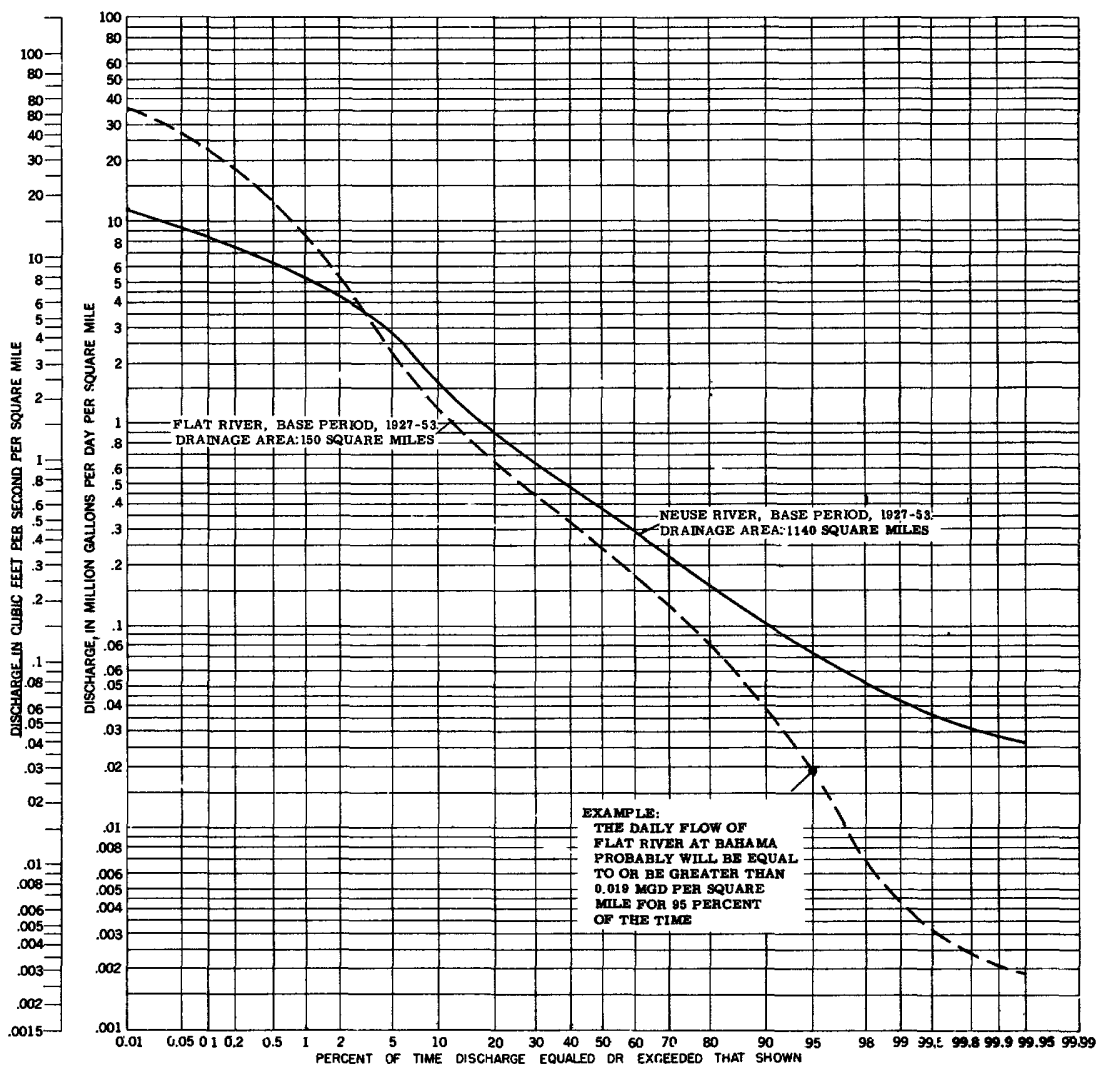

Figure 5.-Duration curve of daily flow, Flat River at Bahama and Neuse River near Clayton, N. C.

As an example of the further use of flow-duration.curves, assume that it is desired to locate an industrial plant on a site. adjacent to Middle Creek at which the drainage area is 100 square miles and that construction of a storage dam is not planned. Further assume that a flow of $2.5 \mathrm{mgd}(0.025 \mathrm{mgd}$ per square mile from 100 square miles) is required for plant operation. Inasmuch as the observed minimum flows are less than the required flow, it is necessary to know the probable number of days per year that there will be a shortage of water. From the curve for the base period 1928-53 (fig. 6), a flow of $0.025 \mathrm{mgd}$ per square mile will be available 98 percent of the time assuming that the flow in the future will be similar to that during the base period. Thus over a long period of time there will be sufficient water 98 percent of the 


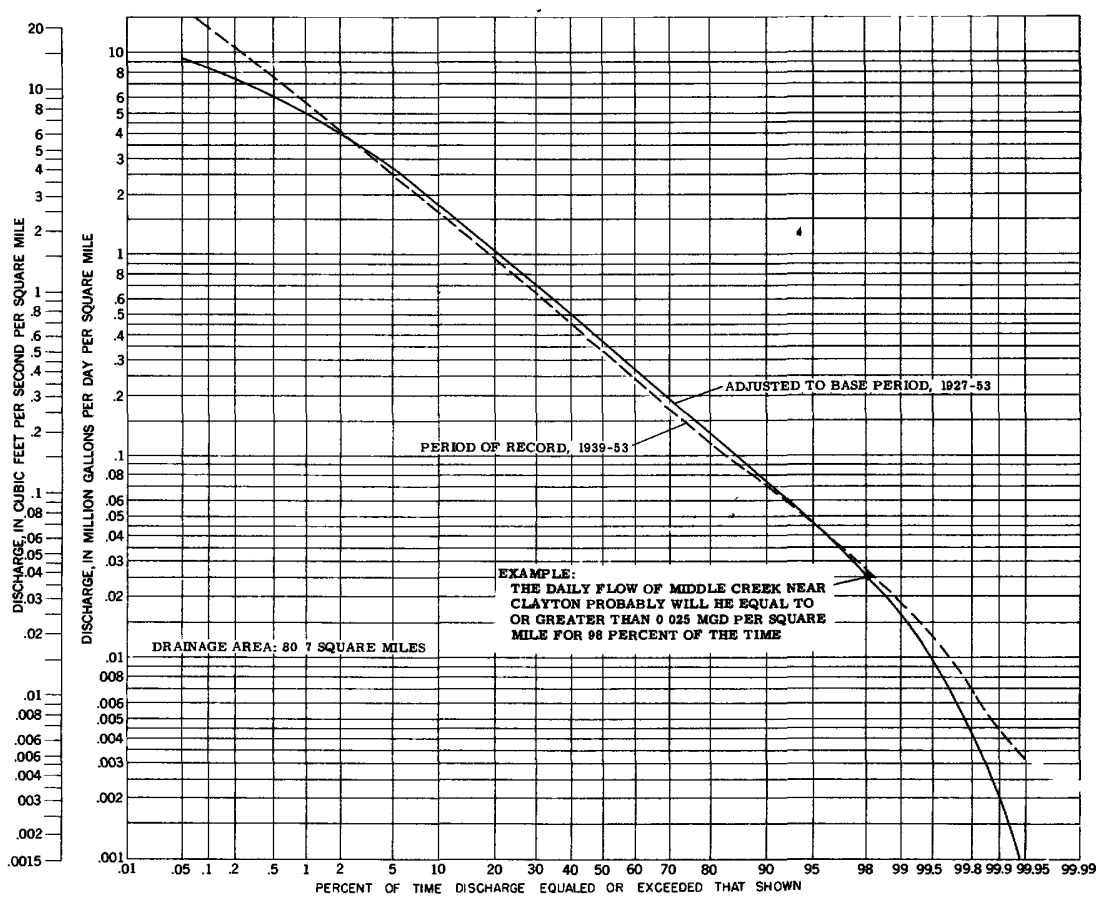

Figure 6. -Duration curve of daily flow, Middle Creek near Clayton, N. C.

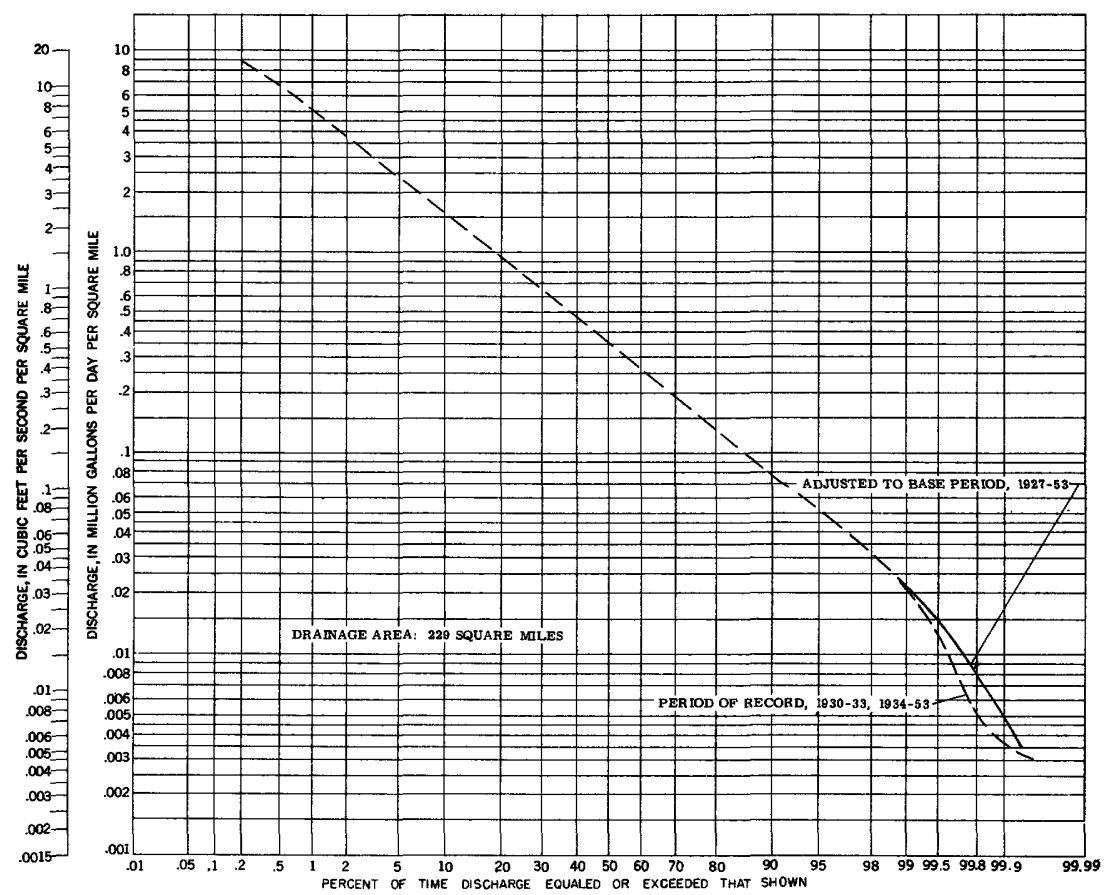

Figure 7.-Duration curve of daily flow, Little River near Princeton, N. C. 
Table 3.-Duration of daily flow in the Neuse River basin, 1928-53

\begin{tabular}{|c|c|c|c|c|c|c|}
\hline & \multicolumn{6}{|c|}{$\begin{array}{c}\text { Flow, in million gallons per day per square mile, which was exceeded or } \\
\text { equaled for indicated percent of time }\end{array}$} \\
\hline & $\begin{array}{l}\text { 1. Eno } \\
\text { River } \\
\text { at } \\
\text { Hillsboro }\end{array}$ & $\begin{array}{l}\text { 2. Flat } \\
\text { River } \\
\text { at } \\
\text { Bahama }\end{array}$ & $\begin{array}{l}\text { 3. Dial } \\
\text { Creek } \\
\text { near } \\
\text { Bahama }\end{array}$ & $\begin{array}{l}\text { 4. Flat } \\
\text { River } \\
\text { at } \\
\text { dam, } \\
\text { near } \\
\text { Bahama }\end{array}$ & \begin{tabular}{|l} 
5. Neuse \\
River \\
near \\
Northside
\end{tabular} & $\begin{array}{l}\text { 6. Lower } \\
\text { Barton } \\
\text { Creek } \\
\text { near } \\
\text { Bayleaf }\end{array}$ \\
\hline $\begin{array}{l}\text { Drainage area } \\
\text { sq miles.. }\end{array}$ & 66.5 & 150 & 4.9 & 171 & 526 & 13.2 \\
\hline \multirow[t]{3}{*}{ 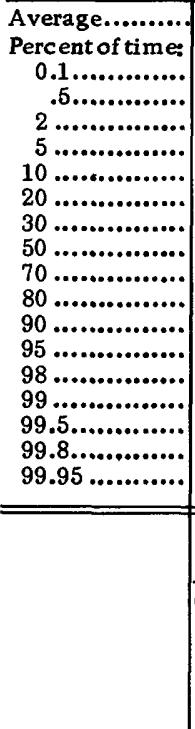 } & $\begin{array}{c}0.638 \\
23.3 \\
9.82 \\
4.42 \\
2.13 \\
1.21 \\
.690 \\
.486 \\
.282 \\
.167 \\
.188 \\
.063 \\
.040 \\
.022 \\
.0082 \\
.0052 \\
.0039 \\
.0027\end{array}$ & \begin{tabular}{|c|}
0.629 \\
22.4 \\
12.7 \\
5.30 \\
2.26 \\
1.21 \\
.646 \\
.444 \\
.241 \\
.125 \\
.081 \\
.038 \\
.019 \\
.0069 \\
.0042 \\
.0031 \\
.0023 \\
.0018
\end{tabular} & 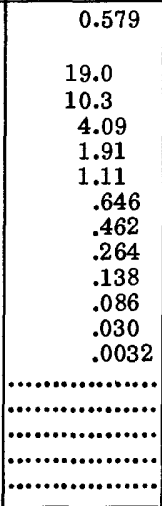 & 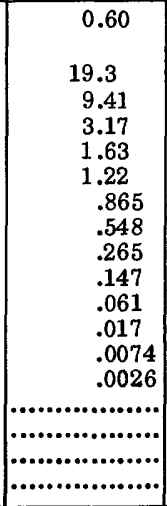 & $\begin{array}{c}0.66 \\
17.1 \\
9.09 \\
4.40 \\
2.36 \\
1.45 \\
.811 \\
.547 \\
.289 \\
.150 \\
.100 \\
.046 \\
.023 \\
.013 \\
.0098 \\
.0079 \\
.0060 \\
.0046\end{array}$ & 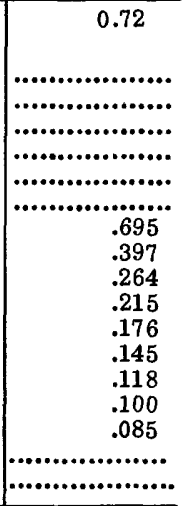 \\
\hline & \multicolumn{6}{|c|}{$\begin{array}{c}\text { Flow, in million gallons per day per square mile, which was exceeded or } \\
\text { equaled for indicated percent of time }\end{array}$} \\
\hline & $\begin{array}{l}\text { T. Horse } \\
\text { Creek } \\
\text { near } \\
\text { Wake } \\
\text { Forest }\end{array}$ & $\begin{array}{l}\text { 8. Crabtree } \\
\text { Creek } \\
\text { near } \\
\text { Raleigh }\end{array}$ & $\begin{array}{l}\text { 9. Mine } \\
\text { Creek } \\
\text { near } \\
\text { Millbrook }\end{array}$ & $\begin{array}{l}\text { 10. Big } \\
\text { Branch } \\
\text { near } \\
\text { Millbrook }\end{array}$ & $\begin{array}{l}\text { 11. Neuse } \\
\text { River } \\
\text { near } \\
\text { Clayton }\end{array}$ & $\begin{array}{l}\text { 12. Swift } \\
\text { Creek } \\
\text { near } \\
\text { McCullers }\end{array}$ \\
\hline $\begin{array}{r}\text { Drainage } \\
\text { sq } n\end{array}$ & 21.0 & 97.8 & 8.7 & 3.9 & 1,140 & 53.9 \\
\hline 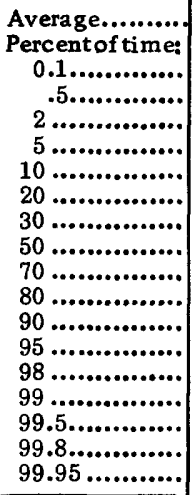 & 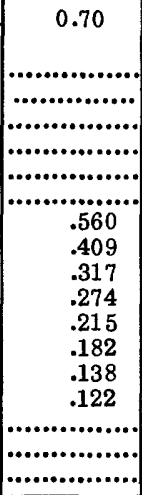 & 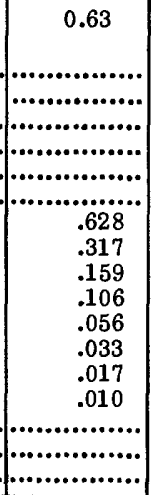 & 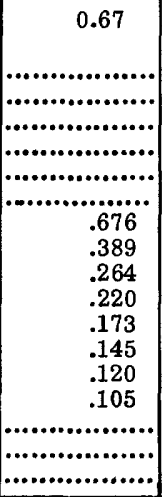 & 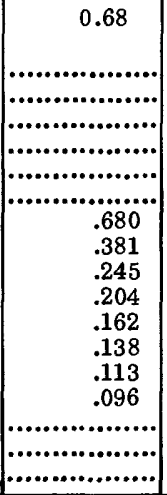 & $\begin{array}{l}0.696 \\
8.33 \\
6.07 \\
4.20 \\
2.78 \\
1.67 \\
.884 \\
.612 \\
.380 \\
.230 \\
.164 \\
.105 \\
.074 \\
.053 \\
.044 \\
.037 \\
.032 \\
\ldots . . . \ldots . .\end{array}$ & 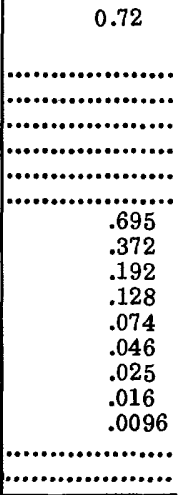 \\
\hline
\end{tabular}

${ }^{2}$ Period of record (1927-53) unadjusted for regulation by Lake Michie and power plant or for diverson to city of Durham for municipal water supply. 
Table 3.-Duration of daily flow in the Neuse River basin, 1928-53-Continued

\begin{tabular}{|c|c|c|c|c|c|c|}
\hline & \multicolumn{6}{|c|}{$\begin{array}{c}\text { Flow, in million gallons per day per square mile, which was exceeded or } \\
\text { equaled for indicated percent of time }\end{array}$} \\
\hline & $\begin{array}{l}\text { 13. Middle } \\
\text { Cr eek } \\
\text { near } \\
\text { Clayton }\end{array}$ & $\begin{array}{l}\text { 14. Middle } \\
\text { Creek } \\
\text { near } \\
\text { Smithfield }\end{array}$ & $\begin{array}{l}\text { 15. Black } \\
\text { Creek } \\
\text { near } \\
\text { Four } \\
\text { Oaks }\end{array}$ & $\begin{array}{c}\text { 16. Buck } \\
\text { Swamp } \\
\text { near } \\
\text { Dudley }\end{array}$ & $\begin{array}{l}\text { 17. Little } \\
\text { River } \\
\text { near } \\
\text { Princeton }\end{array}$ & $\begin{array}{l}\text { 18. Neuse } \\
\text { River } \\
\text { near } \\
\text { Goldsboro }\end{array}$ \\
\hline $\begin{array}{r}\text { Drainage } \\
\text { sq } \mathrm{m}\end{array}$ & 80.7 & 124 & 79.0 & 17.0 & 229 & 2,390 \\
\hline 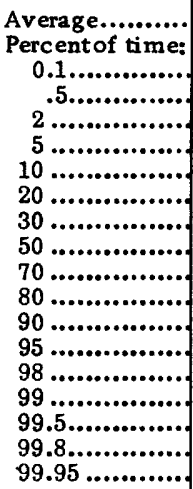 & $\begin{array}{l}0.729 \\
8.17 \\
6.09 \\
4.04 \\
2.72 \\
1.76 \\
1.04 \\
.705 \\
.376 \\
.192 \\
.128 \\
.074 \\
.046 \\
.025 \\
.016 \\
.0096 \\
.0043 \\
.00080\end{array}$ & 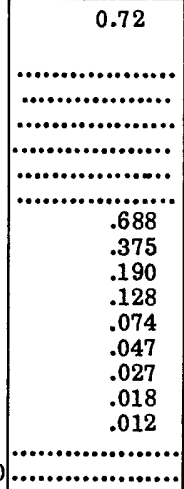 & 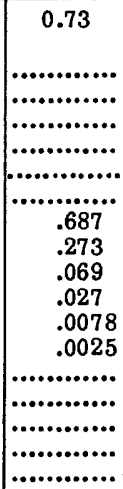 & 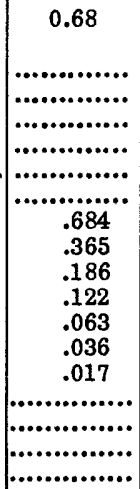 & \begin{tabular}{|c|c} 
& 0.677 \\
& \\
$\ldots \ldots \ldots \ldots \ldots$ \\
6.74 \\
3.87 \\
2.43 \\
1.64 \\
.988 \\
.677 \\
.373 \\
.206 \\
.144 \\
.083 \\
.053 \\
.030 \\
.019 \\
.011 \\
.0048 \\
.0032
\end{tabular} & $\begin{array}{c}\ldots \ldots \ldots \ldots \\
0.73 \\
1.65 \\
.865 \\
.595 \\
.373 \\
.227 \\
.162 \\
.103 \\
.070 \\
.051 \\
.042 \\
.035 \\
.030 \\
.024\end{array}$ \\
\hline
\end{tabular}

Flow, in million gallons per day per square mile, which was exceeded or equaled for indicated percent of time

\begin{tabular}{|c|c|c|c|c|c|c|}
\hline & $\begin{array}{l}\text { 19. Stony } \\
\text { Creek } \\
\text { at } \\
\text { Goldsboro }\end{array}$ & $\begin{array}{l}\text { 20. Falling } \\
\text { Creek } \\
\text { at } \\
\text { Falling } \\
\text { Creek }\end{array}$ & $\begin{array}{l}\text { 21. Neuse } \\
\text { River } \\
\text { at } \\
\text { Kinston }\end{array}$ & $\begin{array}{l}\text { 22. Deep } \\
\text { Rum } \\
\text { at } \\
\text { Deep } \\
\text { Rum } \\
\end{array}$ & $\begin{array}{l}\text { 23. Moccasin } \\
\text { Creek } \\
\text { near } \\
\text { Middlesex }\end{array}$ & $\begin{array}{l}\text { 24. Contentnea } \\
\text { Creek } \\
\text { near } \\
\text { Wilson } b\end{array}$ \\
\hline $\begin{array}{r}\text { Drainage ar } \\
\text { sq mi }\end{array}$ & 21.0 & 45.4 & 2,690 & 6.1 & 28.2 & 236 \\
\hline 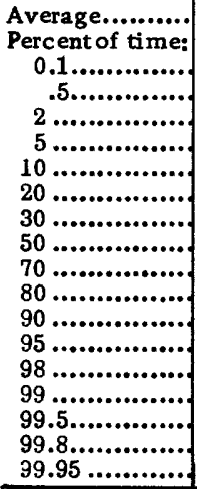 & 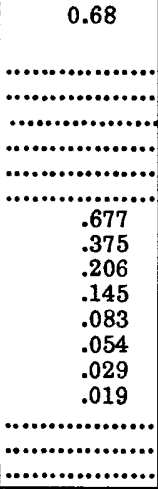 & 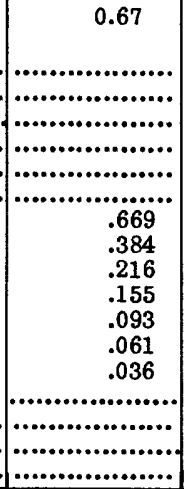 & \begin{tabular}{|c} 
\\
\\
$\ldots .674$ \\
$\ldots \ldots \ldots \ldots . .$. \\
$\ldots \ldots \ldots \ldots$ \\
2.81 \\
1.68 \\
.889 \\
.625 \\
.408 \\
.259 \\
.190 \\
.125 \\
.089 \\
.065 \\
.054 \\
.047 \\
.041 \\
.034
\end{tabular} & 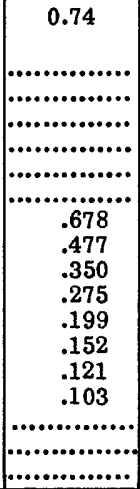 & 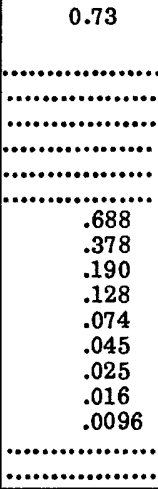 & 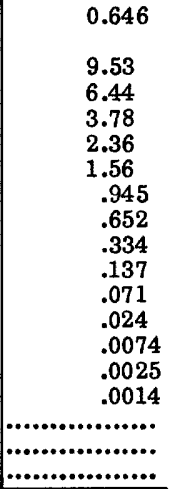 \\
\hline
\end{tabular}

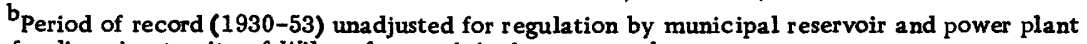
or for diversion to city of Wilson for municipal water supply. 
Table 3.-Duration of daily flow in the Neuse River basin, 1928-53-Continued

\begin{tabular}{|c|c|c|c|c|c|}
\hline & \multicolumn{5}{|c|}{$\begin{array}{c}\text { Flow, in million gallons per day per square mile, which was exceeded or } \\
\text { equaled for indicated percent of time }\end{array}$} \\
\hline & $\begin{array}{l}\text { 25. Nahunta } \\
\text { Swamp } \\
\text { near } \\
\text { Snow } \\
\text { Hill }\end{array}$ & $\begin{array}{l}\text { 26. Contentnea } \\
\text { Creek } \\
\text { at } \\
\text { Hookerton }\end{array}$ & $\begin{array}{l}\text { 27. Core } \\
\text { Creek } \\
\text { near } \\
\text { Fort } \\
\text { Barnwell }\end{array}$ & $\begin{array}{l}\text { 28. Swift } \\
\text { Creek } \\
\text { near } \\
\text { Vanceboro }\end{array}$ & $\begin{array}{l}\text { 29. Trent } \\
\text { River } \\
\text { near } \\
\text { Trenton }\end{array}$ \\
\hline $\begin{array}{l}\text { Drainage area } \\
\text { sq miles.. }\end{array}$ & 97.1 & 789 & 59.2 & 182 & 168 \\
\hline 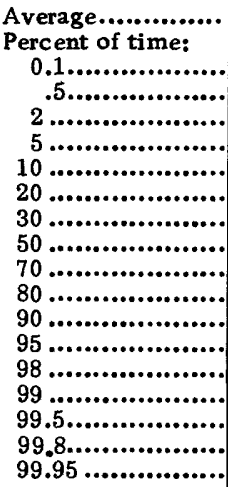 & 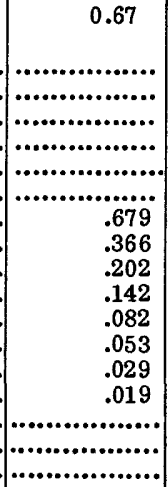 & 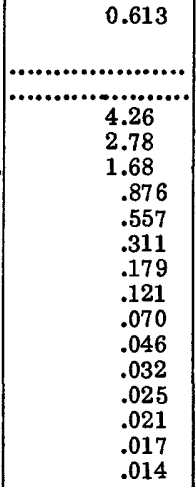 & 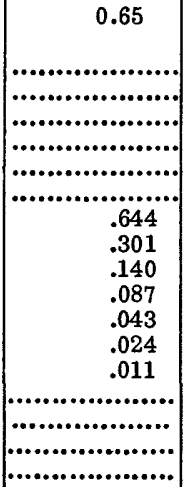 & 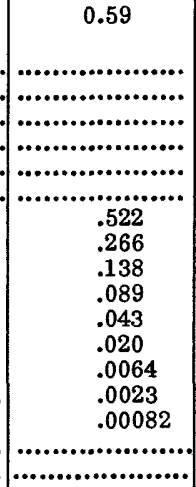 & 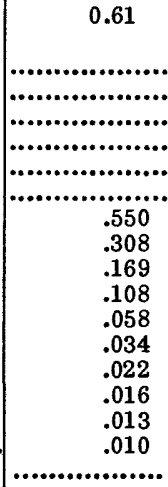 \\
\hline
\end{tabular}

days and a shortage on 2 percent of the days. The advantages of the proposed site where a water shortage will occur 2 percent of the time could be weighed with alternate sites farther downstream (larger drainage areas) or sites on other streams where the required flow will be available a greater portion of the time.

The flow-duration curve does not show whether the days of insufficient flow will be consecutive or how frequently shortages will occur. It may be possible to operate the plant for short periods on less than $2.5 \mathrm{mgd}$ or if not, possibly the plant can be shut down occasionally if the shortage does not occur too frequently. Therefore we need to know more about the low-flow characteristics of the stream. How frequently will the flow be insufficient? How long will deficiencies last? How much storage will be required to provide the necessary flow? These questions may be answered by use of the low-flow frequency curve, curve for the maximum period of deficient discharge, and the storage-requirement curve.

\section{LOW-FLOW FREQUENCY}

The low-flow frequency curve gives the average interval at which a specific discharge may be expected to recur as the lowest flow 


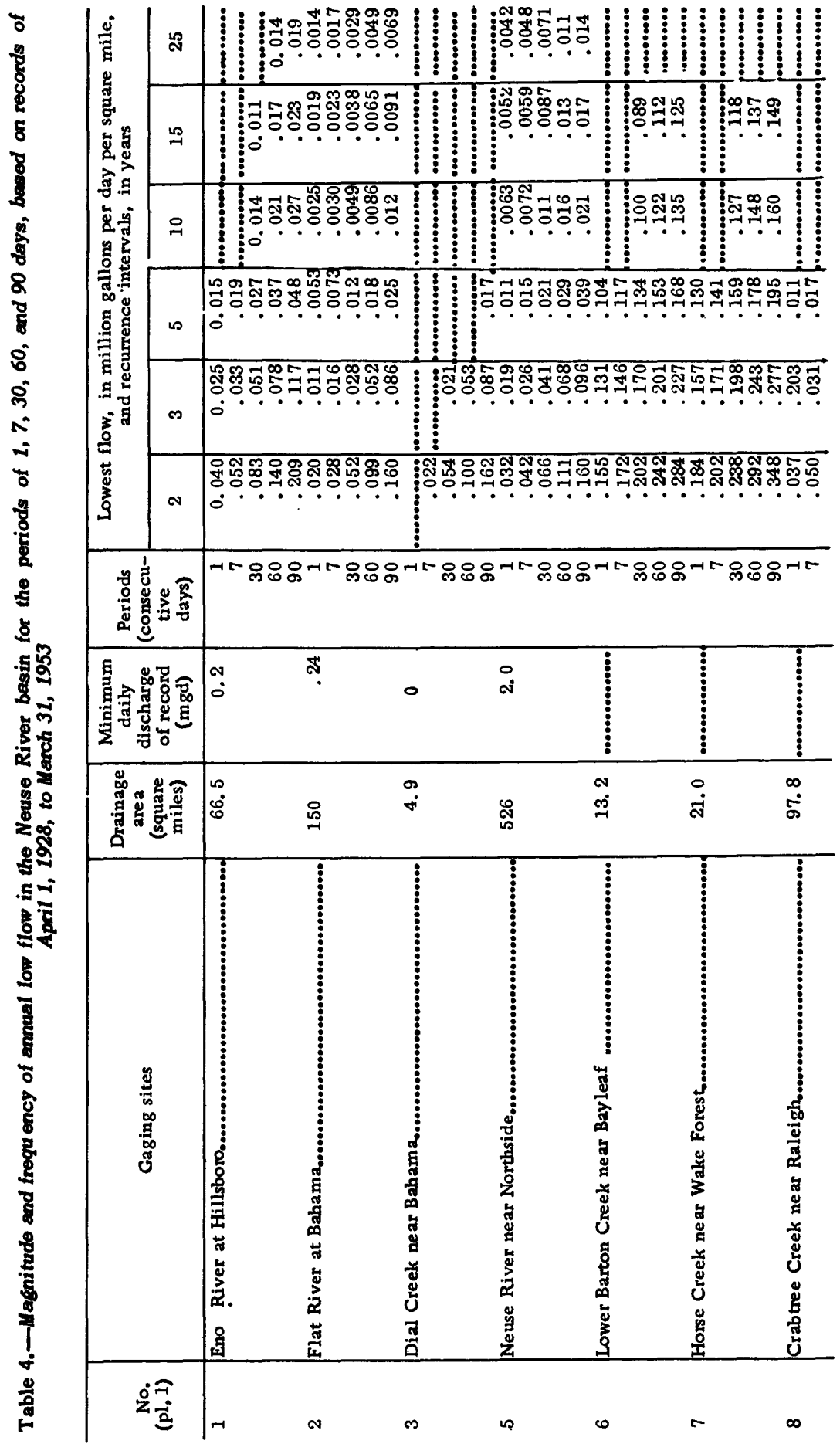




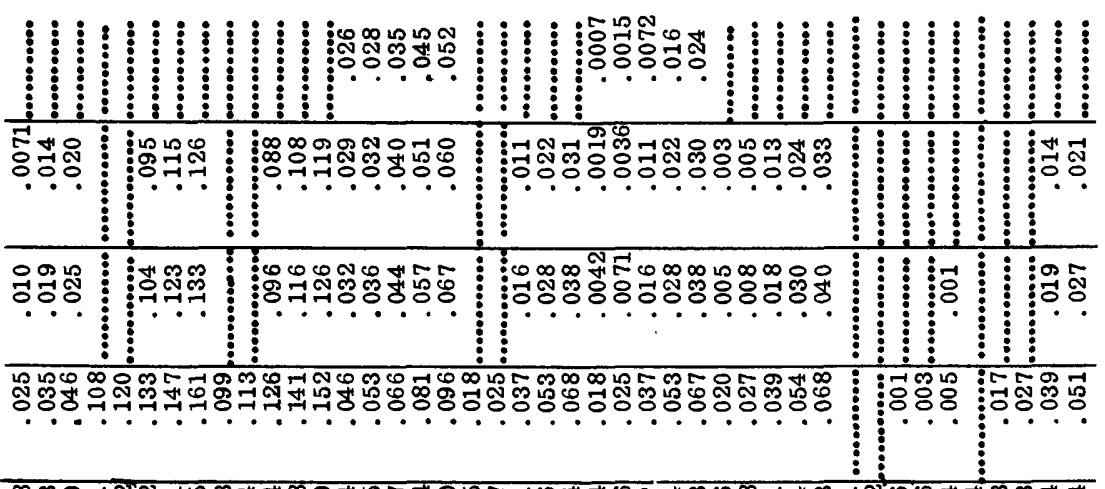

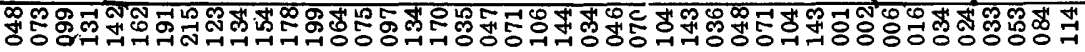

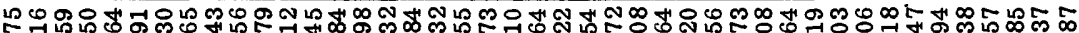

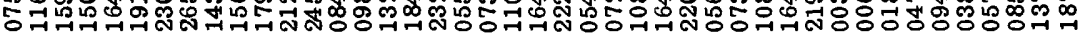

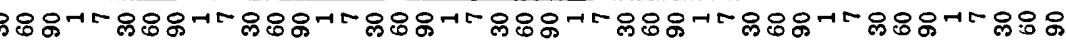

\begin{tabular}{|c|c|c|c|c|c|c|c|}
\hline $\begin{array}{l}\vdots \\
\vdots \\
\vdots \\
\vdots\end{array}$ & $\begin{array}{l}: \\
\vdots \\
\vdots \\
\vdots\end{array}$ & g্ডে & $\begin{array}{l}\vdots \\
\vdots \\
\vdots\end{array}$ & $\because$ & $\begin{array}{l}\vdots \\
\vdots \\
\vdots\end{array}$ & $:$ & $\begin{array}{l}0: \\
\vdots \\
\vdots \\
\vdots\end{array}$ \\
\hline $\begin{array}{l}\infty \\
\infty \\
\infty\end{array}$ & $\begin{array}{l}\text { ᄋ } \\
\text { ம }\end{array}$ & 峦 & $\begin{array}{l}\text { क } \\
\text { ஜ் }\end{array}$ & ¿ & $\underset{\mathrm{J}}{\mathrm{J}}$ & $\stackrel{\circ}{\circ}$ & $\stackrel{0}{-1}$ \\
\hline
\end{tabular}

\begin{tabular}{|c|c|c|c|c|c|c|c|}
\hline $\begin{array}{c}\vdots \\
\vdots \\
\vdots \\
\vdots \\
\vdots \\
\vdots \\
\vdots \\
\vdots\end{array}$ & $\begin{array}{c}\vdots \\
\vdots \\
\vdots \\
\vdots \\
\vdots \\
\vdots \\
\vdots \\
\vdots\end{array}$ & $\begin{array}{c}\vdots \\
\vdots \\
\vdots \\
\vdots \\
\vdots \\
\vdots \\
\vdots \\
\vdots \\
\vdots\end{array}$ & $\begin{array}{c}\vdots \\
\vdots \\
\vdots \\
\vdots \\
\vdots \\
\vdots \\
\vdots \\
\vdots \\
\vdots\end{array}$ & 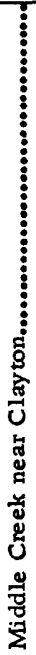 & $\begin{array}{c}\vdots \\
\vdots \\
\vdots \\
\vdots \\
\vdots \\
\vdots \\
\vdots \\
\vdots \\
0\end{array}$ & $\begin{array}{c}\vdots \\
\vdots \\
\vdots \\
\vdots \\
\vdots \\
\vdots \\
\vdots \\
\vdots \\
\vdots\end{array}$ & 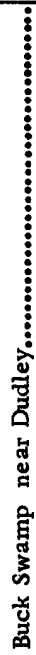 \\
\hline
\end{tabular}

$\infty$

$\underset{-1}{0}$

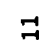

c

$\infty$

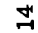

눈

$\stackrel{\infty}{\sim}$ 
WATER RESOURCES, NEUSE RIVER BASIN, NORTH CAROLINA

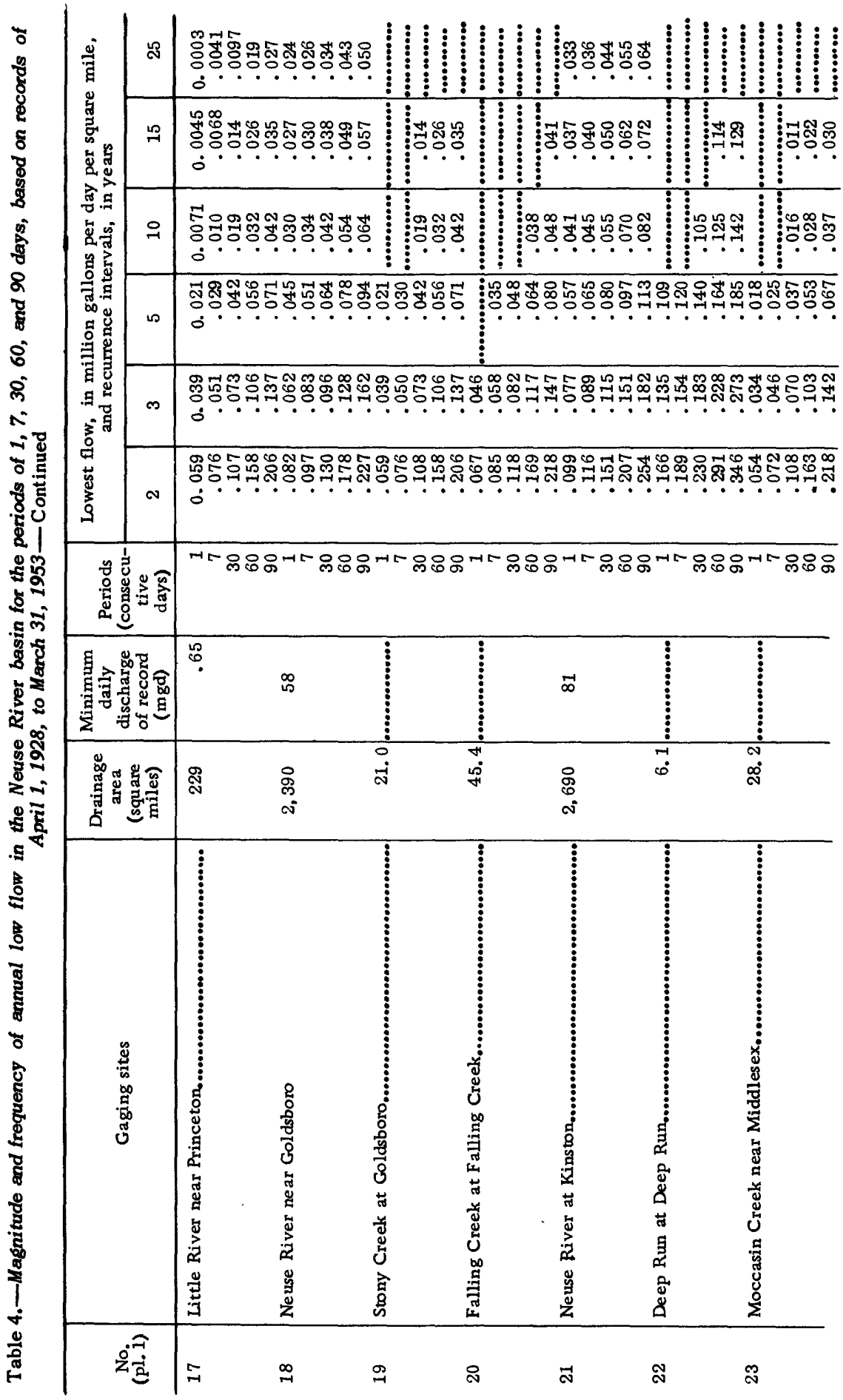




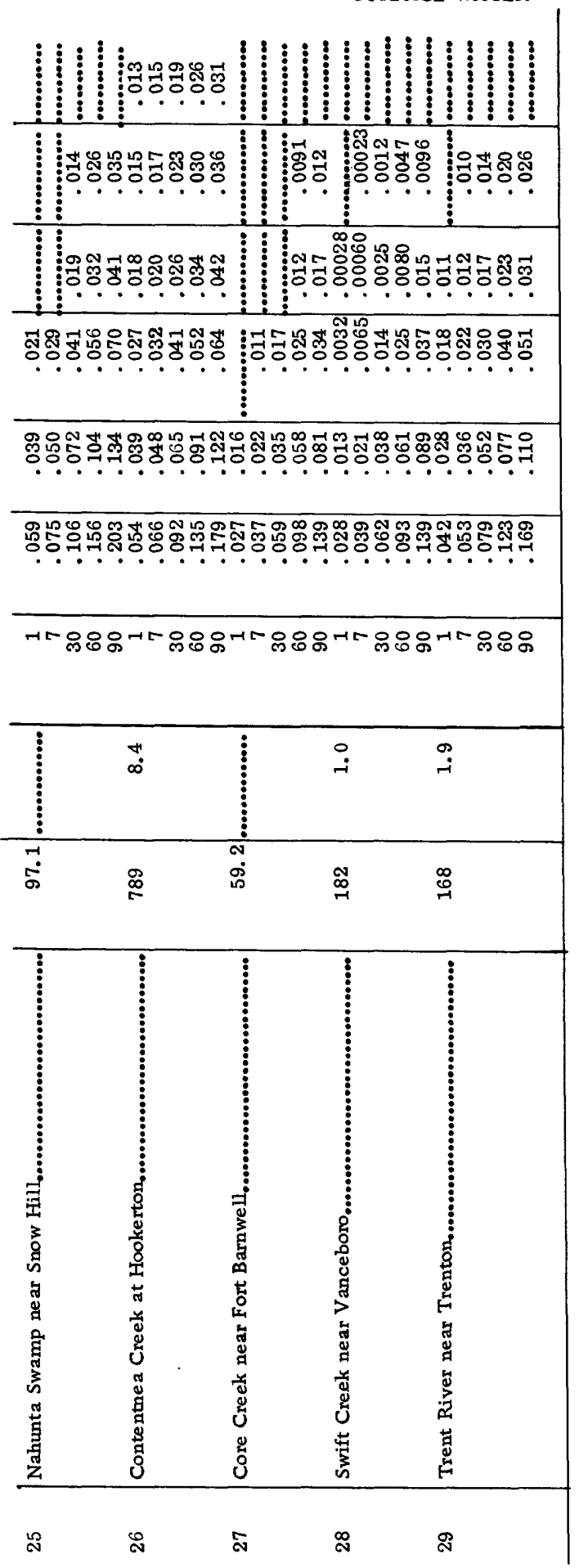


Table 5ـLowest flow for 7 consecutive days in each year in Neuse River basin, 1925 -52

[Million gallons per day]

\begin{tabular}{|c|c|c|c|c|c|c|c|c|c|c|c|c|}
\hline \multirow[b]{2}{*}{$\begin{array}{c}\text { Year } \\
\text { (beginning } \\
\text { April 1) }\end{array}$} & \multicolumn{12}{|c|}{ Gaging station and No. (pl.1) } \\
\hline & 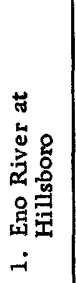 & 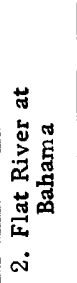 & 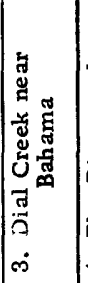 & 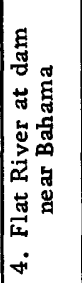 & 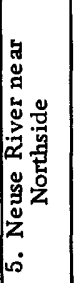 & 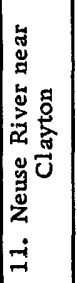 & 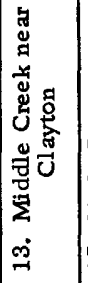 & 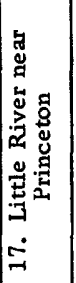 & 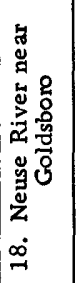 & 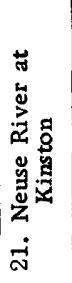 & 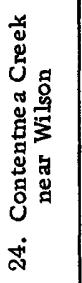 & 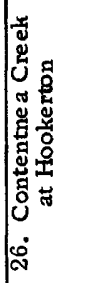 \\
\hline & & 0.43 & 0.28 & $\cdots$ & & & & - & $\bullet$ & & & \\
\hline 192 & (n........ & $\begin{array}{l}1.3 \\
6.1\end{array}$ & .03 & $\because 0.54$ & 28 & $\ddot{130 \ddot{~}}$ & 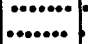 & (n)........ & $\ldots$ & (........ & & •......... \\
\hline $\begin{array}{l}1928 \\
1928\end{array}$ & $\begin{array}{r}4.2 \\
8.6\end{array}$ & $\begin{array}{c}4.6 \\
15\end{array}$ & $\begin{array}{l}.16 \\
.63\end{array}$ & $29^{.30}$ & $\begin{array}{l}22 \\
70\end{array}$ & $\begin{array}{r}91 \\
277\end{array}$ & $\ldots . . . .0$ & $\ldots . . . .$. & ......... & 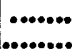 & co. & $\ddot{210}$ \\
\hline 103 & 2.1 & 1.1 & & .45 & 7.6 & 69 & $\ldots$ & 5 & iï6 & 200 & 1.0 & 43 \\
\hline 193. & 2.5 & 2.3 & .0 & 78 & 12 & 101 & $\ldots \ldots$ & 13 & 186 & 244 & 7.2 & 49 \\
\hline 1932 & .9 & .27 & & 59 & 2.4 & 34 & & & 64 & 92 & . 1 & 9.3 \\
\hline & 1.0 & .36 & 0 & & 4.1 & 34 & ......... & 9 & 92 & 123 & . 1 & 12 \\
\hline & 7.0 & 10 & 26 & 21 & 60 & 165 & b....... & 23 & 283 & 426 & 18 & 81 \\
\hline 1935 & 2.7 & 4.2 & 13 & 2.3 & 16 & 96 & & 16 & 180 & 348 & 6.1 & 71 \\
\hline & 5.5 & 6.4 & & 2.4 & 34 & 169 & $\ldots . . . .$. & 18 & 310 & 487 & 8.7 & 79 \\
\hline & 11.0 & & , 44 & 15 & 55 & 239 & 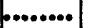 & 30 & 478 & 512 & 14 & 66 \\
\hline & 7.0 & & 46 & 0 & 21 & 131 &. & 24 & 353 & 488 & 16 & 70 \\
\hline & 8.8 & 9.7 & 70 & 16 & 51 & 190 & & 26 & 333 & 443 & 15 & 88 \\
\hline & 3.0 & 5.9 & 18 & 2.8 & 22 & 97 & 1.7 & 12 & 163 & 236 & 8.0 & 43 \\
\hline & .2 & 59 & & 1.4 & 4.3 & 39 & 2.3 & 2 & 69 & 114 & & 23 \\
\hline & 3.8 & 8.6 & .19 & 2.3 & 28 & 128 & 6.5 & 9 & 200 & 311 & & 34 \\
\hline & 1.7 & .83 & & .19 & 4.9 & 54 & 6.7 & 7 & 127 & 202 & 1.3 & 30 \\
\hline & 2.9 & 2.1 & & 1.8 & 15 & 68 & 4. & 11 & 123 & 200 & 2.4 & 29 \\
\hline & 5.4 & 14 & .34 & 5.0 & 46 & 128 & 4.9 & 14 & 274 & 372 & 20 & 66 \\
\hline & 4.2 & 3.8 & 14 & 5.2 & 24 & 153 & 7.4 & 20 & 313 & 468 & 12 & 76 \\
\hline & 2.9 & 5.8 & 25 & 5.4 & 18 & 106 & 5.3 & 15 & 259 & 353 & 8.6 & 59 \\
\hline & 2.6 & 4.5 & & 6.5 & 23 & 85 & 1.1 & 13 & 167 & 205 & 1.0 & 30 \\
\hline & 6.3 & 9.9 & 43 & 5.8 & 41 & 184 & 13 & 34 & 458 & 571 & 19 & 106 \\
\hline & 4.2 & 6.8 & 32 & 4.1 & 36 & 120 & 4.6 & 17 & 253 & 347 & 13 & 68 \\
\hline & 1.4 & 1.7 & & 1.9 & 10 & 50 & .6 & 5 & 83 & 141 & .3 & 17 \\
\hline & 5.6 & 11 & .13 & 6.3 & 22 & 74 & 2.1 & 13 & 162 & 141 & 7 & 32 \\
\hline
\end{tabular}

in the climatic year (April 1 to March 31 ). Low-flow frequency curves for the average flow during periods of $1,7,30,60$, and 90 consecutive days are shown in figure 8 to 11 . These curves do not imply a regularity of occurrence but rather the probable average interval between specified low flows. Assuming that the flow during the period April 1928 to March 1953 was normal and that future flow will follow the pattern of flow measured in the past, these curves may be used to predict future streamflow. For example, on Neuse River near Clayton the lowest daily flow in a year may be expected to be equal to or less than $0.046 \mathrm{mgd}$ per square mile at an average interval of 5 years, or a total of 20 times in 100 years (fig. 9). The magnitude and frequency of low flows for the various periods for all gaging sites are shown in table 4.

The pattern of low flow in many streams becomes irregular in the lower reaches of the stream owing to regulation of the 
discharge upstream. The regulation frequently causes a period of very low flow of short duration within a longer period of relatively uniform flow. The minimum daily flow of these streams is often considered too limiting as a measure of the flow characteristics for many uses of the water. Where the regulation is minor and when it occurs in uniform weekly patterns, the average 7-day flow is a better indication of the flow characteristics of the stream. The lowest average 7-day flow for each year of record at gaging stations in the Neuse River basin is shown in table 5 .

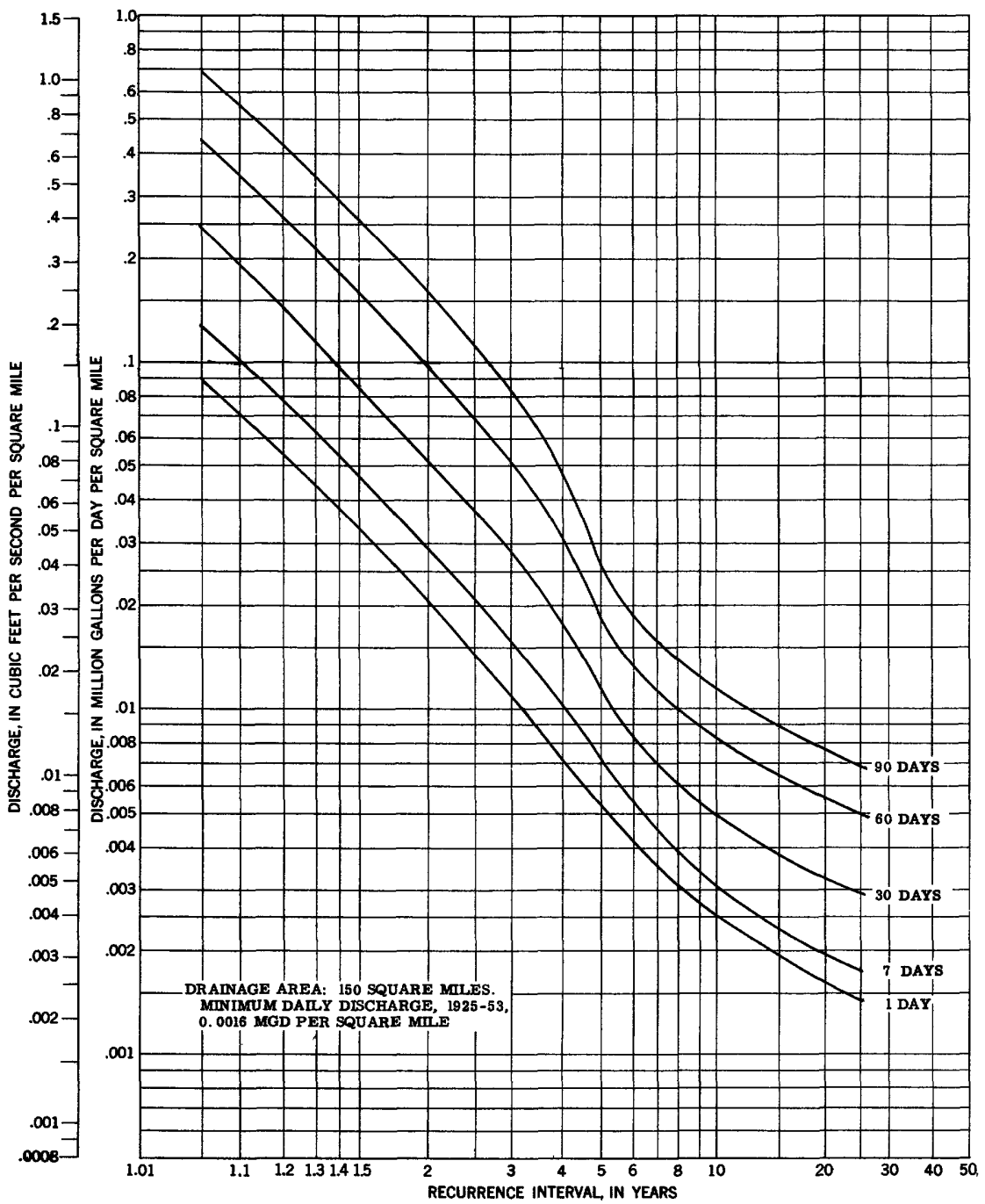

Figure 8. -Magnitude and frequency of annual low flows, Flat River at Bahama, N. C. , based on period $1928-53$. 


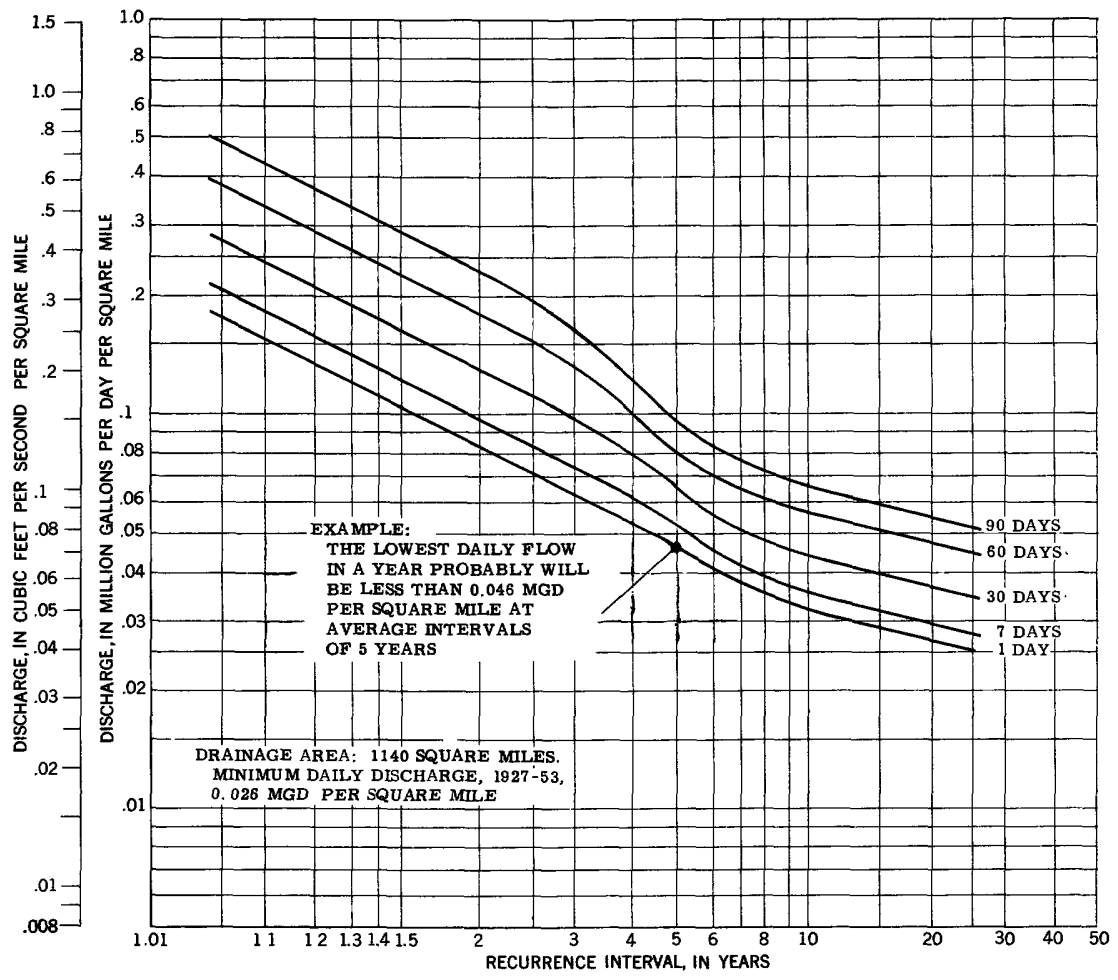

Figure 9.-Magnitude and frequency of annual low flows, Neuse River near Clayton, N. C. , based on period 1928-53.

The curves in figure 10 show that daily flow will be insufficient to satisfy the needs of the hypothetical industrial plant that requires $2.5 \mathrm{mgd}(0.025 \mathrm{mgd}$ per square mile from 100 square miles) at average intervals of 4 years. The average flow for 7 consecutive days will be insufficient at average intervals of 5 years and the average flow for 90 consecutive days will be insufficient at average intervals of 22 years.

\section{MAXIMUM PERIOD OF DEFICIENT DISCHARGE}

Useful analyses of low-flow characteristics may also include curves that indicate the maximum number of consecutive days during which the flow was less than a specified discharge. The maximum period of deficient discharge that may be expected for gaging stations in the Neuse River basin for a 26 -year period in which the flow is similar to that for 1928-53 is shown in figures 12 to 14 and listed in table 6. Again using the example of the hypothetical industrial plant site, assume that it is necessary to 


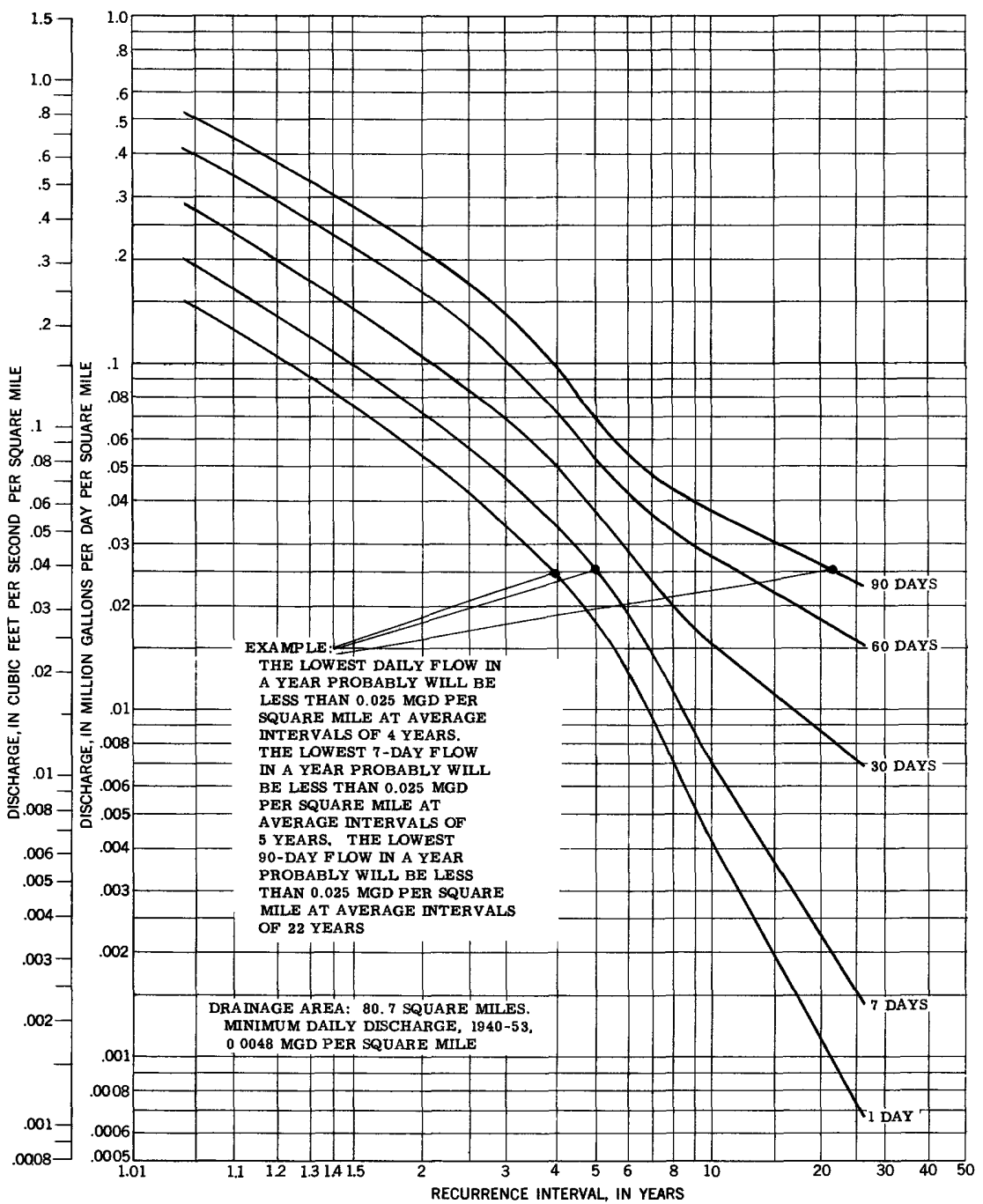

Figure 10.-Magnitude and frequency of annual low flows, Middle Creek near Clayton, N. C., based on period 1928-53. 
know the maximum number of consecutive days, even in unusual years, when the flow will be less than $2.5 \mathrm{mgd}$. Figure 13 shows that the flow of Middle Creek at the plant site may be expected to be less than $0.025 \mathrm{mgd}$ per square mile, or $2.5 \mathrm{mgd}$, for not more than 40 consecutive days.

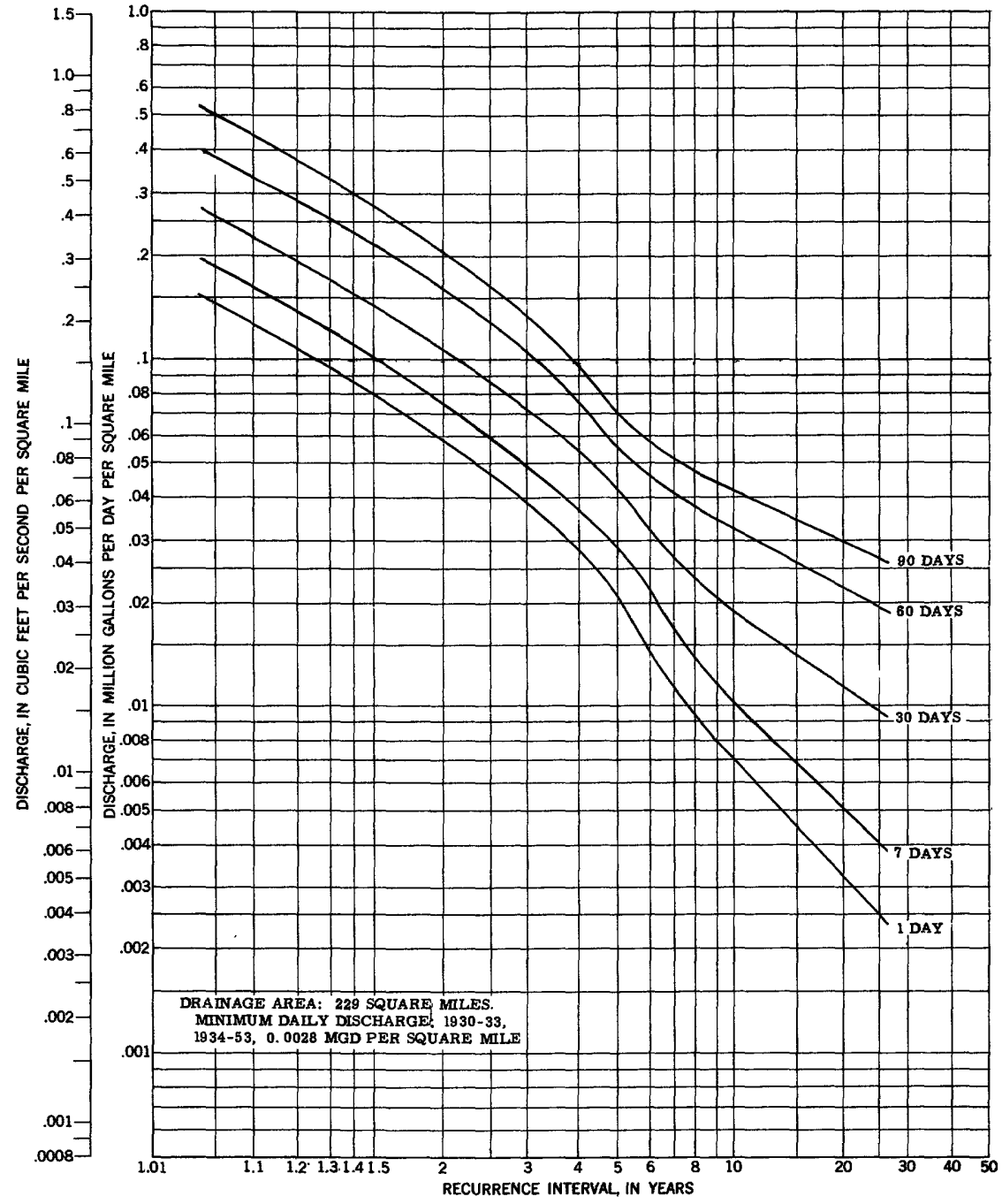

Figure 11. -Magnitude and frequency of annual low flows, Little River near Princeton, N. C. , based on period 1928-53. 


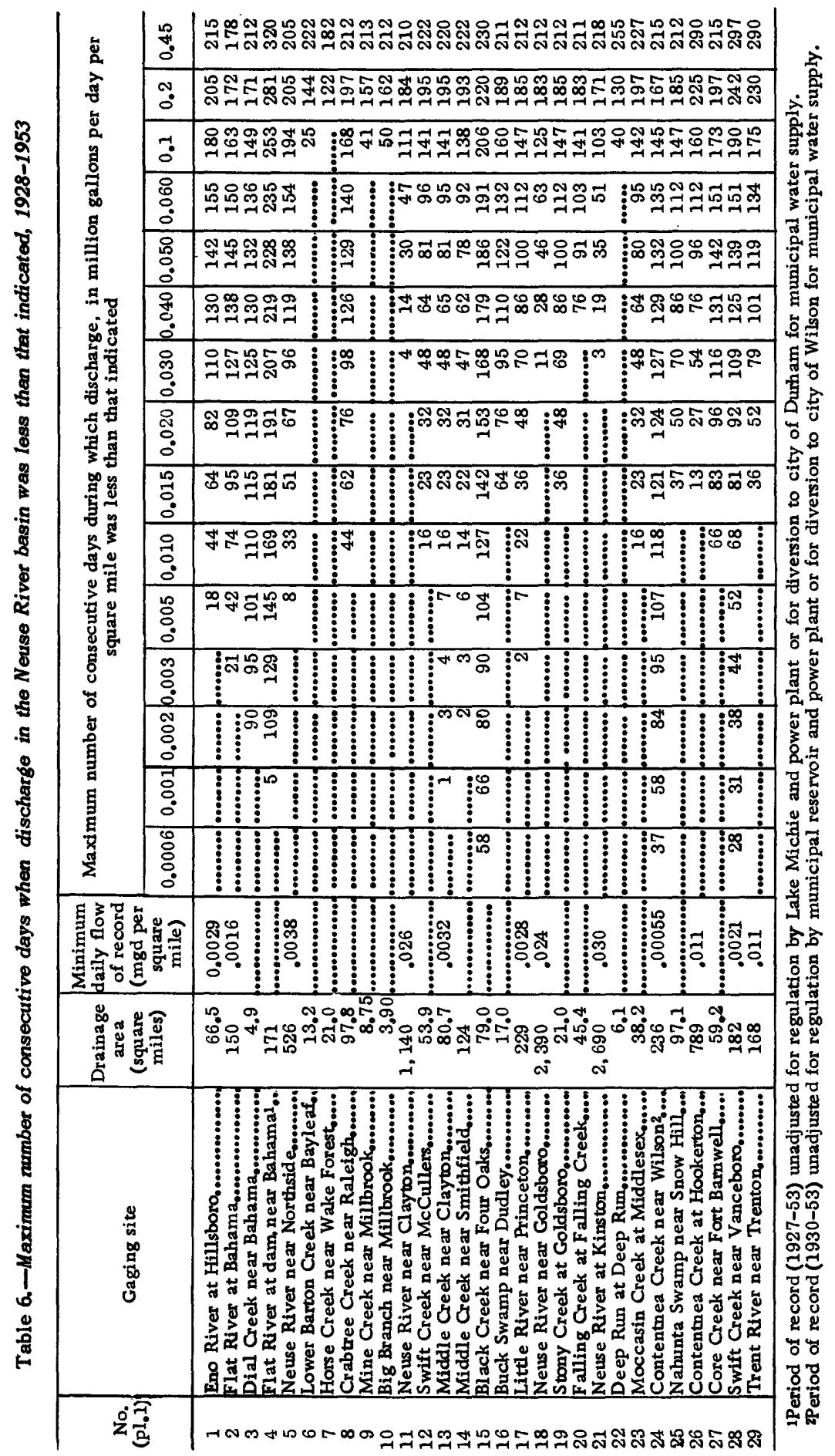




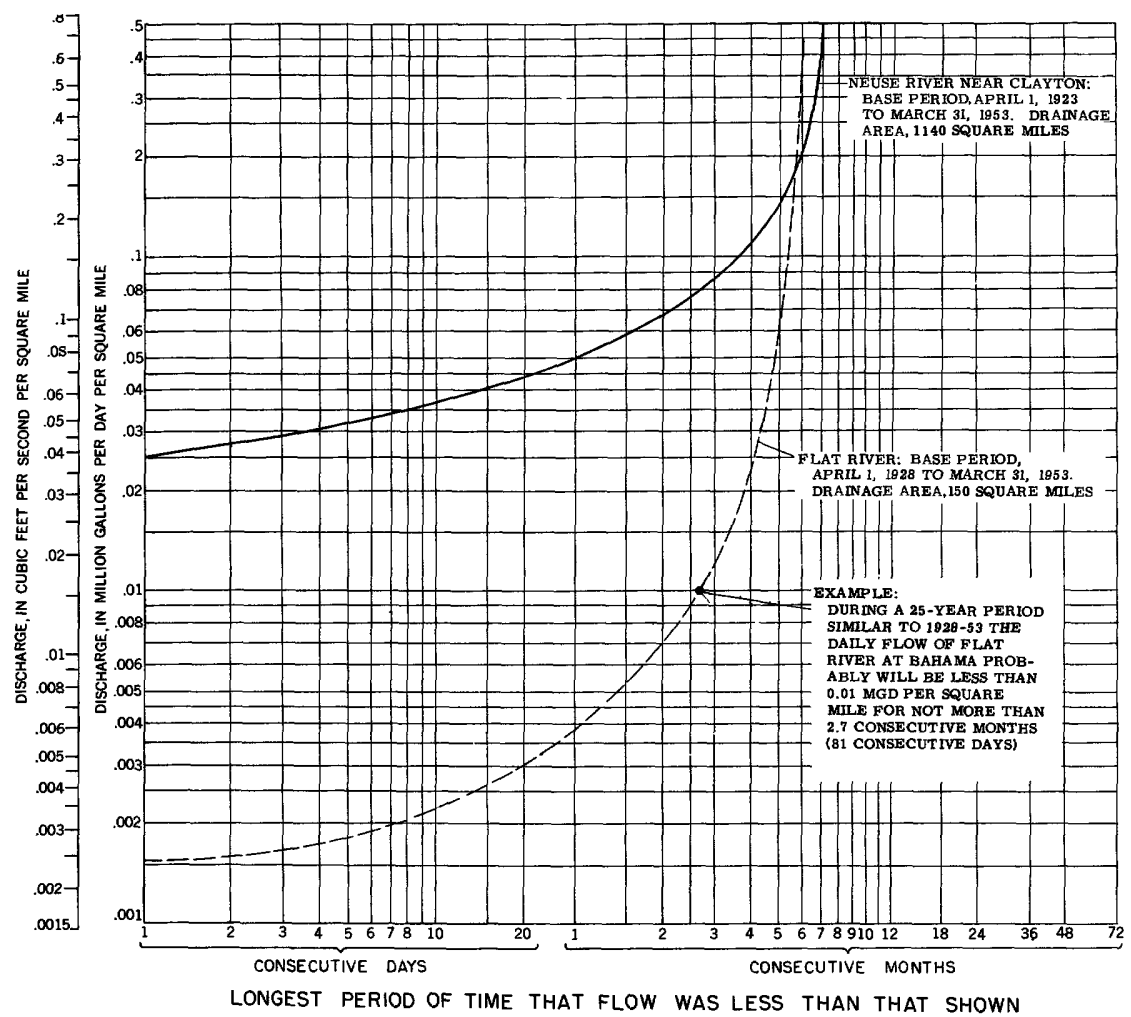

Figure 12. -Maximum period of deficient discharge, Flat River at Bahama, N. C., and Neuse River near Clayton, N. C.

\section{STORAGE REQUIREMENTS}

Frequently during dryperiods streamflow is inadequate to meet the minimum requirements for many uses. Additional flow may be provided during such periods by the use of a storage reservoir. Storage of streamflow is often provided for municipal and industrial water supplies, power generation, supplements to low flows for waste dilution and navigation, flood control, and other uses.

The draft-storage curve is another means of studying the flow characteristics of streams. This curve shows the additional net storage required, disregarding evaporation, leakage, and dead storage, to maintain specific outflow rates. Storage curves for 


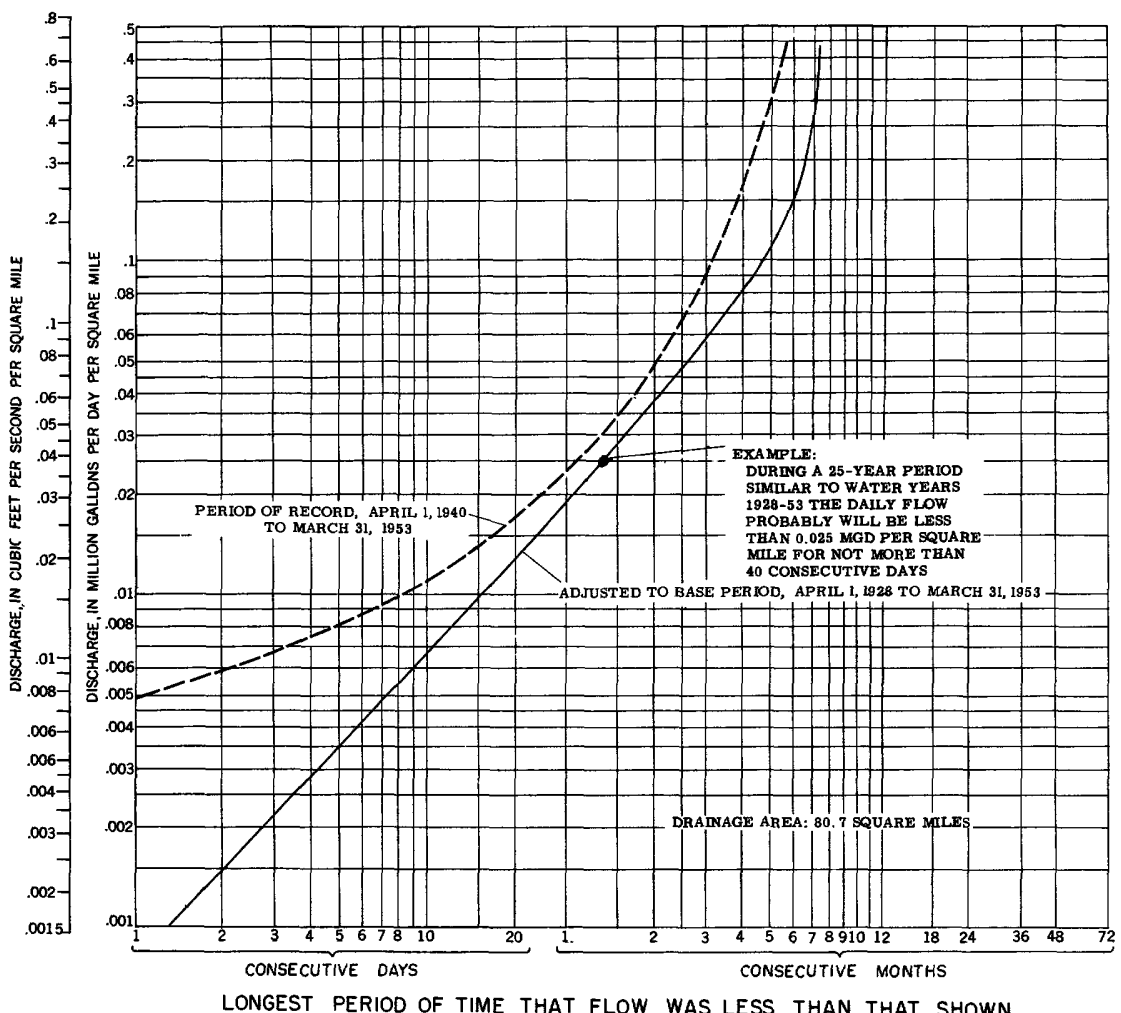

Figure 13. -Maximum period of deficient discharge, Middle Creek near Clayton, N. C.

four representative gaging stations in the Neuse River basin are given in figures 15 to 17 . Net storage for selected outflow rates and the average flow for all sites in the basin are listed in table 7 . In general, the storage curves were computed to 70 percent of average flow.

As an example of the use of the storage curve, assume that the hypothetical industrial plant at a site adjacent to Middle Creek is to be expanded and that the total water requirement is to be 5 mgd. With this new water-supply criterion, the stream will be unable to meet the demand 6 percent of the time, and stoppages or cutbacks in production will be more frequent and of greater proportions than before the expansion. If such a restricted schedule of operation will be uneconomical, it will be necessary to build a storage reservoir to maintain the flow required for continuous operation of the plant. Figure 20 shows that to meet the sustained 


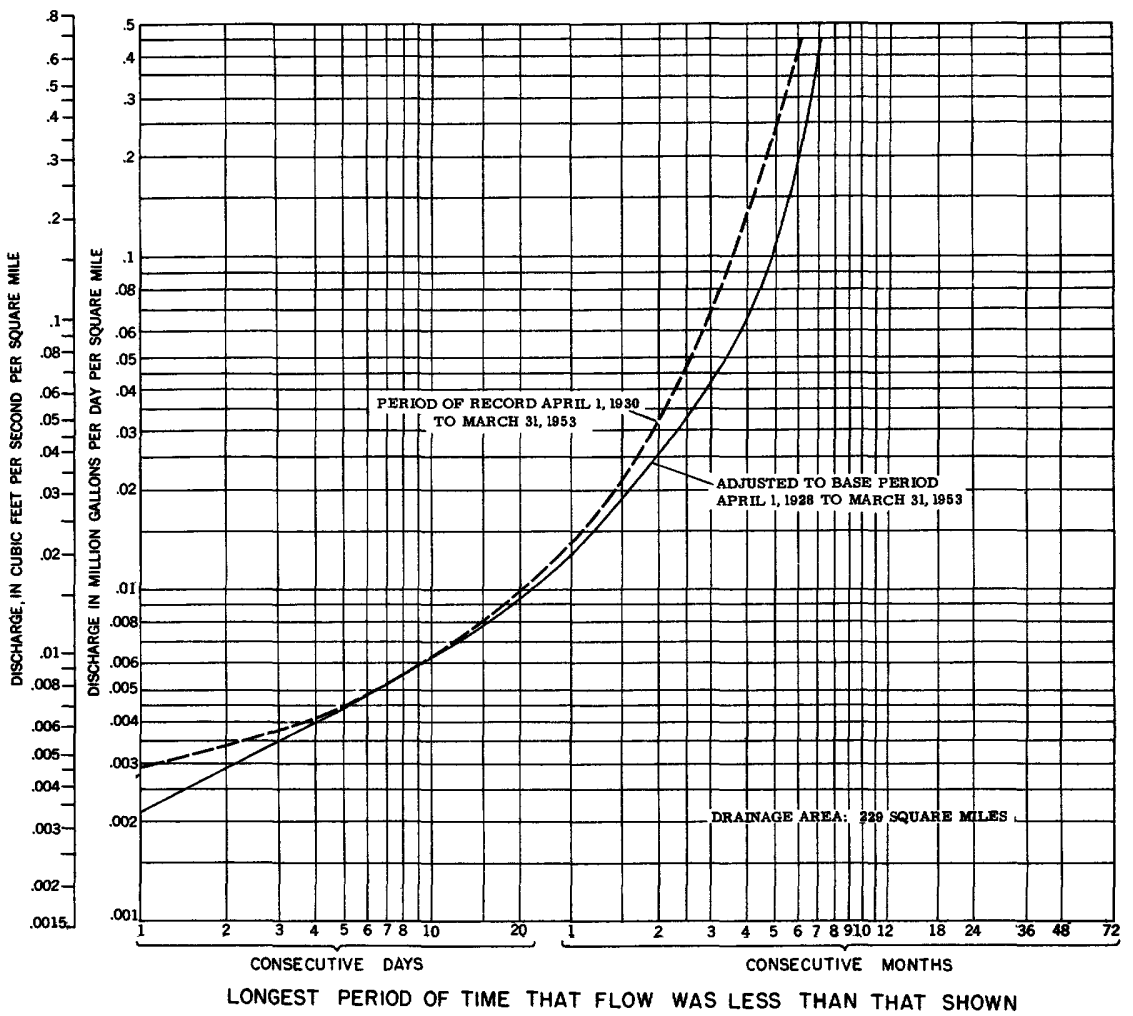

Figure 14. -Maximum period of deficient discharge, Little River near Princeton, N. C. 


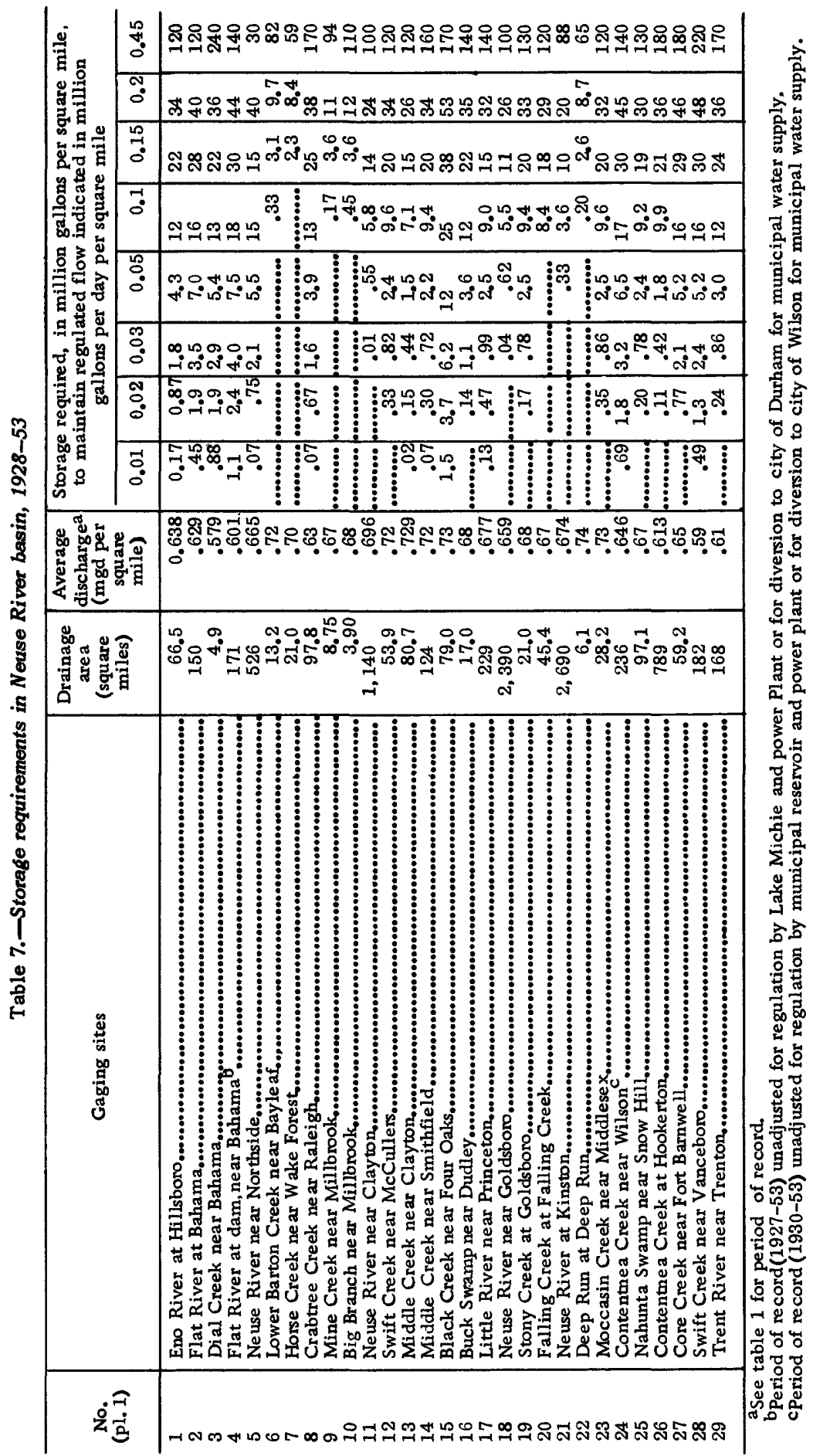




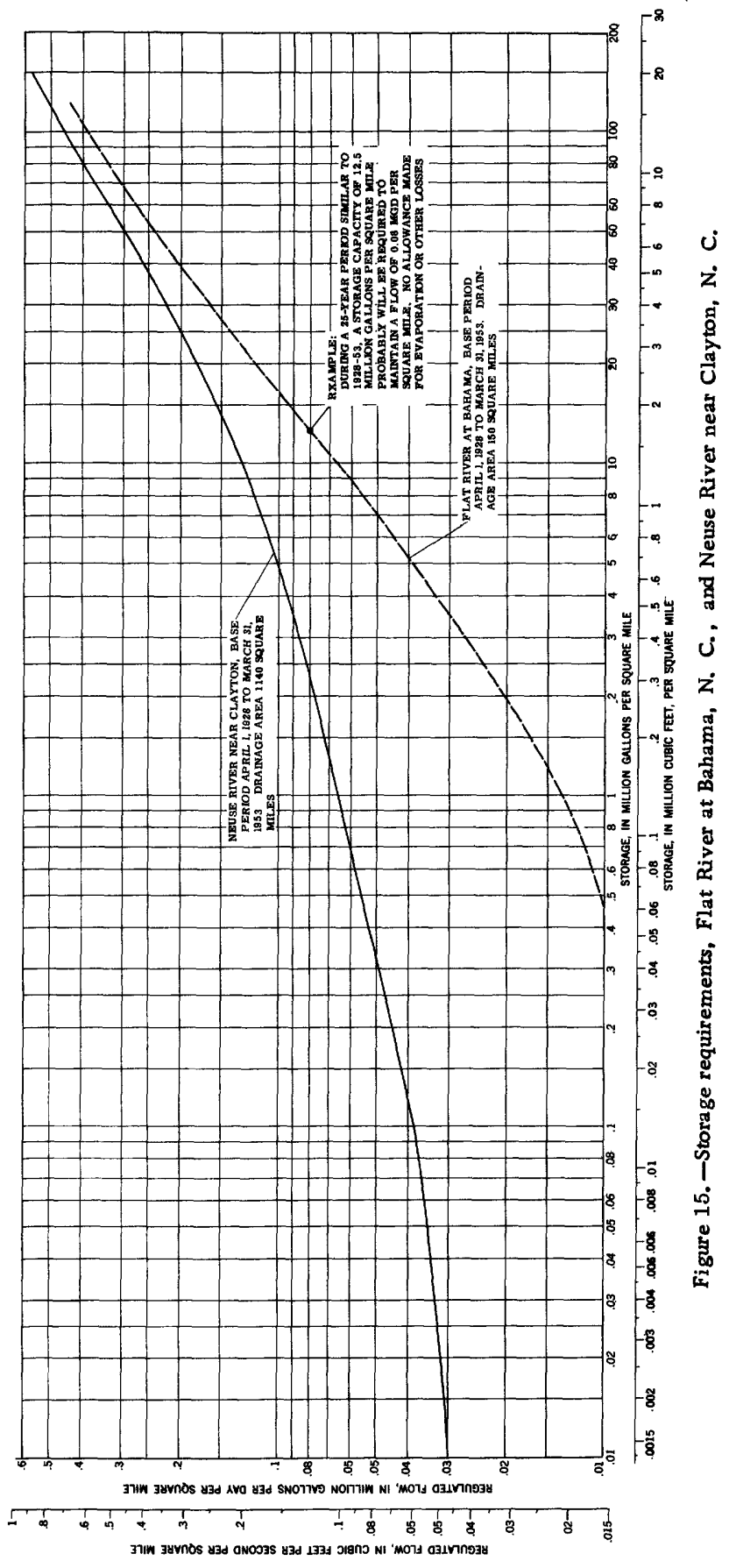




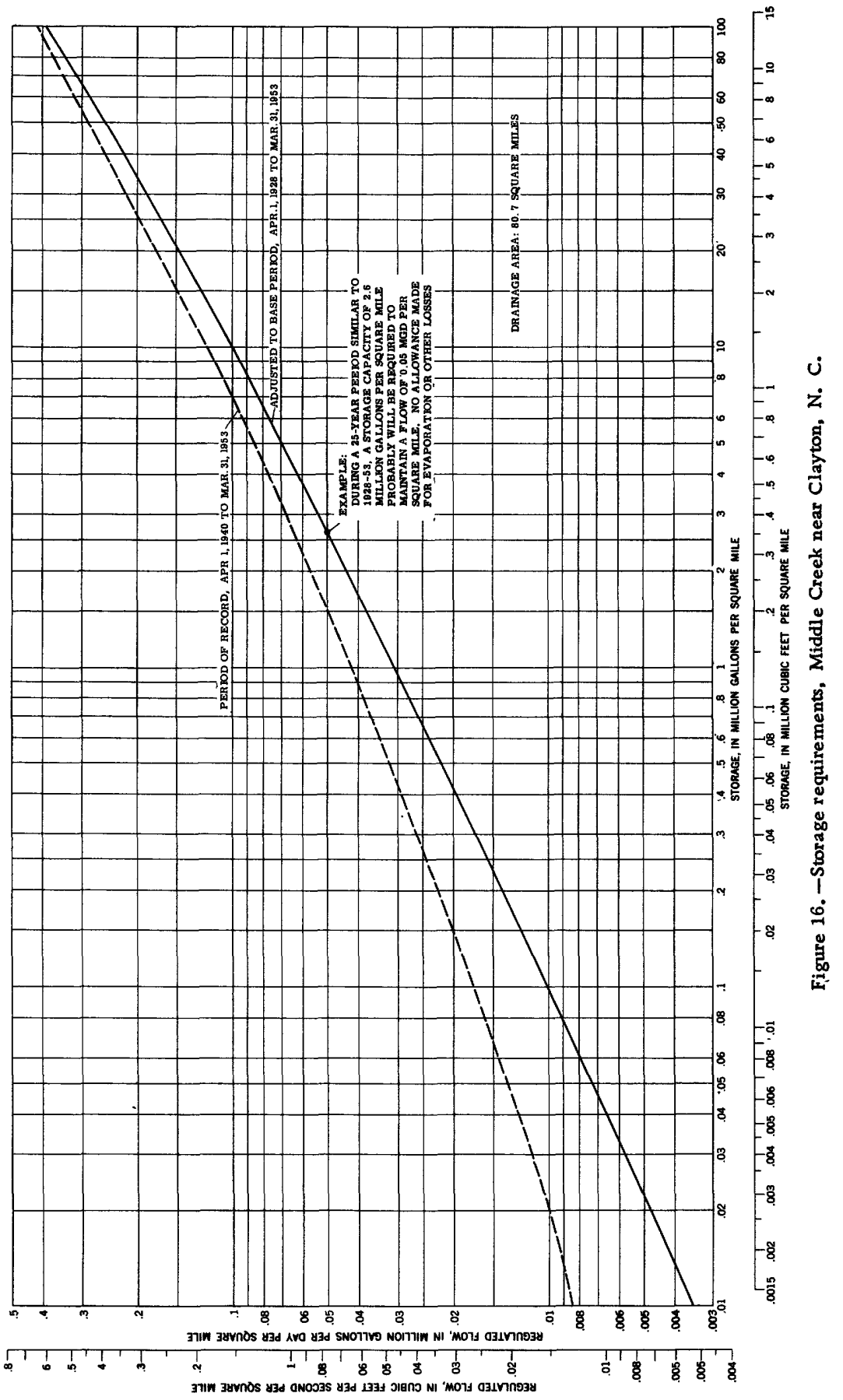




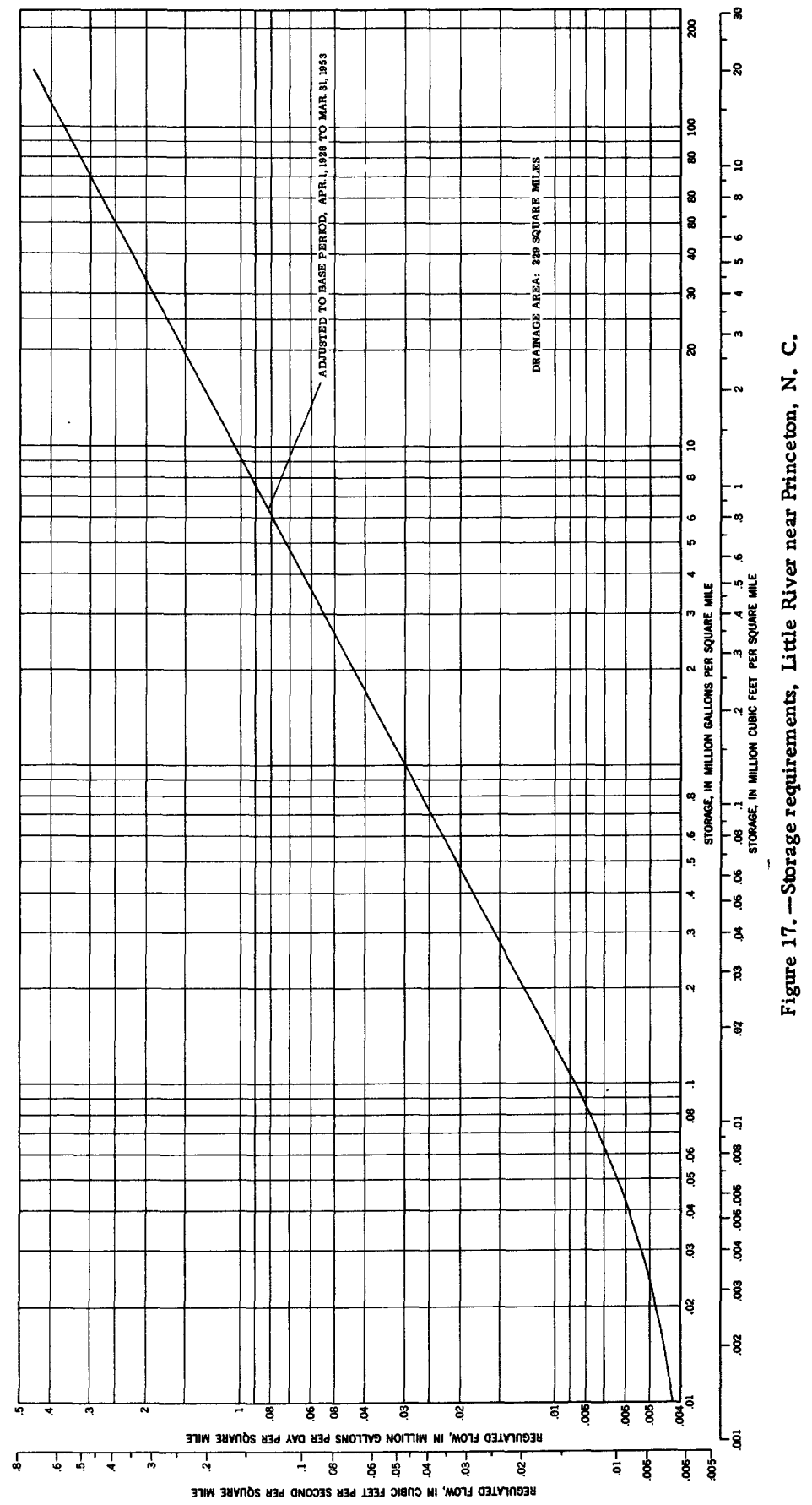


demand of $5 \mathrm{mgd}$ (or $0.05 \mathrm{mgd}$ per square mile) a storage capacity of 2.6 million gallons per square mile of drainage area, or a total of 260 million gallons, will be required. This represents storage for approximately 110 days at critically low flows. To this volume must be added the amount of dead storage below the plant intake and an allowance for evaporation and leakage from the reservoir.

\section{FLOOD FREQUENCIES}

A state-wide study of flood frequency has recently been completed by the Geological Survey (Riggs 1955). Results of this study allow reliable flood-frequency relations to be established for Neuse River basin. These relations are shown for four gaging stations in the basin in figures 18 and 19.

Each frequency curve shows the average interval, in years, between floods that equal or exceed a given elevation. This does not mean that floods occur with any regularity; the recurrence intervals are average values only. It would be possible to have two floods of 50-year recurrence interval in successive years or in the same year.

Although frequency curves give average recurrence intervals only, they have much practical utility. For example, the frequency curve might be used to determine the elevation of a building in the flood plain of a river so that flood waters would reach it, on the average, only once in 50 years. Similarly, the average frequency of flooding of a road fill could be determined from the curve.

However, there are problems in which data on flood frequencies at certain times of the year are needed. To meet this need, summer and winter flood-frequency curves are presented. The summer period extends from May 1 to October 31 , and the winter period is the remaining 6 months of the year. These curves may be used to determine the probability of occurrence of a given flood in the selected season.

For example, suppose that a construction project is proposed for a location near the Neuse River near Clayton at an elevation of 145 feet above mean sea level. By use of figure 18 the recurrence interval of winter floods reaching that height may be determined as 10.8 years. This means that there is about a 1 to 11 chance that the work will be interrupted by flooding if it is done in a winter season. Similarly, from the curve for summer floods that the chances are about 1 in 5 that the work will be interrupted if it is done in a summer season. In the example cited the probability of flooding is greater in summer than in 

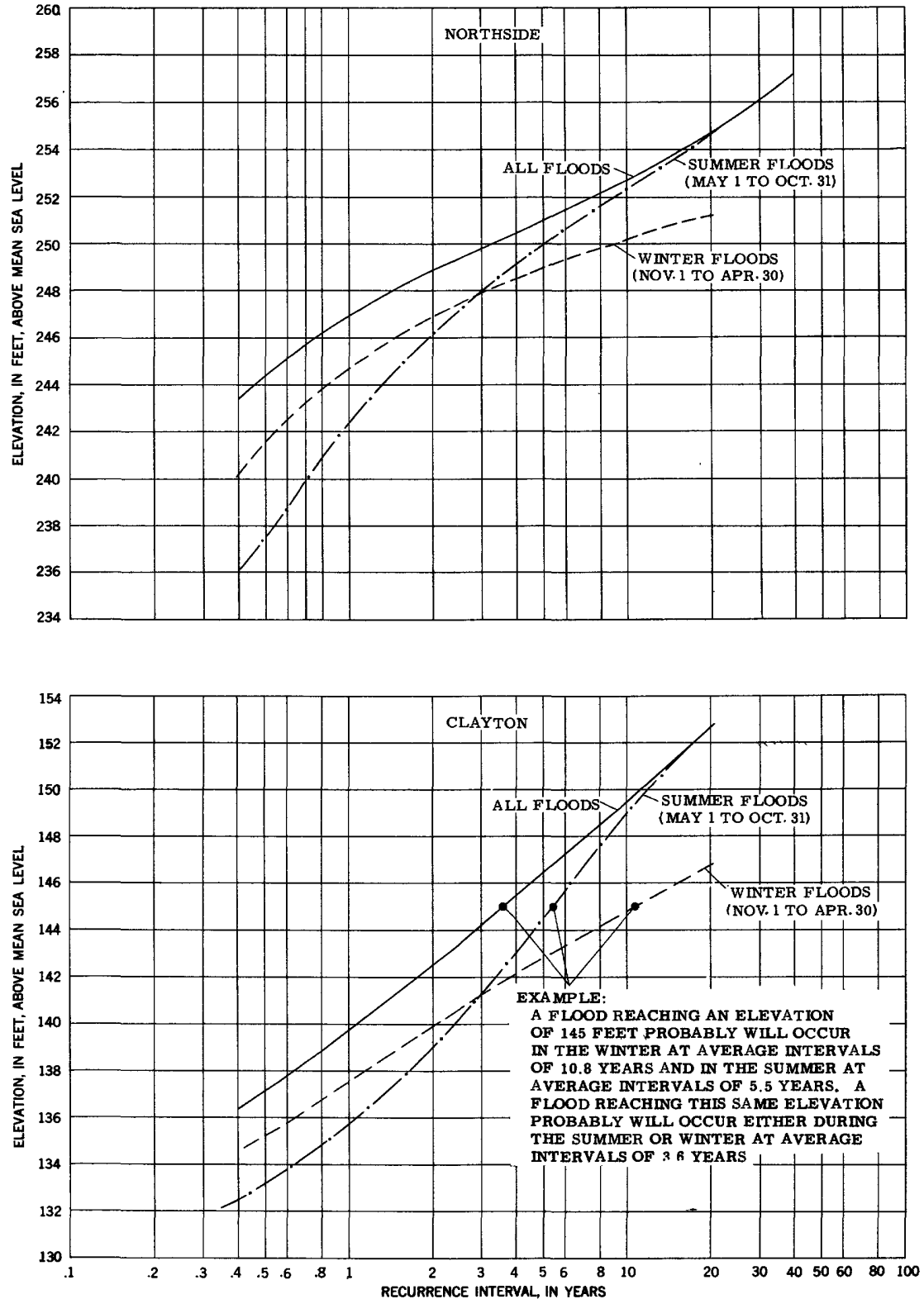

Figure 18. -Flood-stage frequencies, Neuse River near Northside and near Clayton, N. C. 

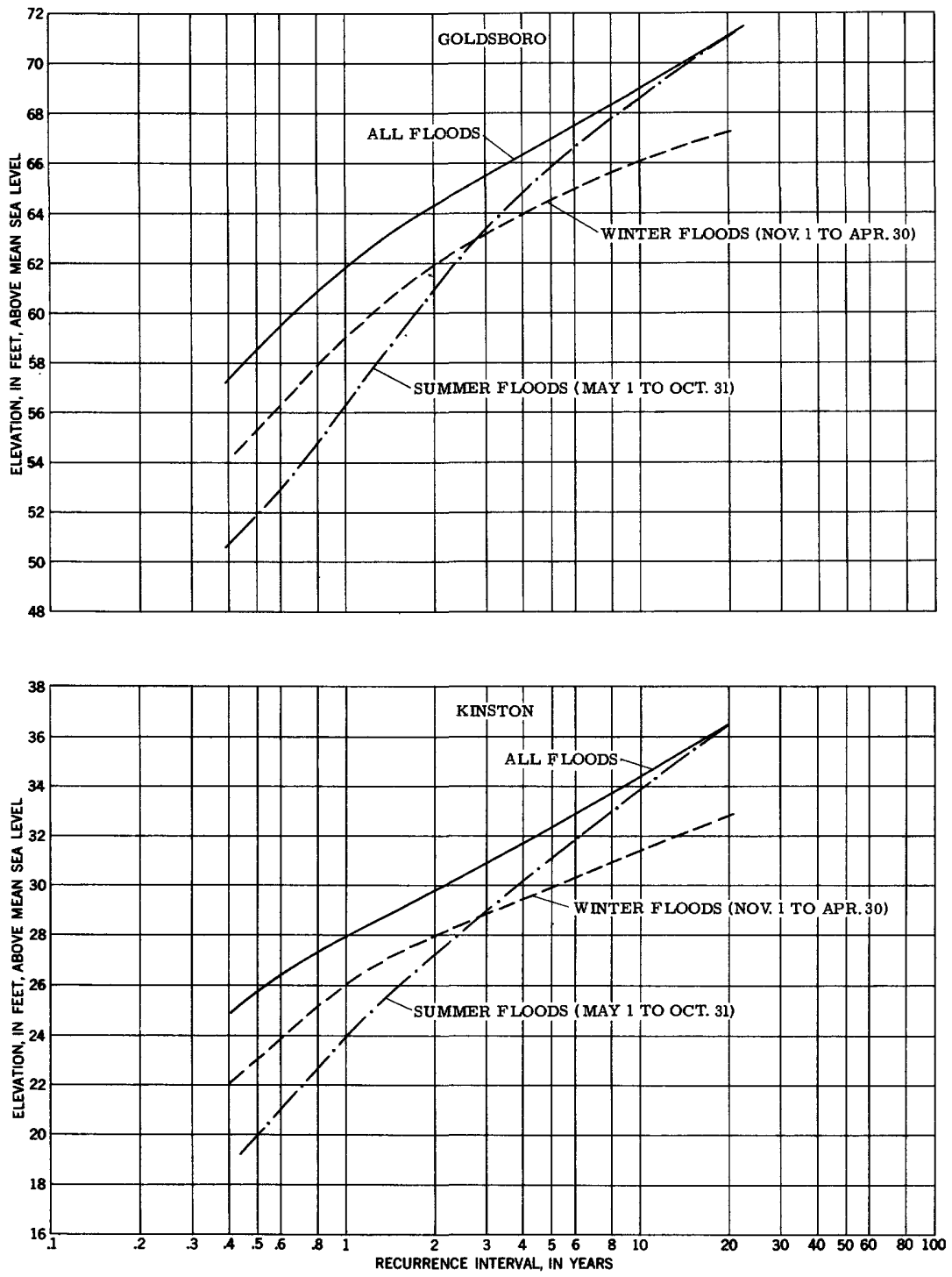

Figure 19. -Flood-stage frequencies, Neuse River near Goldsboro and at Kinston, N. C. 
winter. Conversely, if the elevation at the proposed project site is lower than 141 feet above mean sea level the curves in figure 22 indicate that the probability of flooding in summer is less than in winter but of course much greater than at the higher elevations. The curve for summer floods could also be used to evaluate the risk of farming on a flood plain or of putting the flood plain to other seasonal use.

In general, the curve for frequency of all floods should be used in design of structures that are made to last for several years and the seasonal curves to evaluate the risk of flooding in a single season. The design of dam spillways or other structures whose failure will result in considerable damage or loss of life downstream is usually based on analyses involving maximum known floods rather than a flood of a specified frequency.

\section{QUALITY OF SURFACE WATER}

A program to determine the chemical character of the waters of the Neuse River was begun in 1906. Daily samples for chemical analyses were collected from the Neuse River near Raleigh for a period of 1 year. Additional data were obtained from November 1932 to June 1933. A continuing cooperative program to determine the chemical quality of surface waters in North Carolina was established between the U. S. Geological Survey and the North Carolina Department of Conservation and Development in 1943. Six daily and one monthly sampling stations for chemical quality studies have been in operation on streams in the Neuse River basin for at least 1 year each since 1943 (table 2). In addition to the daily and monthly sampling stations, samples for chemical analyses have been collected intermittently at all complete- and partialrecord gaging stations within the basin. The mineral constituents and physical properties that have a practical bearing on most uses of surface water are summarized for each daily sampling location in table 8. Figure 20 shows the average chemical character of the surface water at each of the daily sampling stations in the basin during the period 1943-54. The relation of hardness to dissolved solids of surface waters in the Neuse River basin is shown in figure 21 .

The relation between streamflow and the chemical and physical characteristics of Neuse River water near Clayton during the 1944 water year is shown in figure 22. The highest color occurred during November. The hardness varied only slightly with streamflow; whereas, the dissolved solids fluctuated with the flow, being greatest during October through most of December and during the latter part of summer when the streamflow was the lowest. The 


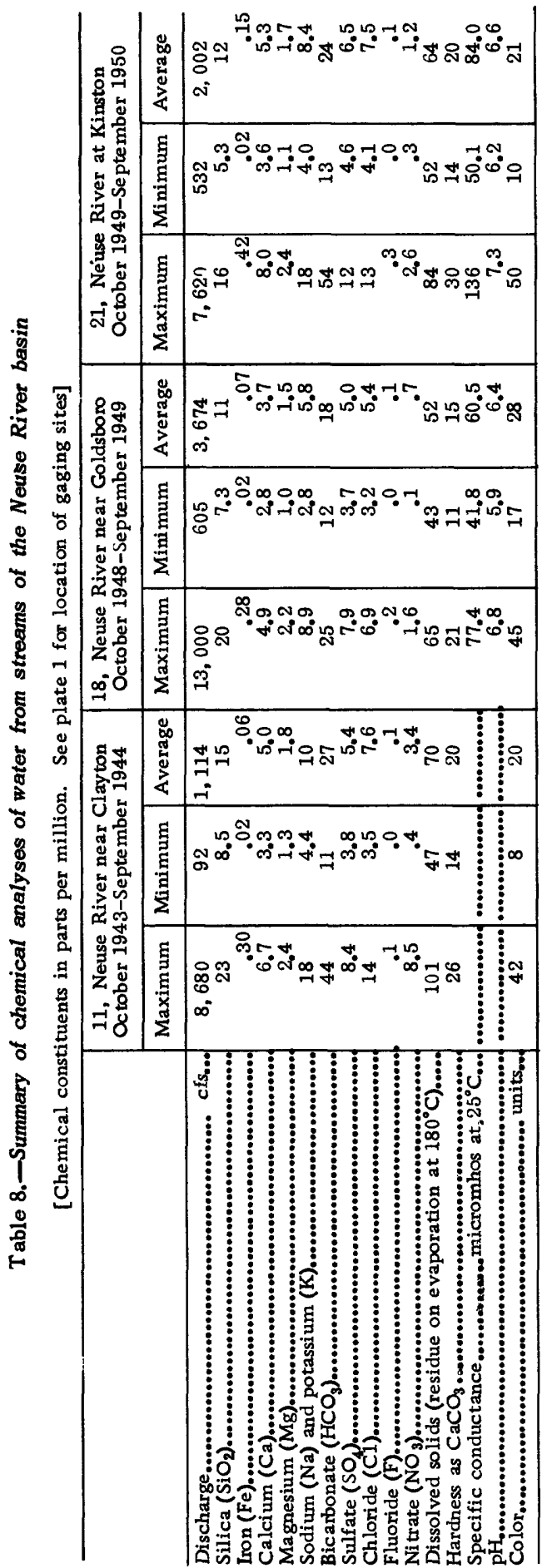




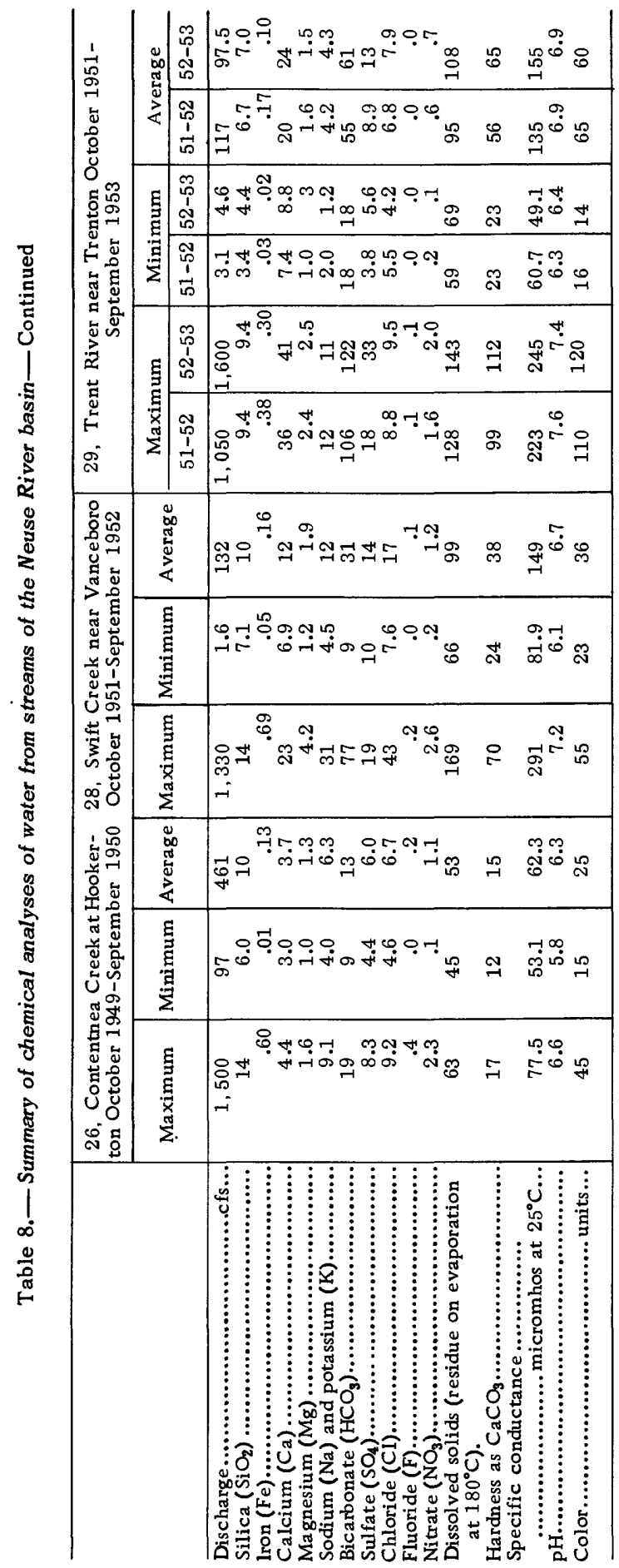


PERCENT DISSOLVED SOLIDS (SUM)

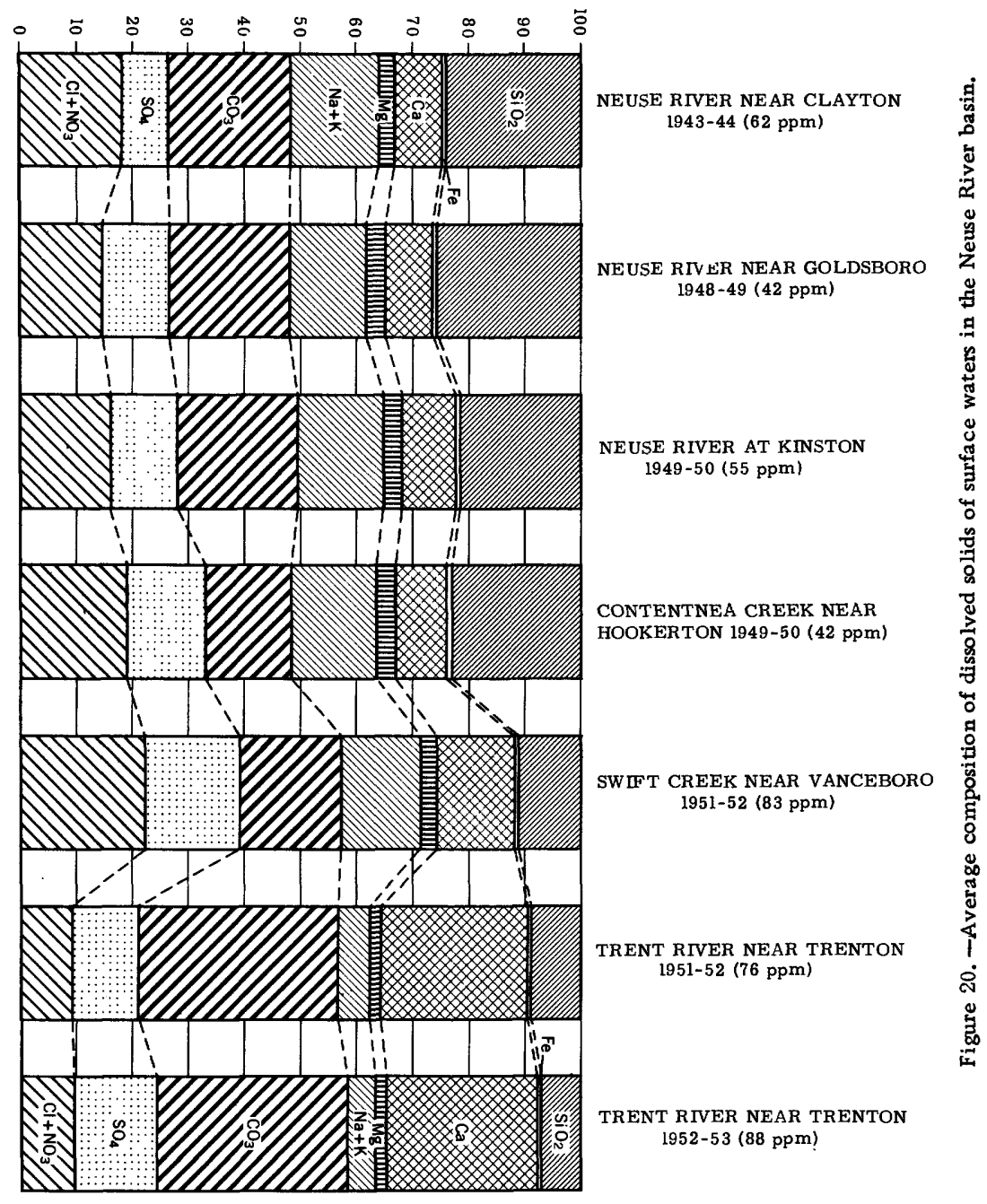




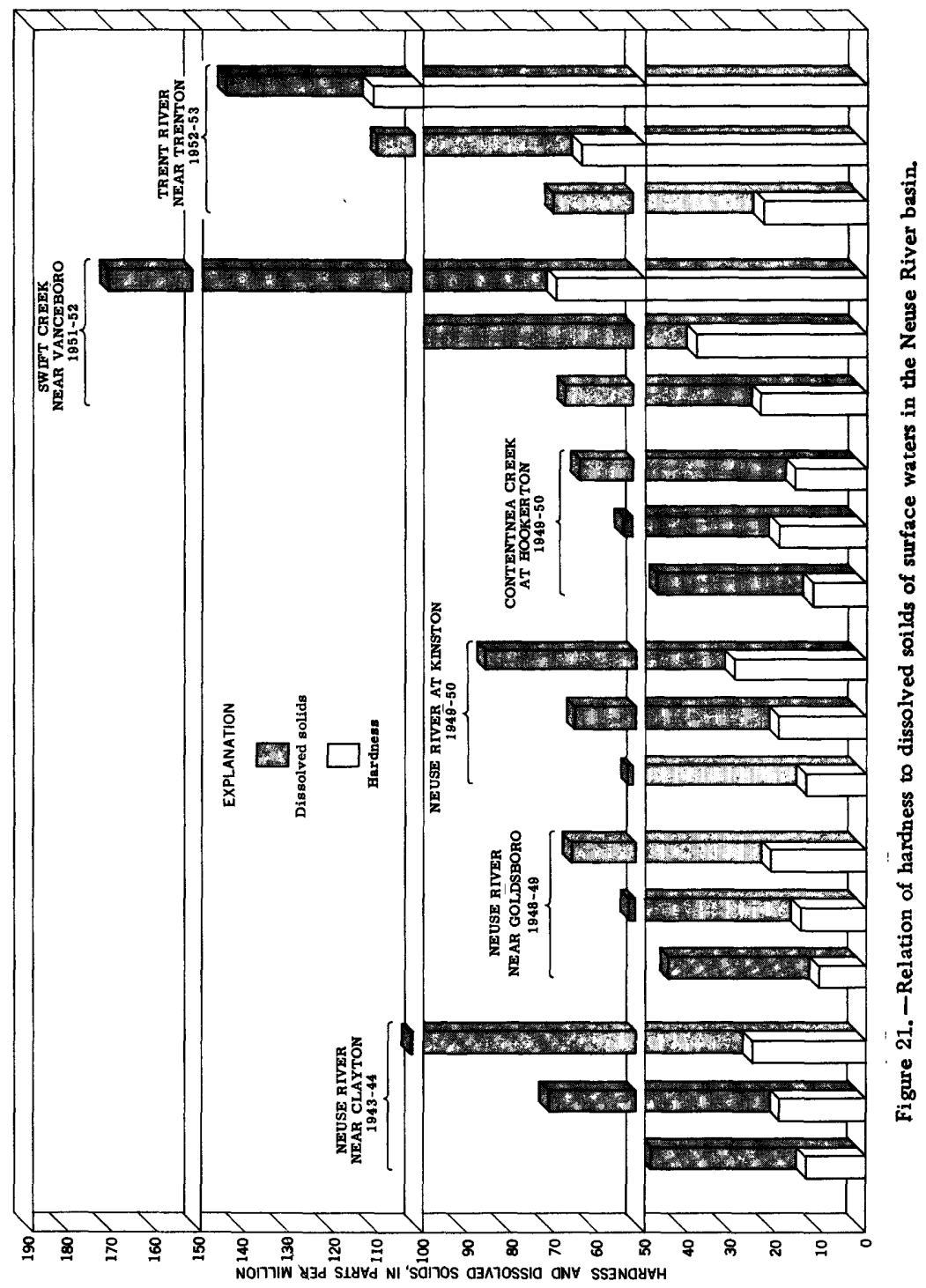



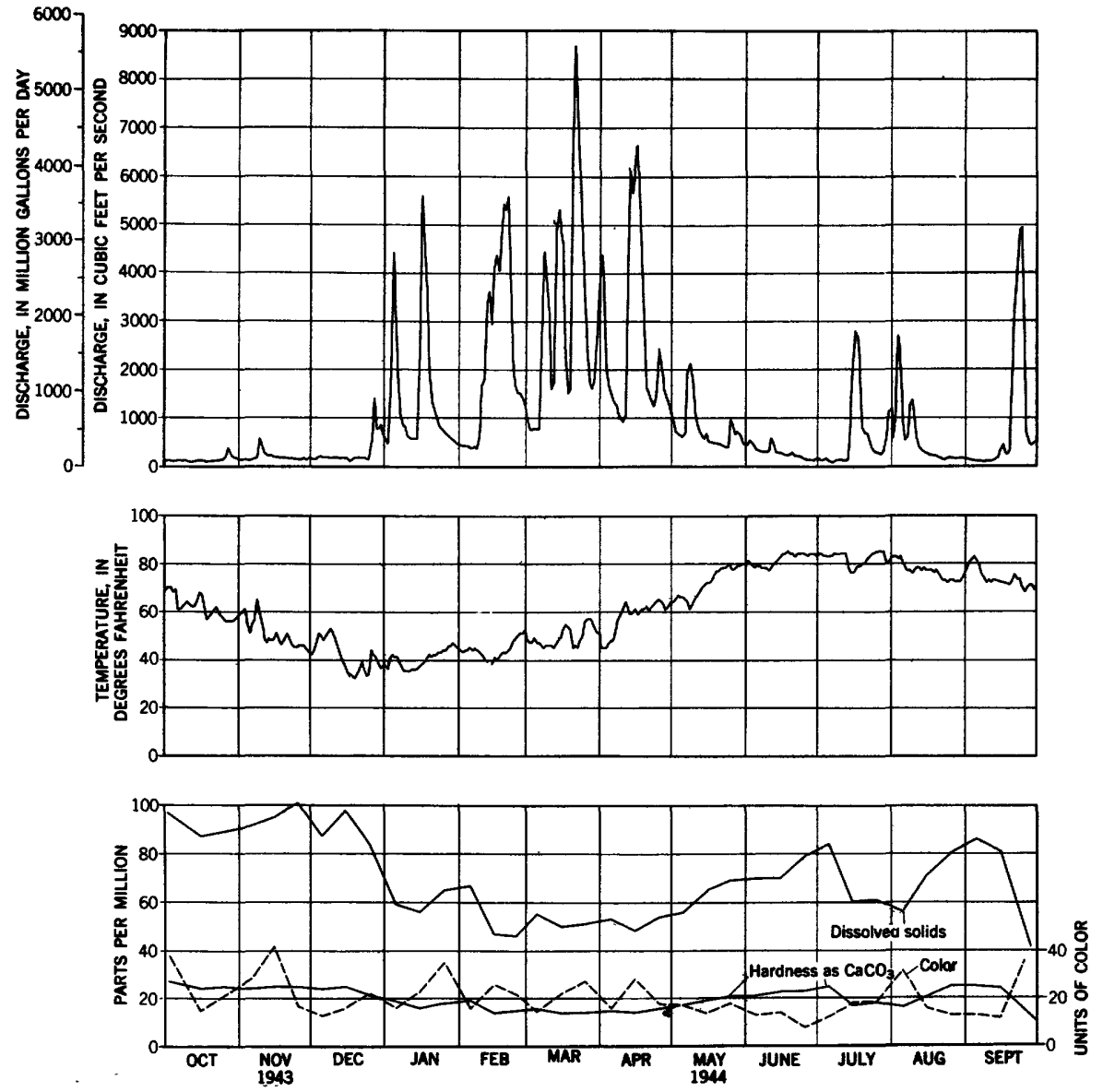

Figure 22, - Relation between streamflow and selected chemical and physical characteristics of Neuse River near Clayton, N. C., 1943-44.

highest temperature occurred during June, July, and a few days in August and September. Smithfield, about 10 miles below the Clayton station, uses Neuse River for its public water supply. Inasmuch as there is no appreciable amount of inflow between Clayton and Smithfield, the chemical and physical characteristics of the Neuse River at Smithfield are similar to those near Clayton.

Little River is the source of the public water supply for Goldsboro. Except for excessive quantities of iron and color, the chemical quality of the water from Little River is excellent. The dissolved solids ranged from 44 to $56 \mathrm{ppm}$ and hardness from 9 to $22 \mathrm{ppm}$.

The water from Contentnea Creek generally is suitable for an industrial or public water supply on the basis of the mineral content. The uniformity of the dissolved solids and low hardness 
makes it very desirable for most uses (see p. ). Color ranged from 15 to 45 units during the 1950 water year. Contentnea Creek drains several swamp areas that contribute colored waters to the main stream.

Several swamp streams flowing into Swift Creek contribute to the color of the water $(23-55)$. There were objectionable amounts of iron in the water during the period of record, October 1951 to September 1952. Contamination from salt water is likely in the lower part of the stream.

The hardness of waters from Trent River near Trenton is greater than from the other streams in the basin. The dissolved solids ranged from 59 to $128 \mathrm{ppm}$. The waters are colored (23 to 110 units) because of inflow from many swamp streams.

Salt-water encroachment in the lower region of the Neuse River basin has adversely affected the chemical quality of the surface waters in the area. The chemical quality of surface waters varies with the tide and the extent of salt-water encroachment. At the mouth of the Neuse River the salinity is very high, at times as much as 10,000 ppm of dissolved solids. The salinity decreases upstream until the limit of salt-water encroachment is reached. Adequate data are not available to indicate the upstream limit of encroachment.

\section{GROUND WATER}

OCCURRENCE OF GROUND WATER

In the hydrologic cycle some of the precipitation that falls on the earth's surface percolates downward until it saturates the rock with water. Water in the zone of saturation is known as ground water; it comes to the surface again through springs and seeps, is withdrawn from wells, or is evaporated or transpired by vegetation.

Rocks are composed of mineral grains of many shapes and sizes and contain openings that may hold water. In sedimentary rocks, such as sand and clay, there usually are great numbers of interstices; but in igneous and metamorphic rocks, such as granite and slate, the spaces that are large enough to yield water are generally due to fracturing or solution of the rock. The porosity of a rock is the ratio of the volume of the pore spaces to the total volume of the rock. 
If the interstices are large enough and are interconnected, water will move readily through them and the rock is said to be permeable. If the spaces are too small or are poorly connected, the rock is relatively impermeable and water will move through it very slowly. If a rock has sufficient permeability to allow usable amounts of water to be withdrawn from it, it is called an aquifer.

In rocks that contain interconnected openings extending to the land surface, the water that saturates the rock below a certain level forms a body whose upper surface is the water table. In valleys the water table generally is at or near the ground surface, whereas on hills the water table may be 60 feet or more below the surface. The water table fluctuates throughout the year as water is withdrawn by wells, by evapotranspiration, and by seepage to streams or as water is addedafter a storm. Where the water level in wells is free to fall and rise in response to these influences, the aquifer is said to be under water-table conditions.

In the Coastal Plain formations of the Neuse River basin, there are many alternating layers of permeable sand and impermeable clay sloping southeastward beneath the surface. (See fig. 23.) Water moves through the sand easilybut its movement through the clay is retarded. Water entering the sand at higher elevations exerts a considerable pressure on the water already confined in the sand, and this pressure forces water upward against the clay beds overlying the sand beds. Water under pressure of this kind is said to be under artesian conditions, and a well in which the water level rises above the base of the overlying confining bed is known as an artesian well. At many places in the basin, there is sufficient artesian pressure to cause wells to flow at the surface.

As 'xater is removed from an aquifer it must be replaced or the water stored in the aquifer ultimately will be exhausted. Precipitation is the source of this recharge water, replenishing the underground water supply throughout the basin, either by direct

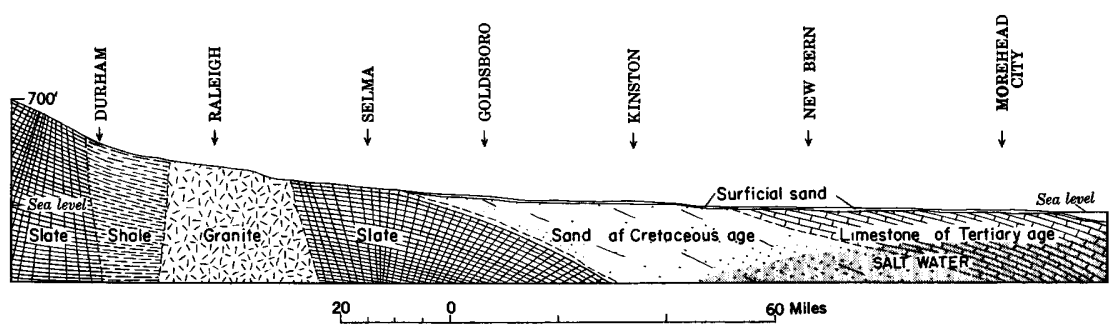

Figure 23. - Generalized cross section of the Neuse River basin showing the major rock units. 
downward seepage under water-table conditions or by percolation into the artesian aquifers in areas where they crop out at the surface or can otherwise receive water. If yields are to be sustained indefinitely, withdrawal of water must not exceed average recharge; in addition, withdrawal must not be so great as to induce the encroachment of water of poor quality.

Generally, water first entering the ground tends to move toward nearby streams and discharge into them. If water levels are lowered sufficiently in wells that penetrate permeable strata near these streams, a reverse flow may occur and the ground-water reservoir will receive recharge from the streams. Recharge of this type, known as induced infiltration, is important at many places in the United States but does not now take place on any significant scale in the Neuse River basin.

Pumping lowers the water pressure at a well and establishes a hydraulic gradient that allows water to flow toward the well. As pumping continues to lower the water level in the well, the influence of the gradient extends farther away and water may be intercepted that ordinarily would discharge elsewhere. If the discharge thus salvaged is sufficient, water levels will eventually stabilize, and large yields may be sustained. Conditions of this type seem to exist near Kinston as a result of heavy pumping at a large textile plant there.

In the Neuse River basin, most ground-water supplies are obtained from wells. Most springs have poor yields and are inaccessible, so that it is difficult and expensive to develop water supplies from them. A properly located and properly constructed well, however, is a dependable and economical source of water. Wells are the oommon source of water for rural domestic use, and many towns also have wells for their supplies.

\section{GEOLOGY}

The movement and availability of ground water depend upon a number of geologic factors, such as the type of rock, the way the the grains are held together, and the way the rocks are fractured. In general, the rocks of the Piedmont are dense slate, granite, and similar rocks, but there are also some compact shale and sandstone. The rocks are exposed in about half the basin and slope beneath the rocks of the Coastal Plain to the southeast. The rocks of the Coastal Plain are composed chiefly of beds containing variable amounts of sand and clay, some being relatively pure in sand and others relatively pure in clay; limestone, some of which is consolidated into a hard rock, is interlayered at many places with 
the sand and clay. These strata slope eastward at a slightly greater rate than does the land surface and so are buried progressively deeper toward the coast. These formations increase in thickness from a featheredge near the fall line to a probable maximum of 4,000 feet along the coast. The general relations among these Piedmont and Coastal Plain rocks are shown in figure 23.

\section{ROCKS OF THE PIEDMONT}

Slate rocks. -A series of interbedded tuff, breccia, lava flows, shale, slate, and schist, all called slate rocks for convenience, underlie the northwesternmost part of the basin ( $A$ and $D$ in pl.2). These rocks, which are predominantly gray to greenish blue, include also quartz veins and diabase dikes. Generally, these rocks are tipped on end and trend northeastward. They are predominantly acidic in composition, but the iron minerals have stained the weathered soil zone brown or dark red. Jointing and shearing are common features within several hundred feet of the surface. The total thickness of the slate rocks is unknown but is many thousands of feet. These rocks, probably of early Paleozoic age, are found chiefly in the northwestern end of the Neuse River basin in the vicinity of Hillsboro ( $A$ in $\mathrm{pl} .2)$ and in the fall line area around Middlesex and Smithfield ( $D$ in pl. 2).

Granite. - The granite ( $C$. in pl. 2), especially well exposed in the vicinity of Wendell, is gray or pink medium- to coarse-grained massive to well-fractured rock. An extensive body of fine-grained generally massive gneiss, composed chiefly of quartz, mica, and feldspar, is found in the vicinity of Raleigh and Wake Forest and is included with the granites in this report. Banding trends northwestward in the gneiss. Because of a thick soil zone, the areal relations between the metamorphic rocks and the granite are obscure, but all extend downward to an unknown but great depth.

Shale rocks. - The consolidated shale, claystone, sandstone, conglomerate, and arkose beds of the Upper Triassic Newark group ( $B$ in pl. 2), all called shale rocks for convenience, occupy a northeastward-trending fault trough, or graben to a depth of 8,000 to 10,000 feet. Beneath a thin reddish-brown soil zone the rocks, chiefly shale, are compact and well cemented, but many faults and diabase dikes cut the gently to moderately sloping strata. These rocks, exposed north and east of Durham, contain some thin beds of coal, which are not mined. 
Tuscaloosa formation. - The basal formation of the Coastal Plain exposed near the fall line is the Tuscaloosa formation of Late Cretaceous age. It consists of gray, yellow, red, and tan clay and sandy clay and some gravel. The beds increase in thickness from a featheredge in the middle part of the fall line area to about 100 feet at Goldsboro and to about 560 feet at Morehead City. They dip southeastward at about 15 feet per mile in much of the basin, but this slope increases near the coast. Somewhere down the dip, similar sediments of Early Cretaceous age may intervene between the Tuscaloosa formation and bedrock, but these, if present, would be hydrologically similar to the Tuscaloosa.

3lack Creek formation. -Dark-gray to black laminated lignitic clay alternates with fine-grained gray sand beds in the Upper Cretaceous strata that overlie the Tuscaloosa formation. The Snow Hill marl member, at the top of the Black Creek formation, is a fossiliferous glauconitic sandy marl. The formation dips southeastward, beginning at Goldsboro, and increases in thickness to about 600 feet at the coast.

Peedee formation. - The Peedee formation of Late Cretaceous age consists of interbedded clay, sand, marl, and limestone that dip southeastward at 10 to 25 feet per mile, increasing in thickness from a thin edge near LaGrange to a maximum of 600 feet. The formation is fossiliferous and contains much glauconite.

Castle Hayne limestone. - The Castle Hayne limestone is light- to darkgray poorly to well consolidated limestone and sandy limestone or marl containing abundant shells. The formation has a slight southeastward dip and increases in thickness from a featheredge near Kinston to more than 250 feet along the coast.

Yorktown formation. - The Yorktown formation is an extensive fossiliferous formation, of Late Miocene age, covering much of the northern half of the basin, increasing in thickness from a few feet near Wilson to more than 150 feet near Cherry Point. In lithology, the formation varies from a sticky blue clay to a loose shell marl.

Surficial sands .- Surficial sands mantle much of the Coastal Plain. They consist of series of thin beds of sand and clayey sand, which in part are, derived from underlying formations but which include some sand, clay, and shell beds of Pleistocene age. The surficial beds probably do not exceed 30 feet in thickness except along the coast, where well-developed sand dunes are found. 
Ground-water conditions are not uniform throughout the Neuse River basin. Several ground-water provinces have been differentiated because of significant differences in character and structure of the rocks, yield of wells, and quality of water. The aquifers in each province consist of one or more bodies of rock having similar hydrologic properties. Although these aquifers are distinctive in most places, it is evident that they lose some of their identity where they adjoin other aquifers. The quantity and quality of water that can be obtained from each of the water-bearing units varies with the type of well and its location and depth. The areal extent of each of the ground-water provinces is delineated in plate 2 .

The chemical quality of the ground water in the Neuse River basin is summarized in table 9 . Selected analyses of water from each ground-water province are presented graphically in figure 24. The occurrence of iron and hardness in ground water in the Neuse River basin is given in figure 25 .

\section{CRYSTALLINE-ROCK PROVINCE}

The crystalline-rock ground-water province consists of the areas underlain by rocks described as the slate rocks, granite, and shale rocks. Together, these rocks form the poorest aquifer in the Neuse River basin.

In general, the slate rocks and granite ( $A$ and $C$ in pl.2) are massive crystalline rocks whose grains are intergrown or held together by molecular attraction. Pore space is negligible and usable water is found only along bedding planes, along planes of cleavage and schistosity, and in zones where fracturing and solution have occurred.

Many of the openings in the slate rocks and granite are the result of weathering processes that operate close to the earth's surface. A well will generally find fewer openings as it is deepened, so that it is usually not worth while to drill wells to great depths. Coarse-textured rocks generally are relatively good producers because weathering or fracturing will tend to open larger spaces in them than in fine-textured rocks.

Much water is stored in the weathered, or decayed, rock that lies immediately below the surface. This water will recharge underlying fractures as wells are pumped, and good yields may result if the weathered zone is thick and permeable. 


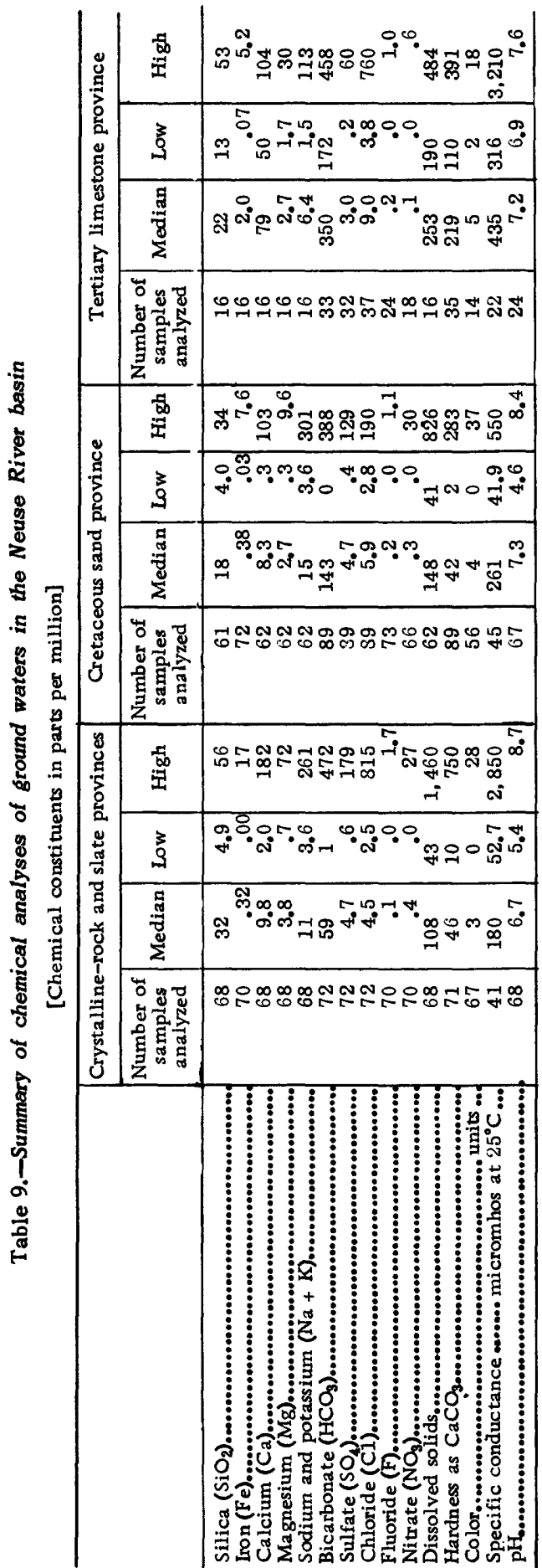




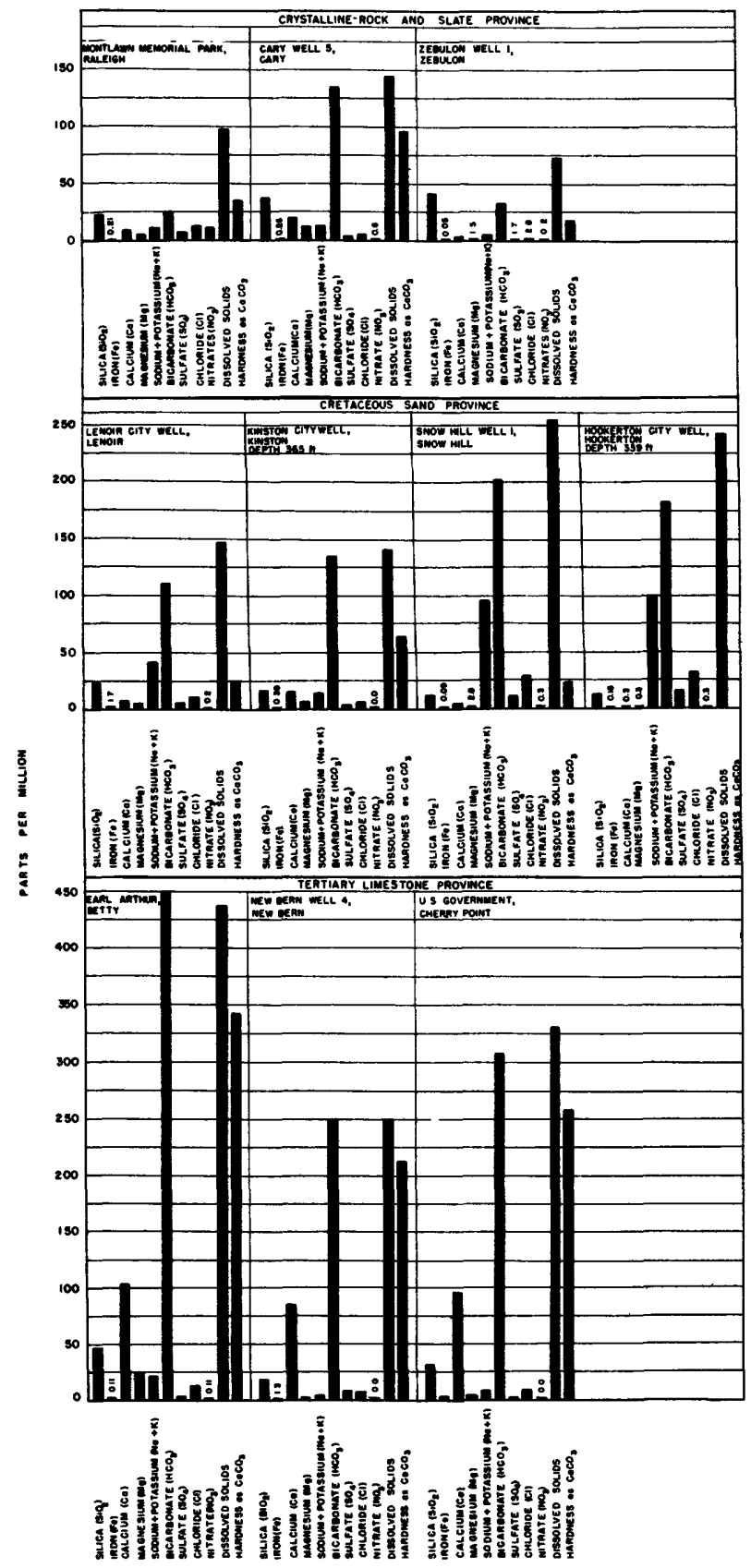

Figure 24. - Chemical character of selected ground water in Neuse River basin. 

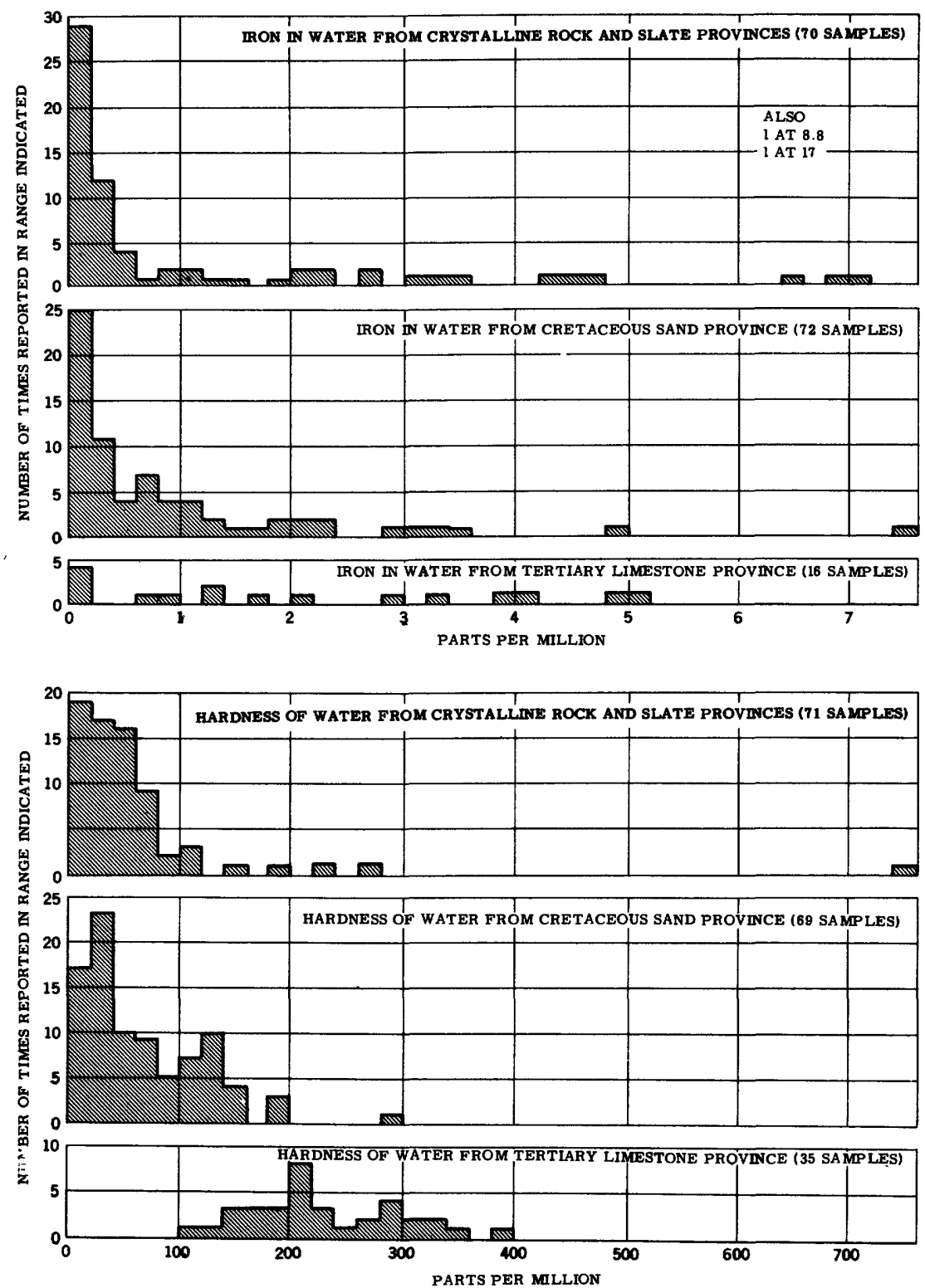

Figure 25.-Distribution graph of hardness and iron content of ground water in Neuse River basin. 
The intrusion of dikes and the growth of mineral veins may have caused fracturing in the surrounding rocks. Quartz veins are common in the slate and granite, and, because quartz is a brittle mineral, many large openings have developed in the veins as a result of earth movements. A well drilled into a quartz vein or into the fractured zone near a dike may yield a large amount of water.

Fractured zones usually are less resistant to erosion than is the relatively unfractured rock, allowing valleys and other low places to develop. Thus a well drilled in a low place has a greater chance of intersecting openings than a well on high ground; too, the natural drainage of ground water is toward valleys. Records of wells in the slate and granite indicate that most wells drilled in valleys are much more productive than wells drilled on hills.

The so-called shale rocks ( $B$ in pl, 2 ) are chiefly shale or claystone that has been so compacted and cemented that permeability is low. Ground water cannot move rapidly through the minute pores, most of the movement being through fractures and along bedding planes. The shale commonly yields less water than the granite and slate. The sandstone is a somewhat better producer.

Many wells in the shale have fairly good yields at first but become much less productive after a short time. Probably water in the pores near such wells is withdrawn quickly but the morement of recharge water from farther away is too slow to sustain the initial rate of production.

Depth and yield of wells. - Throughout the crystalline-rock province, most domestic supplies are obtained from dug or bored wells, which are generally extended down to hard rock. Such wells average about 40 feet in depth and furnish enough water for household use, except in very dry summers. A drilled well, located at a favorable place, generally will yield more water, inasmuch as it can be made deeper than the dug or bored wells. Because most of the usable ground water occurs in fractures formed near the surface, it is generally uneconomical to drill wells to depths greater than 300 feet. Because no sand or other loose material is ordinarily found in these rocks to fill up the well, an open-end well is usually satisfactory.

In the slate rocks and granite, the best wells may yield as much as $50 \mathrm{gpm}$, but wells yielding more than $25 \mathrm{gpm}$ are not common. The average yield of wells drilled in the shale rocks is only 10 or $15 \mathrm{gpm}$, but as much as $30 \mathrm{gpm}$ may be obtained from the more permeable sandstone or from fractured zones near dikes. 
Quality of water. - The rocks in the crystalline-rock provinces generally yield water of similar chemical character, and the analyses of water are summarized in table 9 . The dissolved-solids content in 68 water samples ranged from 43 to $1,460 \mathrm{ppm}$, the median being $108 \mathrm{ppm}$. The hardness ranged from 10 to $750 \mathrm{ppm}$ and the median was $46 \mathrm{ppm}$. The iron cnntent ranged from essentially zero to $17 \mathrm{ppm}$. Of 70 samples analyzed for iron content, 48 contained less than $1.0 \mathrm{ppm}$ ( 37 of them less than $0.30 \mathrm{ppm}$ ) and 22 contained more than $1.0 \mathrm{ppm}$. The approximate range in concentration of iron in the ground-water provinces is shown in figure 25. In the 68 samples the chloride content ranged from 2.5 to 815 ppm and the sulfate from 0.6 to $179 \mathrm{ppm}$, but few exceeded 20 and $17 \mathrm{ppm}$, respectively. Analyses showing very hard water and much dissolved mineral matter are generally of water from the shale rocks. Temperatures range from $60^{\circ} \mathrm{F}$ to $63^{\circ} \mathrm{F}$ for water from the slate rocks and granite, and from $58^{\circ} \mathrm{F}$ to $66^{\circ} \mathrm{F}$ for water from the shale rocks.

\section{SLATE PROVINCE}

Slate rocks ( $D$ in pl. 2) and parts of the Tuscaloosa, Black Creek, and Yorktown formations ( $E$ in pl.2) are included in the slate province. The rocks of this province are generally better water producers than those of the Piedmont but are not as good as the Coastal Plain aquifers farther to the southeast.

The slate rocks of zone $D$ are similar to those in zone $A$ of the Piedmont but the yield in wells are generally larger, the rocks apparently being more schistose and more highly fractured. The Coastal Plain beds are mostly unconsolidated clay or sandy clay but they include some sand beds of low permeability. Few are more than 100 feet thick.

Depth and yield of wells. - Small supplies for rural domestic use are generally obtained from dug or bored wells, but in the Coastal Plain driven wells, or well points, also are common. Such wells are rarely deeper than 50 feet. Larger supplies for municipal or industrial use may be obtained if wells are properly located and constructed. Where slate rocks are exposed, wells should be located in the manner already described for the Piedmont. Openend wells are satisfactory and generally need be no deeper than 300 feet.

In the Coastal Plain section of this area, good yields are obtained if sand strata are reached in drilling. Maximum yields are generally obtained if wells are drilled through the Coastal Plain strata and into the underlying slate rocks. If sand strata or other 
loose sediments are penetrated, a screen will prevent the entrance of such material into the well but will allow the water to enter and be added to the total supply. Open-end wells are satisfactory if they end in firm material. Most of the available water will be obtained within 300 feet of the surface.

Wells drilled in favorable places may yield 50 to $200 \mathrm{gpm}$. The best wells in this area have produced as much as $200 \mathrm{gpm}$ but such large yields generally decline slowly over a period of several years, the permeability of the rocks not being high enough to provide sufficient recharge to sustain heavy pumping.

Quality of water. - The chemical quality of the ground water in the crystalline rock and slate provinces has been discussed with that of the water of the Piedmont.

\section{CRETACEOUS SAND PROVINCE}

The Black Creek and Peedee formations of Late Cretaceous age are the chief aquifers in the Cretaceous sand province. Fine-to medium-grained sand layers alternate with beds of clay throughout the entire thickness of the Coastal Plain strata. Clay of the Yorktown formation is found near the surface in the northeast half of the province, and loose sand covers the surface in most of the province, but only small domestic water supplies can be obtained from these sources.

The sand layers that lie at greater depth are rechargedfrom precipitation on their outcrops to the northwest and constitute excellent artesian aquifers. The sand layers are generally clean and very permeable.

Depth and yield of wells. - Because water is withdrawn from layers of sand which alternate with beds of clay, a well is drilled through one or more sand layers depending on the amount of water required. Wells range in depth, therefore, from 100 to more than 600 feet, the aggregate yield generally increasing with depth.

It is necessary to install a screen or slotted pipe in each sand zone to allow water to enter the well. If only one sand layer is utilized, a maximum yield of 200 gpm may be expected, but properly developed wells getting water from several sand beds are capable of much larger yields. Yields in excess of $500 \mathrm{gpm}$ have been obtained from gravel-walled wells in this province, but properly screened and developed wells without gravel walls may give comparable results. 
Quality of water. - Generally the water from the Cretaceous sand province is of excellent chemical quality, suitable for most purposes with little or no treatment. Water from shallow wells in the southeastern half of the province may be hard, but deeper water is soft and resembles that from the northwestern half of the province. The hardness of water from the Cretaceous sand province generally ranges from 15 to 125 ppm and dissolved solids from 73 to $189 \mathrm{ppm}$. Sodium and bicarbonate ions predominate. The hardness of water in this province is shown in figure 25. Iron in 72 water samples from wells in this province ranged from 0.03 to $7.6 \mathrm{ppm}$, the median being $0.38 \mathrm{ppm}$.

\section{TERTIARY LIMESTONE PROVINCE}

The Tertiary limestone province consists of the shell limestone and interbedded sand layers of the Castle Hayne and Yorktown formations. There are some clay beds or other zones of low permeability in these strata that allow artesian conditions to develop. The limestone owes its exceptional permeability to the removal, by percolating waters, of much soluble material, thereby enlarging the openings and facilitating the movement of water.

Depth and yield of wells. - In most places the limestone is consolidated enough to allow the use of open-end wells. There are many places, however, where the aquifer is unconsolidated and gravelwalled wells or other screened wells are profitable. Wells are generally drilled to obtain water from several permeable layers, so that depths range from 100 to more than $300 \mathrm{feet}$, depending on the quantity of water desired and the thickness of the freshwater body. Yields of more than $500 \mathrm{gpm}$ are generally obtained from properly constructed wells in the Tertiary limestone province.

Quality of water. - The Tertiary limestone province yields water in which calcium bicarbonate predominates and which has a hardness ranging from 110 to $391 \mathrm{ppm}$. Ground water sampled in the province contained 0.07 to $5.2 \mathrm{ppm}$ of iron. In 37 water samples the chloride content ranged from 3.8 to $760 \mathrm{ppm}$, the median being 9.0 ppm.

\section{COMPOSITE' LLMESTONE.SAND PROVINCES}

The composite limestone-sand province is an intermediate zone in which adequate ground-water supplies may be obtained from the limestones of Tertiary age near the surface or from the sands of Cretaceous age beneath. 
Depth and yield of wells . - Generally the shell limestone of Tertiary age is less than 100 feet thick and only shallow wells obtain water from this source. Deeper wells may obtain water solely from the sands of Cretaceous age or may utilize the limestone aquifer also. Wells may, therefore, range in depth from less than 100 feet to more than 600 feet, the maximum depth being limited by the presence of salt water (fig. 23).

Yields and types of wells are comparable to those in the adjoining ground-water provinces. Some wells yielding more than 500 gpm obtain water from both aquifers.

Quality of water.-Ground water in the composite limestone-sand province resembles that from the Cretaceous sand and the Tertiary limestone provinces, depending on the source.

\section{WATER LEVELS}

Water levels in wells reflect the fluctuations of the water table. Although precipitation is the source of ground water, water levels in the Neuse River basin are not highest during the summer when rainfall is greatest. Generally, the water table is at its highest level in the spring. As crops and other vegetation begin to remove water from the soil, a deficiency in soil moisture develops. Rainfall reaching the ground must make up this deficiency before any can reach the water table. Because high summer temperatures cause high rates of evaporation, the ground-water reservoir is recharged during the summer only when rainfall is heavy or prolonged. Summer storms sometimes produce very heavy rains that cannot be quickly absorbed by the soil, and surface runoff is often great. During the summer, withdrawal of water for human use is also greater, whether for recreation, irrigation, or other uses.

It seems obvious that some few factors, such as high rate of evaporation and transpiration, large withdrawals, and the brevity of summer storms, either remove much ground water from storage or prevent effective ground-water recharge, so that water levels reach their lowest points at the end of the growing season.

During fall, winter, and early spring, fewer demands are made upon the ground-water reservoirs. Withdrawal is much less during these seasons, vegetation is not removing much.moisture from the soil, evaporation is at its lowest rate, and the winter rains are comparatively prolonged. Large amounts of precipitation percolate into the zone of saturation and ground-water levels rise to their highest stages of the year. 

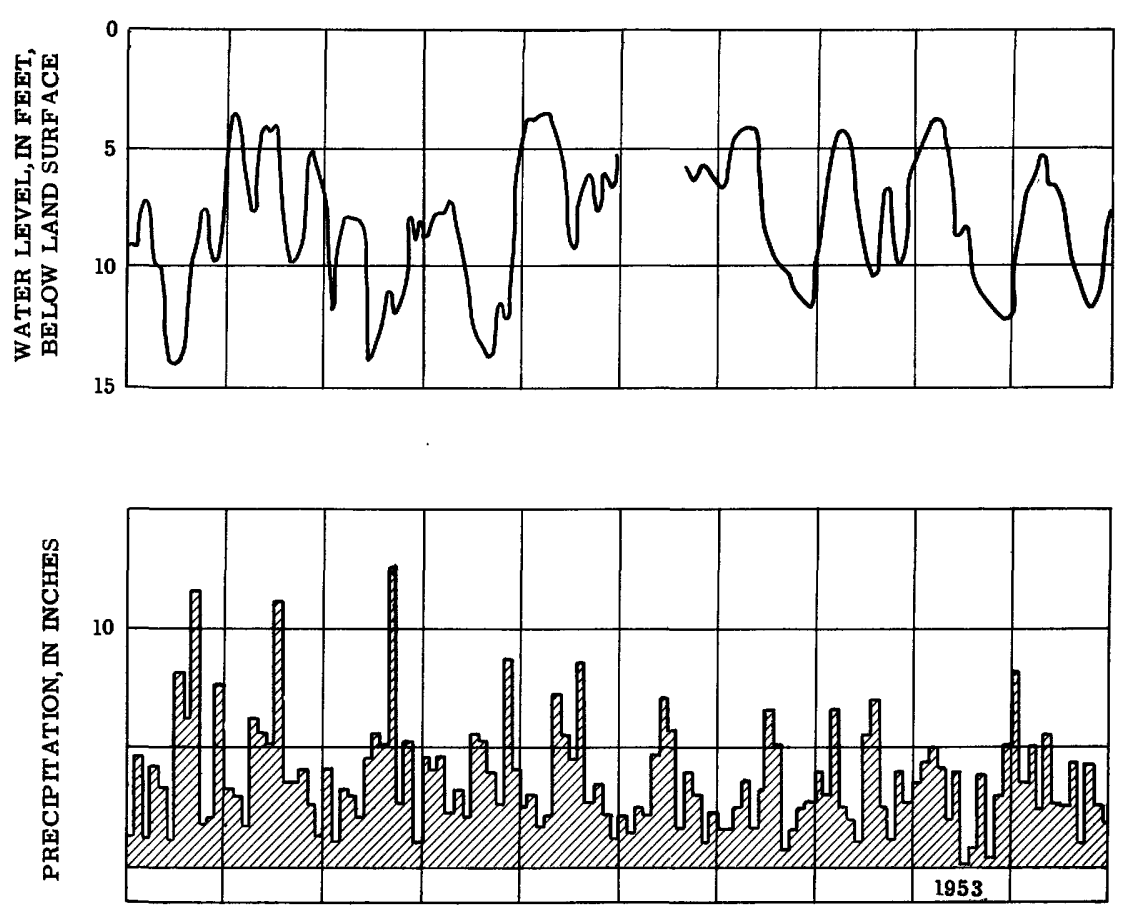

Figure 26. - Chart showing the fluctuation of the water level in a shallow observation well on the Fish dam property in northern Wake County near the gaging station on the Neuse River near Northside, N. C.

A hydrograph of one observation well in the Neuse River basin is compared with climatic data in figure 26. This illustration shows that water levels usually rise soon after a rainfall and then decline slowly thereafter.

Sometimes, drainage works are constructed to lower the water table permanently in swamps and meadow lands so that more valuable crops may be grown. In the Neuse River basin, such drainage projects have been effective locally but have not been extensive enough, as yet, to lower water levels over wide areas.

There is often some concern about falling water levels toward the end of the growing season when water levels are at their lowest stage of the year. There is seldom any occasion for comment when the water table is at the highest point of its cycle in the spring. Thus it may not be generally realized that the water table at any given time of year differs little from its stage at the same time in previous years. Periods of several years of persistently dry or persistently wet weather cause temporary downward or 
upward trends from year to year. However, where the ground water is not pumped heavily or otherwise discharged artifically (as through drainage ditches), these trends are not permanent, and over a long period of years the average ground-water levels change little.

\section{PUBLIC WATER-SUPPLY SYSTEMS}

There are 43 public water systems in the Neuse River basin; 9 use surface water and 34 use ground water. Location of the systems, the source of supply, the dissolved solids content, and hardness of the waters is shown in plate 3. A summary of chemical analyses of raw and treated waters for the water-supply systems in the basin is given in table 10. Additional pertinent data related to the systems in the basin are given in the following sections. The data on yields of wells are not strictly indicative of the productivity of the aquifers. Some reported yields were measured during short intensive pumping tests after the drilling of the wells and probably are larger than could be sustained over a long period; some yields represent pump capacity rather than maximum well yield, and so do not show the amount that could be pumped.

\section{APEX, WAKE COUNTY}

Ownership: Municipal. Population served: 1,084. Source: Reservoir on two unnamed streams forming a 35-acre lake. Treatment: Coagulation with alum, chlorination, rapid sand filtration, final adjustment of $\mathrm{pH}$ with lime. Rated capacity of filtration plant: 324,000 gpd. Raw-water storage: None. Finished-water storage: 100,000-gallon elevated tank. Location of filtration plant: 3 miles northeast of Apex. It was necessary to supplement the normal water source with water from nearby lakes in 1954.

\section{AYDEN, PITT COUNTY}

Ownership: Municipal. Population served: 2, 282. Source: 4 wells (Nos. 1-4; 155, 155, 450, and 505 feet deep. The yield is reported to be $150,250,350$, and $500 \mathrm{gpm}$. Well 1 pumped into 100,000-gallon reservoir and then into elevated tank for distribution. Wells 2-4 are pumped directly into mains for distribution. Treatment: None. Ground storage: 100,000-gallon reservoir. Elevated storage: 60, 000-gallon elevated tank. 
Table 10.-Chemical analyses of water from public

[Chemical constituents, in parts per million.

\begin{tabular}{|c|c|c|c|c|c|c|c|c|c|c|}
\hline Location & $\begin{array}{l}\text { Date } \\
\text { of } \\
\text { collection }\end{array}$ & Type & $\begin{array}{c}\text { Depth } \\
\text { of } \\
\text { well } \\
\text { (feet) }\end{array}$ & $\begin{array}{l}\text { Silica } \\
\left(\mathrm{SiO}_{2}\right)\end{array}$ & $\begin{array}{l}\text { lron } \\
(\mathrm{Fe})\end{array}$ & $\begin{array}{c}\text { Man- } \\
\text { ga- } \\
\text { nese } \\
(\mathrm{Mn})\end{array}$ & $\begin{array}{l}\text { Cal- } \\
\text { cium } \\
\text { (Ca) }\end{array}$ & $\begin{array}{l}\text { Mag- } \\
\text { ne- } \\
\text { sium } \\
(\mathrm{Mg})\end{array}$ & $\begin{array}{c}\text { Sodium } \\
\text { (Na) }\end{array}$ & $\begin{array}{c}\text { Potassium } \\
\text { (K) }\end{array}$ \\
\hline Apex. & $\begin{array}{|ll|}3 & 1952 \\
\end{array}$ & $\begin{array}{l}\text { R } \\
F\end{array}$ & . & $\begin{array}{l}5.5 \\
3.7\end{array}$ & 0.06 & $\begin{array}{r}0.00 \\
.08\end{array}$ & $\begin{array}{c}3.2 \\
17\end{array}$ & $\begin{array}{l}1.3 \\
1.4\end{array}$ & $\begin{array}{l}5 \\
5 .\end{array}$ & .0 \\
\hline yder & 9,1948 & $R$ & 155 & 19 & .68 & .07 & 42 & 2.9 & 9. & .2 \\
\hline Do. & Sept. 21,1951 & $\mathrm{R}$ & 450 & 11 & 3.3 & .00 & 12 & 1.7 & 11 & \\
\hline ailey. & July 22,1948 & R & 250 & 4.9 & 6.6 & .28 & 5.6 & 3.8 & 4. & 3 \\
\hline Do... & Mar. $\quad 4,1954$ & $\mathbf{F}$ & 155 & 24 & 4.0 & .00 & 4.1 & 4.2 & 14 & \\
\hline eaufort & 4,1955 & F & 348 & 36 & .09 & .00 & & 26 & 24 & 9.3 \\
\hline enson. & May 16,1947 & $\mathrm{R}$ & 550 & 12 & .09 & .00 & 17 & 6.9 & 54 & \\
\hline Do... & Apr. 23,1954 & $\mathrm{R}$ & 800 & 11 & .00 & .00 & 13 & 5.6 & 49 & \\
\hline Cary.... & Apr. 3. 1952 & $\mathbf{R}$ & 200 & 43 & .33 & .14 & 12 & 3.1 & 9. & .9 \\
\hline Do. & 2,1953 & R & 400 & 37 & 1.1 & .04 & 74 & 11 & 26 & \\
\hline Do.... & S ept. 18,1954 & $\mathrm{R}$ & 250 & 41 & 1.9 & .00 & 14 & 5.6 & 9.7 & 1.7 \\
\hline Do..... & Nov. 18,1954 & $\mathrm{R}$ & 500 & 47 & 1.8 & .00 & 22 & 5.1 & 15 & 1.6 \\
\hline Cherry Po & 5. 1953 & $\mathbf{R}$ & 250 & 31 & 2.6 & .00 & 85 & 2.3 & 8. & .1 \\
\hline Do.. & $\ldots$ & $\mathbf{F}$ & & 24 & .12 & .00 & 15 & 2.6 & 18 & \\
\hline Clayton. & May 20,1948 & $\mathrm{R}$ & 250 & 27 & .02 & .00 & 20 & 2.0 & 23 & \\
\hline Do... & Apr. 23,1954 & $\mathrm{R}$ & 125 & 30 & 1.1 & .00 & 12 & 4.5 & 12 & \\
\hline & & $\mathrm{R}$ & & 29 & .18 & .00 & 13 & 3.4 & 13 & \\
\hline Cove City. & 6. 1949 & $\mathrm{R}$ & 280 & 9.7 & .15 & .00 & 4.7 & 4.3 & 140 & \\
\hline Creed mc & 21,1954 & R & & 7.0 & .11 & .00 & 3.7 & .9 & 5 & .2 \\
\hline Do.. & & $\mathrm{F}$ & 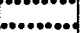 & 4.3 & .08 & .00 & 29 & 5.7 & & \\
\hline Jurham. & Jan. 31,1955 & $\mathbf{R}$ & ...... & 8.7 & .08 & .00 & 5.0 & 1.2 & 5.6 & 1.9 \\
\hline Do.... & $\ldots . . .$. & $\mathbf{F}$ & & 6.8 & .02 & .00 & 18 & 1.7 & 3.5 & 1.6 \\
\hline armvi & Nov. 11,1947 & R & 500 & 20 & .14 & .00 & 1.0 & 1.6 & 136 & \\
\hline & & $\mathbf{R}$ & 500 & 16 & .22 & .00 & 8.8 & 5.1 & 79 & \\
\hline Fountair & Jan. 12,1948 & $\mathrm{R}$ & 194 & 20 & .19 & .00 & 36 & 6.8 & 57 & \\
\hline Fremon & Apr. 26,1948 & $\mathbf{R}$ & 596 & 17 & .26 & .00 & 72 & 23 & 189 & \\
\hline Do..... & 3,1955 & $\mathrm{R}$ & 280 & 15 & .07 & .00 & 49 & 17 & 17 & 18 \\
\hline Garner.. & Jan. 21,1954 & $\mathbf{R}$ & & 33 & .13 & .00 & 9.7 & 5.4 & 9. & .8 \\
\hline Do. & $\ldots . .$. & $\mathbf{R}$ & 175 & 33 & .09 & .00 & 6.2 & 2.9 & 6. & .0 \\
\hline Do. & 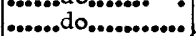 & $\mathrm{R}$ & 150 & 35 & .04 & .00 & 4.8 & 2.0 & 5. & .5 \\
\hline Goldsboro.. & Aug. 12,1950 & $\mathbf{R}$ & $\cdots$ & 13 & .06 & .00 & 2.8 & 1.2 & 5 & .1 \\
\hline Do. & ......do & $\mathbf{F}$ & . & 14 & .06 & .00 & 14 & 1,3 & 5. & .8 \\
\hline Grifton. & June 14,1954 & $R$ & 135 & 20 & .31 & .00 & 35 & 4,9 & 24 & 6.5 \\
\hline Hillsbor & Jan. 31,1955 & $\mathrm{R}$ & & 15 & .07 & .00 & 4.8 & 1.5 & 4.7 & .7 \\
\hline 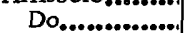 & & $\mathbf{F}$ & $\cdots$ & 14 & .12 & .00 & 12 & 1.5 & 4.2 & .4 \\
\hline Hookerton & 4.1955 & $\mathbf{R}$ & 380 & 13 & .12 & .00 & .2 & .2 & $84^{\circ}$ & 7.0 \\
\hline Kenly.. & 4,1947 & $\mathrm{R}$ & 96 & 12 & .49 & .12 & 8.7 & 13 & 33 & \\
\hline Do.. & $\ldots \ldots . .$. & $\mathrm{R}$ & 110 & 15 & .19 & .00 & 4.6 & 6.0 & 6. & .8 \\
\hline Do... & May 27,1954 & $\mathrm{R}$ & 200 & 22 & .66 & .00 & 9.8 & 2,8 & 13 & \\
\hline Kinston............ & Feb. 19,1951 & $\mathrm{R}$ & 375 & 13 & .17 & .00 & 7.6 & 2.7 & 40 & \\
\hline Do. & ......do... & $\mathrm{R}$ & 550 & 9.8 & .73 & .00 & 6.4 & 2.9 & 47 & \\
\hline Do... & 3,1955 & $\mathrm{R}$ & 435 & 11 & .22 & .00 & 9.6 & 6.6 & & 17 \\
\hline Knightdale....... & 9,1951 & $R$ & 92 & 48 & .35 & .00 & 9.0 & 3.0 & & 3 \\
\hline Do..... & June 12,1951 & $\mathrm{R}$ & 195 & 35 & .13 & .00 & 2,8 & .8 & 8. & .8 \\
\hline LaGrange......... & May 15,1947 & $R$ & 238 & 24 & 1.7 & .00 & 4.6 & 2.7 & 40 & \\
\hline ...... & 3,1955 & $\mathbf{R}$ & 321 & 26 & .31 & .00 & 2.4 & 1.2 & 32 & 6.4 \\
\hline Lucama.. & May 15,1947 & $\mathbf{F}$ & 190 & 42 & .88 & .00 & 27 & 3.7 & 6. & .5 \\
\hline 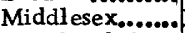 & 4,1954 & $\mathbf{F}$ & 86 & 35 & .10 & .00 & 7.6 & 2.9 & 6 & 8 \\
\hline Morehead City. & 4. 1955 & $\mathbf{F}$ & 230 & 40 & .17 & .00 & 96 & 5.4 & 8.8 & 4.8 \\
\hline & & . & & 41 & .10 & .00 & 84 & $11^{\circ-2}$ & 9.9 & 7.0 \\
\hline Mount Olive.... & Dec. 2,1946 & $\mathrm{R}$ & 170 & 32 & 1.4 & .08 & 7.9 & 1.0 & 9. & .5 \\
\hline Do.. & Aug. 21,1953 & $\mathbf{R}$ & 282 & 32 & .74 & .00 & 7.0 & 1.6 & 5. & \\
\hline New Berm.......... & Nov. 19,1952 & $\mathrm{R}$ & & 15 & 1.4 & .00 & $79^{\circ}$ & 1.8 & 14 & \\
\hline Do.... & June 10,1954 & $\mathrm{R}$ & 126 & 22 & 3.9 & .00 & 76 & 2.4 & 2. & \\
\hline Do.. & Nov, 19,1952 & $\mathbf{F}$ & & 15 & .14 & .00 & 23 & .5 & 74 & \\
\hline Pikeville........ & Oct. 19,1953 & $R$ & 87 & 13 & 1.4 & .00 & 3.4 & 1.5 & 3 & .6 \\
\hline Pink Hill... & 1,1955 & $\mathrm{R}$ & 220 & 12 & .26 & .00 & 48 & .7 & .9 & 1.0 \\
\hline Princeton.......... & 5. 1948 & $\mathrm{R}$ & 141 & 32 & .21 & .08 & 24 & 4.5 & 20 & \\
\hline Do................ & 7,1954 & $\mathrm{R}$ & 236 & 33 & .55 & .00 & 23 & 4.7 & 8. & .6 \\
\hline
\end{tabular}


water supplies in the Neuse River basin

Type: $R$, raw water; $F$, finished water]

\begin{tabular}{|c|c|c|c|c|c|c|c|c|c|c|c|}
\hline \multirow[b]{2}{*}{$\begin{array}{l}\text { Bicar- } \\
\text { bonate } \\
(\mathrm{HCO})\end{array}$} & \multirow[b]{2}{*}{$\begin{array}{l}\text { Car- } \\
\text { bonate } \\
\left(\mathrm{CO}_{3}\right)\end{array}$} & \multirow[b]{2}{*}{$\begin{array}{l}\text { Sulfate } \\
\left(\mathrm{SO}_{4}\right)\end{array}$} & \multirow[b]{2}{*}{$\begin{array}{l}\text { Chlo- } \\
\text { ride } \\
\text { (Cl) }\end{array}$} & \multirow[b]{2}{*}{$\begin{array}{l}\text { Fluo- } \\
\text { ride } \\
\text { (F) }\end{array}$} & \multirow[b]{2}{*}{$\begin{array}{l}\mathrm{Ni}- \\
\text { trate } \\
\left.\text { ( } \mathrm{NO}_{3}\right)\end{array}$} & \multirow{2}{*}{$\begin{array}{l}\text { Dissolved } \\
\text { solids } \\
\text { (residue } \\
\text { on evap- } \\
\text { oration } \\
\text { at } 180^{\circ} \mathrm{C} \text { ) }\end{array}$} & \multicolumn{2}{|c|}{$\begin{array}{c}\text { Hardness as } \\
\mathrm{CaCO}_{3}\end{array}$} & \multirow{2}{*}{$\begin{array}{c}\text { Specific } \\
\text { conduct- } \\
\text { ance } \\
\text { (micro- } \\
\text { mhos at } \\
25^{\circ} \mathrm{C} \text { ) }\end{array}$} & \multirow[b]{2}{*}{$\mathrm{pH}$} & \multirow[b]{2}{*}{$\begin{array}{l}\text { Color } \\
\text { (units) }\end{array}$} \\
\hline & & & & & & & $\mid \begin{array}{l}\text { Cal- } \\
\text { cium, } \\
\text { Mag- } \\
\text { nesium }\end{array}$ & $\begin{array}{l}\text { Non- } \\
\text { car- } \\
\text { bon- } \\
\text { ate }\end{array}$ & & & \\
\hline 9 & 0 & 6.5 & 6.5 & 0.1 & 0.8 & 40 & 13 & 6 & 52.4 & 6.7 & 25 \\
\hline 13 & 0 & 32 & 10 & .2 & 1.1 & 84 & 48 & 38 & $140^{\circ}$ & 6.7 & 2 \\
\hline 155 & 0 & 4.5 & 3.4 & .1 & .0 & 157 & 117 & 0 & & 7.6 & 12 \\
\hline 44 & 0 & 11 & 9.4 & .1 & .5 & 81 & 37 & 1 & 142 & 6.3 & 3 \\
\hline 39 & 0 & 2.4 & 2.9 & .1 & .0 & 43 & 30 & 0 & & 6.9 & 6 \\
\hline 39 & 0 & 11 & 8.8 & & 1.4 & 114 & 28 & 0 & 134 & 6.5 & 4 \\
\hline 383 & 0 & 2.6 & 13 & .3 & 1.3 & 369 & 278 & 0 & 588 & 7.2 & 12 \\
\hline 12.9 & 0 & 5.9 & 54 & .2 & .2 & 214 & 71 & 0 & & 7.8 & 3 \\
\hline 130 & 0 & 4.4 & 36 & .1 & .0 & 186 & 56 & 0 & 334 & 7.9 & 3 \\
\hline 68 & 0 & 3.6 & 3.2 & .1 & .1 & 108 & 43 & 0 & 128 & 6.7 & 2 \\
\hline 117 & 0 & 179 & 3.4 & .1 & .0 & 417 & 230 & 134 & 570 & 7.3 & 3 \\
\hline 87 & 0 & 8.6 & 3.5 & .0 & .2 & 127 & 57 & 0 & 172 & 6.6 & 10 \\
\hline 124 & 0 & 6.7 & 2.5 & .1 & .1 & 160 & 77 & 0 & 221 & 7.2 & 15 \\
\hline 275 & 0 & 1.0 & 8.5 & .3 & .0 & 283 & 222 & 0 & 447 & 7.1 & 18 \\
\hline 42 & 8 & 17 & 14 & .4 & .0 & 126 & 48 & 0 & 180 & 8.6 & 7 \\
\hline 72 & 0 & 11 & 20 & .0 & 12 & 158 & 58 & 0 & & 6.6 & 2 \\
\hline 63 & 0 & 7.7 & 9.0 & .1 & 2.6 & 113 & 48 & 0 & 157 & 6.6 & 2 \\
\hline 66 & 0 & 8.3 & 8.0 & .2 & 1.3 & 114 & 46 & 0 & 157 & 6.6 & 2 \\
\hline 365 & 13 & 1.4 & 7.0 & 1.0 & .2 & 369 & 29 & 0 & 602 & 8.3 & 9 \\
\hline 7 & 0 & 12 & 3.8 & .0 & 8 & 55 & 13 & 7 & 65.1 & 6.0 & 36 \\
\hline 18 & 4 & 76 & 6.2 & .0 & 1.2 & 146 & 96 & 74 & 233 & 9.2 & 5 \\
\hline 25 & 0 & 7.3 & 3.8 & .0 & .5 & 53 & 17 & 0 & 60.6 & 6.8 & 22 \\
\hline 22 & 4 & $27^{\circ}$ & 9.0 & .1 & 1.0 & 92 & 51 & 27 & $141^{\circ}$ & 9.0 & 7 \\
\hline 226 & 0 & 25 & 65 & .7 & .5 & 369 & 9 & 0 & & 7.8 & 15 \\
\hline 220 & 0 & 8.8 & 16 & .5 & .6 & 244 & 43 & 0 & ........ & 8.0 & 3 \\
\hline 137 & 0 & 7.1 & 86 & .2 & .4 & 285 & 118 & 6 & .............. & 7.6 & 0 \\
\hline 191 & 0 & 140 & 271 & .3 & .9 & 853 & 274 & 118 & ........... & 7.6 & 3 \\
\hline 199 & 0 & 28 & 41 & .0 & 1.5 & 280 & 191 & 28 & 490 & 7.7 & 5 \\
\hline 72 & 0 & 4.2 & 2.5 & .2 & .4 & 98 & $\begin{array}{r}46 \\
46\end{array}$ & 0 & 149 & 6.7 & 4 \\
\hline 40 & 0 & 2.4 & 3.2 & 1 & .5 & 81 & 27 & 0 & 79.2 & 6.6 & 4 \\
\hline 31 & 0 & 1.5 & 3.2 & .1 & .6 & 76 & 20 & 0 & 76.9 & 6.3 & 1 \\
\hline 16 & 0 & 3.5 & 4.2 & .0 & .5 & 50 & 12 & 0 & 51.2 & 6.6 & 17 \\
\hline 25 & 0 & 21 & 7.2 & .0 & .4 & 86 & 40 & 20 & 120 & 6.9 & 3 \\
\hline 189 & 0 & 3.5 & 5.5 & 3 & .1 & 193 & 108 & 0 & 315 & 8.1 & 3 \\
\hline 22 & 0 & 5.8 & 3.5 & .0 & .3 & 52 & 18 & 0 & 69.7 & 7.0 & 10 \\
\hline 19 & 7 & 14 & 4.2 & .0 & .0 & 75 & 35 & 8 & 102 & 9.2 & 10 \\
\hline 181 & 0 & 15 & 30 & .0 & .8 & 247 & 2 & 0 & 408 & 7.9 & 12 \\
\hline 20 & 0 & 6.4 & 72 & .1 & 27 & 194 & 75 & 59 & & 5.9 & 6 \\
\hline 18 & 0 & 3.2 & 14 & .1 & 16 & 82 & 36 & 21 & .......... & 6.2 & 3 \\
\hline 58 & 0 & 4.6 & 6.5 & .1 & 2.4 & 91 & 36 & 0 & 134 & 6.9 & 4 \\
\hline 127 & 0 & 3.1 & 6.0 & .2 & .3 & 138 & 30 & 0 & 227 & 7.7 & 3 \\
\hline 145 & 0 & 1.4 & 6.0 & .3 & .0 & 151 & 28 & 0 & 252 & 7.7 & 12 \\
\hline 156 & 0 & 3.5 & 2.2 & 1 & 1.0 & 153 & 51 & 0 & 254 & 8.0 & 8 \\
\hline 48 & 0 & 1.1 & 3.9 & .1 & 5.5 & 105 & 35 & 0 & 110 & 6.6 & 2 \\
\hline 29 & 0 & 1.1 & 2.6 & 1 & .4 & 68 & 10 & 0 & 58.0 & 6.0 & 3 \\
\hline 111 & 0 & 3.3 & 11 & .2 & .2 & 146 & 23 & 0 & & 7.4 & 37 \\
\hline 89 & 0 & 5.6 & 7.8 & .1 & 1.2 & 127 & 11 & 0 & 173 & 7.3 & 10 \\
\hline 100 & 0 & 4.9 & 6.0 & .4 & .1 & 148 & 83 & 1 & & 7.7 & 18 \\
\hline 45 & 0 & 1.5 & 4.8 & .1 & .4 & 81 & 31 & 0 & 96,3 & 6.4 & 3 \\
\hline 320 & 0 & 1.6 & 10 & .0 & 1.3 & 337 & 262 & 0 & 508 & 7.2 & 17 \\
\hline 321 & 0 & 1.4 & 9.5 & .0 & 1.3 & 336 & 256 & 0 & 513 & 7.2 & 13 \\
\hline 39 & 0 & 5.9 & 3.8 & .4 & .0 & 83 & 24 & 0 & ...... & 6.0 & 12 \\
\hline 32 & 0 & 2.9 & 4.0 & .1 & .1 & 73 & 24 & 0 & 76.3 & 6.2 & 4 \\
\hline 214 & 0 & 15 & 31 & .0 & .0 & 279 & 204 & 29 & 442 & 7.1 & 3 \\
\hline 239 & 0 & .2 & 6.5 & .1 & .3 & 237 & 199 & 4 & 388 & 7.3 & 5 \\
\hline 216 & 0 & 13 & 21 & .0 & .0 & 253 & 59 & 0 & 423 & 7.5 & 6 \\
\hline 12 & 0 & 6.7 & 3,8 & 1 & .2 & 41 & 15 & 5 & 44.5 & 5,6 & 6 \\
\hline 150 & 0 & 1.5 & 3.2 & .1 & .0 & 151 & 123 & 0 & 256 & 7.5 & 0 \\
\hline 123 & 0 & 13 & 4.6 & .1 & .0 & 159 & 78 & 0 & & 7.8 & 13 \\
\hline 97 & 0 & 11 & 2.5 & .2 & .4 & 139 & 77 & 0 & $189^{\circ}$ & 7.6 & 3 \\
\hline
\end{tabular}


Table 10.-Chemical analyses of water from public water

\begin{tabular}{|c|c|c|c|c|c|c|c|c|c|c|}
\hline Location & $\begin{array}{l}\text { Date } \\
\text { of } \\
\text { collection }\end{array}$ & Type & $\begin{array}{c}\text { Depth } \\
\text { of } \\
\text { well } \\
\text { (feet) }\end{array}$ & $\left|\begin{array}{l}\text { Silica } \\
\left(\mathrm{SiO}_{2}\right)\end{array}\right|$ & $\begin{array}{l}\text { Iron } \\
(\mathrm{Fe})\end{array}$ & $\mid \begin{array}{c}\text { Man- } \\
\text { ga- } \\
\text { nese } \\
(\mathrm{Mn})\end{array}$ & $\mid \begin{array}{l}\text { Cal- } \\
\text { cium } \\
\text { (Ca) }\end{array}$ & $\mid \begin{array}{c}\text { Mag- } \\
\text { ne- } \\
\text { sium } \\
(\mathrm{Mg})\end{array}$ & $\begin{array}{c}\text { Sodium } \\
(\mathrm{Na})\end{array}$ & $\begin{array}{c}\text { Potassium } \\
(\mathrm{K})\end{array}$ \\
\hline 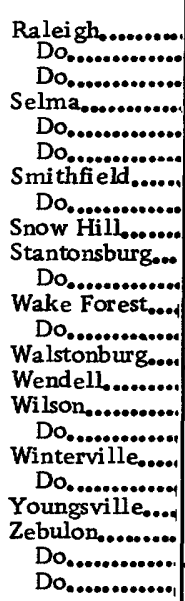 & 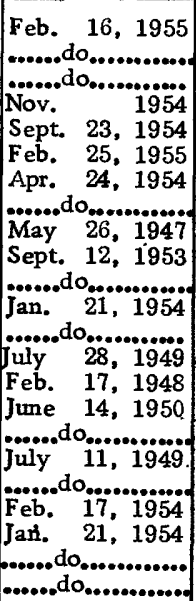 & $\begin{array}{l}R \\
R \\
F \\
R \\
R \\
F \\
R \\
F \\
R \\
R \\
R \\
R \\
F \\
R \\
R \\
R \\
F \\
R \\
R \\
F \\
R \\
R \\
F\end{array}$ & 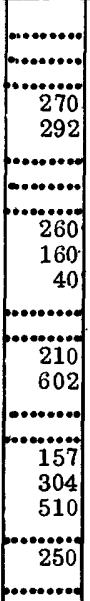 & $\begin{array}{c}2.4 \\
11 \\
7.1 \\
27 \\
28 \\
28 \\
16 \\
13 \\
11 \\
24 \\
20 \\
9.4 \\
12 \\
26 \\
38 \\
7.6 \\
8.3 \\
31 \\
28 \\
28 \\
11 \\
28 \\
9.5\end{array}$ & $\begin{array}{c}0.01 \\
.03 \\
.02 \\
3.8 \\
1.1 \\
.39 \\
.08 \\
.03 \\
.09 \\
.38 \\
.90 \\
.14 \\
.10 \\
.47 \\
.02 \\
.21 \\
.06 \\
1.5 \\
2.3 \\
.12 \\
.11 \\
.15 \\
.15\end{array}$ & $\begin{array}{l}0.00 \\
.00 \\
.00 \\
.60 \\
.40 \\
.00 \\
.00 \\
.00 \\
.00 \\
.01 \\
.01 \\
.00 \\
.00 \\
.04 \\
.00 \\
.00 \\
.00 \\
.07 \\
.00 \\
.00 \\
.00 \\
.00 \\
.00\end{array}$ & $\begin{array}{c}3.6 \\
3.2 \\
11 \\
19 \\
18 \\
18 \\
4.9 \\
17 \\
4.4 \\
20 \\
18 \\
2.2 \\
17 \\
8.7 \\
3.6 \\
2.3 \\
14 \\
69 \\
73 \\
18 \\
2.4 \\
5.7 \\
2.9\end{array}$ & $\begin{array}{r}0.7 \\
1.5 \\
1.4 \\
5.8 \\
3.2 \\
4.4 \\
1.9 \\
2.6 \\
2.8 \\
6.8 \\
6.9 \\
.5 \\
.8 \\
5.2 \\
.7 \\
1.1 \\
1.4 \\
2.9 \\
1.7 \\
6.6 \\
.3 \\
1.3 \\
.6\end{array}$ & $\begin{array}{r}4.3 \\
4.3 \\
4.9 \\
12 \\
12 \\
29 \\
7 \\
17 \\
91 \\
40 \\
48 \\
6 . \\
6 . \\
41 \\
8 . \\
5 \\
13 \\
8 . \\
8 . \\
11 \\
6 . \\
6 \\
12\end{array}$ & 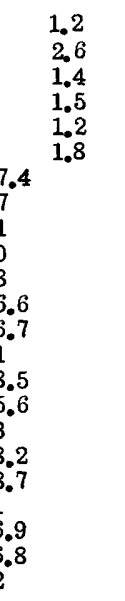 \\
\hline
\end{tabular}

BAILEY, NASH COUNTY

Ownership: Municipal. Population served: 808 . Source: 3 wells (Nos. 1, 3, and 4); 250, 250, and 155 feet deep. The yield is reported to be 30,80 , and $80 \mathrm{gpm}$. Treatment: Wells 1 and 3 , no treatment. Well 4, addition of Calgon for corrosion control, and chlorination. Ground storage: None. Elevated storage: 100, 000gallon elevated tank.

\section{BEAUFORT, CARTARET COUNTY}

Ownership: Carolina Water Co. Population served: 4, 390 . Source: 3 wells (Nos. 1, 2, and 3); 300, 400, and 348 feet deep. Well 3 is reported to yield $400 \mathrm{gpm}$. Wells are located near the elevated tank and water is pumped directly into the mains and the elevated tank. Treatment: None. Ground storage: None. Elevated storage: 100,000-gallon elevated tank. 
supplies in the Neuse River basin-Continued

\begin{tabular}{|c|c|c|c|c|c|c|c|c|c|c|c|}
\hline \multirow{2}{*}{$\begin{array}{l}\text { Bicar- } \\
\text { bonate } \\
\left(\mathrm{HCO}_{3}\right)\end{array}$} & \multirow[b]{2}{*}{$\begin{array}{r}\text { Car- } \\
\text { bonate } \\
\left(\mathrm{CO}_{3}\right)\end{array}$} & \multirow[b]{2}{*}{$\begin{array}{l}\text { Sulfate } \\
\left(\mathrm{SO}_{4}\right)\end{array}$} & \multirow{2}{*}{$\begin{array}{l}\text { Chlo- } \\
\text { ride } \\
\text { (Cl) }\end{array}$} & \multirow{2}{*}{$\begin{array}{l}\text { Flua- } \\
\text { ride } \\
(\mathrm{F})\end{array}$} & \multirow[b]{2}{*}{$\begin{array}{c}\mathrm{Ni}- \\
\text { trate } \\
\left(\mathrm{NO}_{3}\right)\end{array}$} & \multirow{2}{*}{$\begin{array}{l}\text { Dissolved } \\
\text { solids } \\
\text { (residue } \\
\text { on evap- } \\
\text { oration } \\
\text { at } 180^{\circ} \mathrm{C} \text { ) }\end{array}$} & \multicolumn{2}{|c|}{$\begin{array}{c}\text { Hardness as } \\
\mathrm{C}_{2} \mathrm{CO}_{3}\end{array}$} & \multirow{2}{*}{$\begin{array}{l}\text { Specific } \\
\text { conduct- } \\
\text { ance } \\
\text { (micro- } \\
\text { mhos at } \\
25^{\circ} \mathrm{C} \text { ) }\end{array}$} & \multirow[b]{2}{*}{$\mathrm{pH}$} & \multirow[b]{2}{*}{$\begin{array}{l}\text { Color } \\
\text { (units) }\end{array}$} \\
\hline & & & & & & & $\mid \begin{array}{c}\text { Cal- } \\
\text { cium } \\
\text { Mag- } \\
\text { nesium }\end{array}$ & $\begin{array}{l}\text { Non- } \\
\text { car- } \\
\text { bon- } \\
\text { ate }\end{array}$ & & & \\
\hline 17 & 0 & 5.6 & 3.2 & 0.0 & 0.0 & 40 & 12 & & 48.1 & & 23 \\
\hline 17 & 0 & 5.8 & $\begin{array}{l}3.2 \\
3.2\end{array}$ & .0 & .0 & 50 & 14 & 0 & $\begin{array}{l}40.1 \\
50.8\end{array}$ & 6.7 & 33 \\
\hline 20 & 0 & 23 & 5.5 & .2 & .1 & 69 & 33 & 17 & 100 & 7.5 & 3 \\
\hline 87 & 0 & 17 & 8.8 & .1 & .3 & 142 & 71 & 0 & 209 & 6.8 & 2 \\
\hline 65 & 0 & 27 & 3.0 & .1 & .9 & 130 & 59 & 5 & 178 & 6.8 & 5 \\
\hline 112 & 0 & 22 & 7.5 & .0 & .1 & 169 & 64 & 0 & 243 & 8.1 & 7 \\
\hline 24 & 0 & 5.1 & 6.5 & .1 & 2.3 & 59 & 20 & 0 & 75.6 & 6.6 & 19 \\
\hline 46 & 0 & 40 & 7.0 & .1 & 1.5 & 125 & 53 & 15 & 194 & 7.8 & 3 \\
\hline 204 & 0 & 11 & 28 & .4 & .3 & 255 & 22 & 0 & & 7.9 & 3 \\
\hline 171 & 0 & 9.0 & 11 & ? & .2 & 204 & 78 & 0 & 325 & 7.2 & 4 \\
\hline 178 & 0 & 11 & 13 & .2 & .5 & 211 & 73 & 0 & 356 & 7.4 & 3 \\
\hline 10 & 0 & 6.8 & 4.2 & .0 & .8 & 48 & 8 & 0 & 49.0 & 6.3 & 25 \\
\hline 10 & 0 & 44 & 4.0 & .0 & .8 & 92 & 46 & 38 & 136 & 6.3 & 5 \\
\hline 142 & 0 & 5.5 & 6.4 & .3 & .4 & 164 & 43 & 0 & 248 & 7.0 & 3 \\
\hline 29 & 0 & & 28 & .1 & 2.0 & 75 & 12 & 0 & & 6.2 & 5 \\
\hline 15 & 0 & 2.9 & 4.9 & .0 & .3 & 40 & 10 & 0 & 48.1 & 6.7 & 28 \\
\hline 34 & 0 & 30 & 6.5 & $\bullet$ & .8 & 92 & 41 & 13 & 155 & 7.9 & 4 \\
\hline 227 & 0 & 2.4 & 9.2 & 7 & .1 & 237 & 184 & 0 & 371 & 7.2 & 2 \\
\hline 213 & 0 & 8.9 & 17 & & .2 & 249 & 189 & 15 & 387 & 7.3 & 2 \\
\hline 95 & 0 & 12 & 3.2 & . & .1 & 131 & 72 & 0 & 187 & 7.0 & 4 \\
\hline 11 & 0 & 7.3 & 3. & 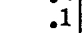 & .6 & 45 & 7 & 0 & 45.5 & 6.1 & 26 \\
\hline 31 & 0 & 2.9 & 3. &. & .8 & 77 & 20 & 0 & 79.3 & 6.0 & 4 \\
\hline 0 & 0 & 29 & 4.2 & -1 & .6 & 62 & 10 & 10 & 98.1 & 4,5 & 7 \\
\hline
\end{tabular}

BENSON, JOHNSTON COUNTY

Ownership: Municipal. Population served: 2,220. Source: 3 wells (Nos. 1, 2, and 3); 550, 717, and 800 feet deep. The yield is reported to be 200,140, and $15 \mathrm{gpm}$. Treatment: None. Ground storage: 100,000-gallon reservoir. Elevated storage: 100,000gallon elevated tank.

CARY, WAKE COUNTY

Ownership: Municipal. Population served: 1,768. Source: 11 wells (Nos. 1-3 and 5-12); 320, 220, 320, 250, 200, 405, 300, $400,300,402$, and 500 feet deep. The total yield of all wells is reported to be $532 \mathrm{gpm}$. All wells are pumped into distribution system at point of well location. Treatment: None. Ground storage: None. Elevated storage: 100,000-gallon elevated tank. 
CHERRY POINT, CRAVEN COUNTY

Ownership, U. S. Government. No information available as to population served. Source: Wells.

\section{CLAYTON, JOHNSTON COUNTY}

Ownership: Municipal. Population served: 2,500. Source: 9 wells (Nos. 1-9), 185, 225, 225, 250, 210,485, 225, 185, and 250 feet deep. The total yield of all wells is reported to be 341 gpm. Wells 1, 2, and 6 are pumped into ground reservoir and and then into system. All other wells are pumped into distribution system. Treatment: None. Ground storage: 100,000-gallon reservoir. Elevated storage: 100,000-gallon elevated tank.

\section{COVE CITY, CRAVEN COUNTY}

Ownership: Wells-Oates Lumber Co. Population served: 465. Source: 1 well, 280 feet deep. Treatment: None. Ground storage: None. Elevated storage: None.

\section{CREEDMOOR, GRANVILLE COUNTY}

Ownership: Municipal. Population served: 2, 075. Source: Ledge Creek impounded in lake with capacity of 120 million gallons. Treatment: Coagulation with alum, carbon, and lime; rapid sand filtration; adjustment of $\mathrm{pH}$ with lime. Rated capacity of filtration plant: 140, 000 gpd. Ground storage: 52, 000-gallon clear well. Elevated storage: 68,000-gallon elevated tank. Location of filtration plant: 1 mile west of Creedmoor on Camp Butner Road.

\section{DURHAM, DURHAM COUNTY}

Ownership: Municipal. Population served: about 79,000. Source: Flat River impounded in Lake Michie, about 15. miles northwest of the city. Treatment: Partial aeration, breakpoint chloripation, coagulation with alum and lime, sedimentation, rapid sand filtration, and final adjustment of $\mathrm{pH}$ with lime. Activated carbon used occasionally for taste and odor control. Rated capacity of treatment plant: $15.56 \mathrm{mgd}$. Raw-water storage: Impounding reservoir, 4, 500 million gallons. Finished-water storage 5 clear wells, 4.5 million gallons; 1 elevated tank, 1.5 million gallons; 1 elevated reservoir, 3 million gallons. Quantity of water used during: 1954: 3, 176. 6 million gallons. Maximum daily rate: $5.87 \mathrm{mgd}$. 
FARMVILL, PITT COUNTY

Ownership: Municipal. Population served: 3,535. Source: 3 wells (Nos. 3, 4, and 5), 500, 300, and 500 feet deep. The yield is reported to be 350,150 , and $500 \mathrm{gpm}$. Treatment: None. Ground storage: 100,000-gallon reservoir. Elevated storage: 300,000 -gallon elevated tank.

\section{FoUntain, PITt CoUnTy}

Ownership: Municipal. Population served: 525. Source: 1 well, 194 feet deep. The yield is reported to be $60 \mathrm{gpm}$. Treatment: None. Ground storage: None. Elevated storage: 75,000-gallon elevated tank.

\section{FREMONT, WAYNE COUNTY}

Ownership: Municipal. Population served: 1,395. Source: 2 wells (1 and 2), 596 and 252 feet deep. The yield is reported to be 94 and $90 \mathrm{gpm}$. Treatment: None. Ground storage: None. Elevated storage: 100,000-gallon elevated tank.

GARNER, WAKE COUNTY

Ownership: Municipal. Population served: 710. Source: 6 wells (Nos. 1-6), 135 to 175 feet deep. Treatment: None. Ground storage: None. Elevated storage: A 50,000-gallon elevated tank to be installed prior to June 30, 1955 .

\section{GOLDSBORO, WAYNE COUNTY}

Ownership: Municipal. Population served: about 25,000. Source Little River. Treatment, Prechlorination, coagulation with alum and lime, sedimentation, rapid sand filtration, postchlorination, and final adjustment of $\mathrm{pH}$ with lime. Rated capacity of treatment plant: 3 mgd. Raw-water storage: None. Finished-water storage: 500,000-gallon clear well; 1-million-gallon elevated tank. Location of treatment plant: 2 miles northwest of Goldsboro on the south bank of Little River.

\section{GRIFTON, PITT COUNTY}

Ownership: Municipal. Population served: 1,700 . Source 3 wells $(1,2$, and 3$)$, each well 135 feet deep. The total yield is 
reported to be $541 \mathrm{gpm}$. Treatment None. Ground storage:None. Elevated storage: 60,000-gallon elevated tank.

\section{HILLSBORO, ORANGE COUNTY}

Ownership: Municipal. Population served: 2,360. Source: Eno River. Treatment: Coagulation with alum, rapid sand filtration, postchlorination, and final adjustment of $\mathrm{pH}$ with lime. Rated capacity of filtration plant: 500,000 gpd. Raw-water storage: None. Finished-water storage: 50,000-gallon clear water well;200,000gallon standpipe; and 20,000-gallon elevated tank. Location of filtration plant: 2 miles west of Hillsboro. Plans have been made to build a 24-million-gallon impounding reservoir on Eno River.

HOOKERTON, GREENE COUNTY

Ownership: Municipal. Population served: 350. Source: 1 well, 380 feet deep. The yield is reported to be $120 \mathrm{gpm}$. Treatment: None. Ground storage: None. Elevated storage: 75,000-gallon elevated tank.

\section{KENLY, JOHNSTON COUNTY}

Ownership: Municipal. Population served: 1,520. Source: 3 wells (Nos. 1, 2, and 3), 96, 110, and 200 feet deep. The yield is reported to be 90,70 , and $200 \mathrm{gpm}$. Treatment: None. Ground storage: None. Elevated storage: 100,000-gallon elevated tank.

\section{KINSTON, LENOIR COUNTY}

Ownership: Municipal. Population served: 27,500. Source: 5 wells (Nos. 1-5), 361, 369, 365, 552, and 435 feet deep; 3 artesian flowing wells (Hillcrest group); 350 to 390 feet deep. The yield of the 5 wells is reported to be: $900,690,460,900$, and 980 gpm. The flow of the artesian group is $150 \mathrm{gpm}$. Treatment; The water from the 5 wells is chlorinated before entering the distribution system. Water from the Hillcrest wells flows into a reservoir and is then pumped into the distribution system. Ground storage: 2 reservoirs, 1,000,000 and 250,000 gallons. Elevated storage: 50,000-gallon elevated tank. 
KNIGHTDALE, WAKE COUNTY

Ownership: Municipal. Population served: 620. Source: 2 wells ( 1 and 2), 195 and 95 feet deep. The yield of the 2 wells is reported to be 82 and $22 \mathrm{gpm}$. Treatment: Chlorination. Ground storage: None. Elevated storage: 75,000 gallon elevated tank.

\section{LA GRANGE, LENOIR COUNTY}

Ownership: Municipal. Population served: 1,800. Source 2 wells ( 1 and 2), 238 and 321 feet deep. Well 1 used for stand-by. The yield of the 2 wells is reported to be 300 and $250 \mathrm{gpm}$. Treatment: None. Ground storage: None. Elevated storage: 90,000gallon elevated tank.

\section{LUCAMA WILSON COUNTY}

Ownership: Municipal. Population served:400. Source: 1 well, 190 feet deep. The yield of the well is reported to be $50 \mathrm{gpm}$. Treatment: Aeration (over coke trays), coagulation with lime, chlorination, and rapid sand filtration. Ground storage: 3,000gallon concrete reservoir. Elevated storage: 100,000-gallon elevated tank.

\section{MIDDLESEX, NASH COUNTY}

Ownership: Municipal. Population served: 525. Source:2 wells ( 1 and 2), 86 and 74 feet deep. The yield of the 2 wells is reported to be $30 \mathrm{gpm}$ each. Treatment: Addition of Calgon for corrosion control. Ground storage: None. Elevated storage: 30,000gallon elevated tank.

\section{MOREHEAD CITY, CARTERET COUNTY}

Ownership: Carolina Water Company. Population served: 5,444. Source: 6 wells (Nos. 1-6), 250, 525, 129, 247, 250, and 230 feet deep. Well number 6 is reported to yield $365 \mathrm{gpm}$. Treatment: Chlorination. Ground storage: None. Elevated storage: 65,000gallon elevated tank.

\section{MOUNT OLIVE, WAYNE COUNTY}

Ownership: Municipal. Population served: 4,000. Source: 4 wells (Nos. 1-4) 135, 170, 175, and 282 feet deep. The yield 
of the wells is reported to be $90,160,150$, and $800 \mathrm{gpm}$. Treatment: Chlorination. Ground storage: 2 concrete reservoirs, 100, 000 gallon and 15, 000 gallon. Elevated storage: 75, 000 -gallon elevated tank.

\section{NEW BERN, CRAVEN COUNTY}

Ownership: Municipal. Population served: 17,380. Source: 12 wells (Nos. 1-12), 90 to 115 feet deep. The total yield of the wells is reported to be $3,100 \mathrm{gpm}$. Treatment: Softening with zeolite, ammoniation, and chlorination. Rated capacity of treatment plant: $2 \mathrm{mgd}$. Raw-water storage: None. Ground storage: 300,000 -gallon reservoir. Elevated storage: 100,000-gallon elevated tank.

\section{PINK HILL, LENOIR COUNTY}

Ownership: Municipal. Population served: 450. Source: 1 well, 220 feet deep. The yield of the well is reported to be 250 gpm. Treatment: None. Ground storage: None. Elevated storage: 100,000 -gallon elevated tank.

PIKEVILLE, WAYNe COUNTY

Ownership: Municipal. Population served: 500. Source: 5 wells (Nos. 1-5), 257, 22, 20, 87, and 90 feet deep. The yield is reported to be $10,15,15,100$, and $100 \mathrm{gpm}$. Treatment: Addition of Calgon for corrosion control and chlorination. Ground storage: 3 clear water wells. Elevated storage: 75,000-gallon elevated tank.

\section{PRINCETON, JOHNSTON COUNTY}

Ownership: Municipal. Population served: 655 . Source: 2 wells ( 1 and 2), 141 and 236 feet deep. The yield is reported to be 60 and $80 \mathrm{gpm}$. Treatment: None. Ground storage: 1 clear water well. Elevated storage: 75,000-gallon elevated

\section{RALEIGH, WAKE COUNTY}

Ownership: Municipal. Population served: abrut 73,500. Source: Walnut Creek impounded in Lakes Raleigh and Johnson. Swift Creek impounded in Rands Mill reservoir. Treatment: Coagulation 
with alum, ammoniation (ammonium sulfate), prechlorination, sedimentation, addition of activated carbon for control of taste and odor, rapid sand filtration, adjustment of $\mathrm{pH}$ with lime, and postchlorination. Rated capacity of treatment plant: 13, 000, 000 gpd. Ground storage: 2 clear wells, 2 million and 2 million gallons. Elevated storage: 3 elevated tanks; $100,000,600,000$, and 750,000 gallons. Location of treatment plant: 1 mile south of Raleigh on the old Fayetteville Road.

\section{SELMA, JOHNSTON COUNTY}

Ownership: Municipal. Population served: 2,600. Source: 5 wells (Nos. 3-7), 181, 305, 300, 291, and 275 feet deep. The yield is reported to be $180,350,300,100,200 \mathrm{gpm}$. Treatment: Filtration by pressure, adjustment to $\mathrm{pH} 9.2$ with caustic soda, and chlorination. Ground storage: 8,000-gallon reservoir. Elevated storage: 75,000-gallon elevated tank.

\section{SMITHFIELD, JOHNSTON COUNTY}

Ownership: Municipal. Population served: 5,700. Source: Neuse River. Treatment: Coagulation with alum and soda ash, prechlorination, addition of activated carbon for control of taste and odor, rapid sand filtration, adjustment of $\mathrm{pH}$ with lime, and postchlorination. Rated capacity of treatment plant: $1 \mathrm{mgd}$. Ground storage: 200, 000 gallon clear water well. Elevated storage: 2 elevated tanks; 100,000 and 300,000 gallons. Location of treatment plant: Northwest Smithfield on Neuse River.

\section{SNOW HILL, GREENE COUNTY}

Ownership: Carolina Water Company. Population served: 1, 000. Source: 1 well 260 feet deep. The yield is reported to be $340 \mathrm{gpm}$. Treatment: None. Ground storage: None. Elevated storage: 75, 000-gallon elevated tank.

\section{STANTONSBURG, WILSON COUNTY}

Ownership: Municipal. Population served: 750 . Source: 2 wells ( 1 and 3 ), 165 and 150 feet deep. The yield is reported to be 300 and $80 \mathrm{gpm}$. Treatment: None. Ground storage: None. Elevated storage: 30,000 -gallon elevated tank. 
WAKE FOREST, WAKE COUNTY

Ownership: Municipal. Population served: 4,400. Source: Smith Creek and Alston Branch impounded. Treatment: Coagulation with alum and lime, rapid sand filtration, and chlorination. Rated capacity of filtration plant: $450,000 \mathrm{gpd}$.

\section{WALSTONBURG, GREENE COUNTY}

Ownership: Municipal. Population served: 250. Source: 1 well 210 feet deep. Treatment: None. Ground storage: None. Elevated storage: 75,000-gallon elevated tank.

\section{WENDELL, WAKE COUNTY}

Ownership: Municipal. Population served: 1,690. Source: 4 wells (Nos. 1-4), 301, 602, 301, and 100 feet deep. The yield is reported to be $40,30,20$, and $60 \mathrm{gpm}$. Treatment: None. Ground storage: None. Elevated storage: 100,000-gallon elevated tank.

\section{WIISON, WILSON COUNTY}

Ownership: Municipal. Population served: 25,000. Source: Contentnea Creek and Toisnot Swamp. Treatment: Prechlorination, coagulation with alum and (if necessary) lime, sedimentation, rapid sand filtration, ammoniation, addition of Calgon for corrosion control, postchlorination, and adjustment of $\mathrm{pH}$ with lime. Rated capacity of treatment plant: $4 \mathrm{mgd}$. Raw-water storage: None. Finished-water storage: 1 reservoir, 2 million gallons; 1 elevated tank, 1 million gallons. During dry periods supply is supplemented from Tar River. One well has been drilled to be used as emergency supply.

\section{WINTERVILLE, PITT COUNTY}

Ownership: Municipal. Population served: 1,000. Source: 2 wells; 157 and 304 feet deep. The yield is reported to be 80 and $300 \mathrm{gpm}$. Treatment: Well 1, softening with zeolite and filtration; well 2, no treatment. Ground storage: None. Elevated storage: 75,000-gallon elevated tank. 


\section{YOUNGSULLE, FRANKLIN COUNTY}

Ownership: Municipal. Population served: 660. Source: 1 well, 300 feet deep. The yield is reported to be $75 \mathrm{gpm}$. Treatment: Addition of Calgon for corrosion control. Ground storage: None. Elevated storage: 75,000-gallon elevated tank.

ZEBULON, WAKE COUNTY

Ownership: Municipal. Population served: 1,486. Source: 4 wells (Nos. 1-4), 312, 250, 190, and 150 feet deep. The yield is reported to be $100,45,90$, and $50 \mathrm{gpm}$. Supplemental supply: Little River. Treatment: Wells, none. All wells pumped directly into distribution system. Little River. Coagulation with lime and alum, rapid sand filtration, and chlorination. Rated capacity of treatment plant: 200,000 gpd. Ground storage: 100,000-gallon clear well. Elevated storage: 100,000-gallon elevated tank.

\section{PRESENT WATER USE}

Water uses are classified in many ways; in this report they are considered to be of either the withdrawal or the nonwithdrawal type. Withdrawal uses are those that remove, or divert, water from its natural medium and transport it elsewhere. . Surface water that is withdrawn for most uses is usually returned in essentially undiminished quantity to the stream from which it was withdrawn. Thus the same water may be used many times if its quality has not been too greatly impaired. On the other hand, water withdrawn for irrigation, and distributed by sprinkler irrigation systems, as in North Carolina, is almost if not completely consumed. Irrigation, waterpower, and domestic, municipal, and industrial uses are withdrawal uses. The uses of ground water are all of the withdrawal type. The total withdrawal of surface water for all uses, except water power, probably is in the order of $200 \mathrm{mgd}$. Total withdrawals of ground water aggregate about $80 \mathrm{mgd}$.

Nonwithdrawal uses do not require diversion. Navigation, waste disposal, and most uses for recreation and for conservation of wildlife are examples of nonwithdrawal uses.

PRIVATE INDUSTRIAL SUPPLIES

Most industries in the Neuse River basin use some water from public water-supply systems, but estimates of the quantities of 
water used were not available. Streamflow is used at various points in the basin for water power to operate grist mills and electric power plants, for cooling water in steam-electric plants and other plants using steam power, and for processing textile products. Of the water withdrawn from streams for these uses, the greater part is returned to the stream from which it is withdrawr. Reliable estimates of the volumes of streamflow withdrawn for industrial use are not available, but the total volume is probably in the order of $150 \mathrm{mgd}$.

Textile plants are the greatest users of ground water in the Neuse River basin. Most of these plants use ground water for drinking and some other uses, but many use ground water for all or most of their operations. Many food processing plants and several smaller industries use wells as a source of water supply. Industrial use of ground water in the basin is estimated to be about $30 \mathrm{mgd}$.

\section{PUBLIC SUPPLIES}

The 33 public water-supply systems using ground water in the Neuse River basin use an estimated $16 \mathrm{mgd}$. The 10 public watersupply systems taking water from streams use a combined average of about $24 \mathrm{mgd}$, but during periods of heavy demand use as much as $38 \mathrm{mgd}$.

\section{RURAL DOMESTIC SUPPLIES}

All farm homes and all urban homes not using water from public water systems are assumed to use ground water exclusively. Rural water use is probably about $26 \mathrm{mgd}$.

\section{AGRICULTURAL USE}

There are many farm ponds in the Neuse River basin created by damming small streams or by devising hillside catchment basins to trap rainfall and surface runoff. These ponds are used for fishing, stock watering, and for irrigating farm crops. Prior to 1954, only a little surface water was used for irrigation. During the drought period in the summer and fall of 1954, however, the practice of irrigating farm crops and pastures greatly increased. No estimate of the total volume of surface water used for agriculture is available but the amount is probably very insignificant in relation to the total supply in the basin. The number of farms equipped to irrigate during dry seasons may be expected to increase greatly in coming years. 
Although there has been a significant increase in the use of ground water for irrigation, about $5 \mathrm{mgd}$ was used during the 1954 irrigation season of about 3 weeks and the use of ground water for supplemental irrigation is likely to increase greatly in the future. Larger volumes of ground water are used for watering stock. Many flowing wells on farms in the Coastal Plain section continuously withdraw ground water. All agricultural uses of ground water aggregated an estimated $3 \mathrm{mgd}$ in 1954.

\section{OTHER USES}

Waste disposal by industries and municipalities is one of the more important nonwithdrawal uses of streamflow in the Neuse River basin. Navigation and recreational activities in certain areas constitute a significant use of the surface waters of the basin.

Ground water is also used as the source of supply for motels, laundries, and air conditioning, and these miscellaneous uses of ground water account for an estimated $5 \mathrm{mgd}$.

\section{POTENTIAL SUPPLY}

\section{SURFACE WATER}

At the present time the demand for surface water of suitable quantity and quality is increasing rapidly. The industrial expansion in the State, gains in population, greater use of automatic home appliances, and widespread installation of irrigation equipment have caused an upsurge in the use of water. The withdrawal of surface water for these uses may be expected to increase in the future.

The present sources of surface water generally appear to be adequate to provide the quantities required in the near future for the continued development of the area. Although it is probable that in most places the present quantity of water withdrawal can be increased several times without danger of a shortage of supply, the demand for water in many localities will grossly exceed the minimum stream flow and additional storage facilities will be necessary. The adequacy of the surface-water supplies in several localities will depend in large measure upon pollution abatement. In the lower reaches of the Neuse and Trent Rivers and Swift Creek, water supplies must be located carefully to avoid serious contamination by salt water. 
Rainfall deficiencies during recent growing seasons have led to an increase in the volumes of water used for irrigation, and it may be expected that similar rainfall deficiencies in the future will necessitate additional increases in irrigation. Because of the State's humid climate, irrigation will not be practiced on the same scale in North Carolina as is done in the western states, but supplementary irrigation will undoubtedly be continued on an increasing scale.

\section{GROUND WATER}

Preliminary studies indicate that the quantity of water now withdrawn from ground-water reservoirs in the Neuse River basin is only a fraction of the total available supply. A great expansion of present ground-water development is feasible throughout the basin.

An exact determination of the potential ground-water supply that may be utilized in any given area can be made only by interpreting hydrologic data of many kinds, collected over a period of years. The ground-water program in North Carolina has been limited so far to general studies, so that detailed knowledge of the properties of the aquifers has not been obtained. Sufficient information is available, however, to suggest areas of possible expansion and to point out certain limitations on development.

Domestic ground-water supplies may be obtained generally throughout the Neuse River basin and present no great problem. Moderate supplies for municipal, industrial, or agricultural use are available at many places in the Piedmont and upper Coastal Plain, and large supplies may be obtained throughout the area underlain by the sand of Cretaceous age and limestone of Tertiary age. There are, however, two important restrictions on groundwater use in the basin which must be mentioned-spacing of wells and salt-water contamination.

When a well is pumped, the water level is lowered at the well so that water flows toward it from all directions (see p. 54). The distance from the well to which a measurable effect of pumping extends depends on the rate of pumping. Wells must, therefore, be properly spaced to prevent mutual interference. Because so many factors are involved in the proper spacing of wells, they cannot be discussed in this report. This problem is not imperative in the Piedmont or fall line areas where the permeability is relatively low and yields are small. In the area underlain by the very permeable sand of Cretaceous age and limestone of Tertiary age, however, where large yields are expected, the problem is more acute, especially as it relates to salt-water contamination. 
There are certain physical relationships between these bodies of water that may be briefly stated as follows: Under ideal conditions and at any given well site, for every foot of drawdown of the fresh-water level, the salt-water level will ultimately rise 40 feet.' A body of salt water is known to lie beneath the fresh water in the underground reservoir from the vicinity of Dover, in Craven County, to the coast. It is very important, therefore, that wells be properly spaced, not only to prevent their interfering with production from other wells, but also to prevent their combined production lowering water levels enough to allow salt water to rise into the wells and render them unfit for use.

In that part of the Neuse River basin where salt-water contamination is possible, most wells have excellent yields, some furnishing as much as $1 \mathrm{mgd}$. Under present conditions, heavy pumping may be safely continued or, at some places, increased without danger of contamination. Generally, it may be said that an industry requiring 0.25 to $1 \mathrm{mgd}$ may rely upon a private groundwater supply. Because of the necessity of spacing wells some distance apart, it may not be possible for an industry to have several heavily pumped wells on its property, whereas a municipality, being abhe to space its wells over several square miles, may furnish several additional millions of gallons daily for public uses, including industrial.

It must be emphasized, however, that geologic and hydrologic conditions differ enough from place to place to prevent the application of a "formula" that may govern all cases. Before installing a large ground-water system, a municipality or an industry should obtain as much information as possible about the geology of the aquifer and its hydrologic properties. It maybe necessary to drill several test holes to determine the depth to the salt-water body and the possibility of contamination. Although the potential supply of ground water is large and its withdrawal may be safely increased, to the greatest extent in the southeastern half of the Neuse River basin, each large installation should be given individual study and should be planned in consideration of other installations in the same general area.

\section{WATER LAWS}

In North Carolina water rights, with only a few important exceptions, are based on the principal of riparian rights established under the old English law and as interpreted from time to time by various courts.

In matters affecting public health, the statutes of North Carolina provide that the State Board of Health shall have control over 
domestic waste discharges where such discharges are into waters used as sources of public water supplies.

The North Carolina State Stream Sanitation Committee, by action of the General Assembly of 1951, was vested with the authority to establish standards applicable to the streams and watercourses of the State and with the responsibliity of classifying such waters. Within the limits of the enabling act, control as to the manner and extent of disposal of sewage and waste and the maintenance of established stream standards rest with this Committee. Industries contemplating locating in North Carolina should clear with the State Stream Sanitation Committee plans and proposals for the disposal of waste into the streams of the State.

The General Statutes of 1943 , as amended, provide that any person, firm, or corporation utilizing waters for irrigation that are taken from any stream, river, creek or lake in North Carolina, in an amount sufficient to substantially reduce the volume of flow, shall obtain a permit for such use from the Director of the Department of Conservation and Development.

Navigable streams are under the jurisdiction of Congress through its constitutional powers to "regulate commerce among the several States." This power extends to the nonnavigable tributaries of navigable streams if the navigable capacity of the navigable waterway or if interstate commerce is affected. Flood control is also recognized as a Federal responsiblity.

Control of navigable waters has been generally exercised by the Corps of Engineers, U. S. Army. Concurrent jurisdiction, however, is vested in the Federal Power Commission in the matter of permits and licenses where the construction and operation of hydroelectric installations are involved on navigable streams or tributaries thereto. The district office of the Corps of Engineers having jurisdiction over the navigable stream affected should be consulted where encroachment on a navigable stream is contemplated, or regarding any proposed impoundment of or diversion from such navigable stream or tributary thereto related to hydroelectric installations. The entire Neuse River basin lies within the present jurisdiction of the Wilmington, N. C., district of the Corps of Engineers.

\section{SELECTED BIBLIOGRAPHY}

American Water Works Association, 1950, Water quality and treatment, 2d ed. Billingsley, G. A., and Joyner, B. F., 1953, Chemical and physical character of surface waters of North Carolina, 1951-52: N. C. Dept. of Conserv. and Devel., Bull. 52, v.8. Collins, W. D., 1925, Temperature of water available for industrial use in the United States, 1925: U. S. Geol. Survey Water-Supply Papẹ 520-F, D. 97-104. 
Dole, R. B., 1909, The quality of surrace waters in the United States, pt. 1, Analysis of waters east of the one hundredth meridian: U. S. Geol. Survey Water-Supply Paper 236.

Harris, K. F., and Pauszek, F. H., 1951, Chemical Character of surface waters of North Carolina, 1949-50: N. C. Dept. of Conserv. and Devel. Bull. 52, v. 6.

Johnson, T. S., and Mann; C. L., Jr., 1938, Discharge records of North Carolina streams, 1889-1936: N. C. Dept. Conserv. and Devel., Bull. 39, 220 p.

Joyner, B, F., and Lamar, W. L., 1949, Chemical character of surface waters of North Carolina, 1946-47: N. C. Dept. of Conserv. and Devel. Bull. 52, v. 3.

Joyner, B. F., and Pauszek, F. H., 1949, Chemical character of surface waters of North Carolina, 1947-48: N.. C. Dept. of Conserv. and Devel. Bull. 52, v. 4.

Lamar, W. La, 1947, Chemical character of surface waters of North Carolina, 1944-45: N. C. Dept. of Conserv. and Devel Bull. 52, v. 1.

1948: Chemical character of surface waters of North Carolina, 1945-46: N. C. Dept. of Conserv. and Devel. Bull. 52, v. 2.

Lohr, E. W., and Love, S. K., 1955, The industrial utility of public water supplies in the United States, 1952, pt. 1: U. S. Geol. Survey Water-Supply Paper 1299.

Mundorff, M. J., 1945, Progress report on ground water in North Carolina: N. C. Dept. Conserv. and Devel., Bull. 47, 78 p.

1946, Ground water in the Halifax area,. North Carolina: N. C. Dept. Conserv. and Devel., Bull. 51, 76 p.

North Carolina Division of Commerce and Industry, 1936, North Carolina: Today and tomorrow: N. C. Dept. of Conserv. and Devel.

North Carolina Division of Water Resources and Engineering, 1947, Hydrologic data on the Neuse River basin 1866-1945: N. C. Dept. of Conserv, and Devel.

North Carolina Division of Water Resources, Inlets and Coastal Waterways, 1955, Water resources of North Carolina: N. C. Dept. of Conserv, and Devel.

North Carolina State Planning Board, 1937, A planning report on water resources of North Carolina.

Parsons, Brinkerhoff, Hall, and MacDonald, June 1954, Report on survey of North Carolina inland ports and waterways, prepared for N. C. Dept. of Conserv, and Devel.

Pauszek, F. H., 1950, Chemical character of surface waters of North Carolina, 1948-49: N. C. Dept. of Conserv, and Devel. Bull. 52, v. 5.

Pauszek, F. H., 1952, Chemical character of surface waters of North Carolina, 1950-51: N. C. Dept. of Conserv. and Devel. Bull. 52, v. 7.

Ray, C. E., Jr., and Randolph, E. E., 1928, Preliminary report on the chemical quality of surface waters of North Carolina with relation to industrial use: N. C. Dept. of Conserv. and Devel. Econ. Paper 61.

Saville, T., and Smith, G. W., 1925, Discharge records of North Carolina streams, 1889-1923: N. C. Dept. Conserv, and Devel., Bull. 34, 405 p.

Stiemke, R. E., February 1947, The extent of stream pollution in North Carolina: N. C. State Coll., Dept. of Eng. Research, Bull. 34.

United States Corps of Engineers, 1932, Report for the improvement and development of the Neuse River, N. C.: U. S. Cong. Doc., 72d Cong., 2d sess., H. Doc. 500.

United States Geological Survey, issued annually, Surface-water supply of the United States, pt. 2, South Atlantic slope and eastern Gulf of Mexico basins: U. S. Geol. Survey Water-Supply Papers.

issued annually, Surface-water supply of the United States, pt. 2A. South Atlantic slope basins, James River to Savannah River. U. S. Geol. Survey Water-Supply Papers.

United States Public Health Service, 1946, Drinking water standards: reprint 2697, 14 p., from Public Health Service Repts., v. 61, no. 11, p. 371-384.

United States Weather Bureau, issued annually, Daily river stages at river-gage stations on the principal rivers of the United States.

issued monthly and annually, Climatological data, North Carolina. 
. 


\section{INDEX}

A

Page

Abstract

Agriculture

Agricultural use of water .................... 80-81

Analyses of water...................... 47, 48, 58

Apex, public water-supply system ....67, 68-69

Aquifer, artesian............................... 53-54

Ayden, public water system........... 67, 68-69

\section{B}

Bailey, public water-supply system ..68-69, 70 Barton Creek, near Bayleaf.................16, 23,

Beaufort, public water-supply $26,35,39$

system................................... 68-69, 70

Benson, public water-supply system

Bibliography.................................. 84-85

Big Branch, near Millbrook

$27,35,39$

Black Creek formation................. 56, 62, 63

Buck Swamp, near Dudley............... 17, 24 ,

\section{C}

Cary, public water-supply system ....68-69, 71

Castle Hayne formation............................ 56

Chemical analyses of water, need for......... 12

Chemical quality of water, relation to streamflow....................... 46, 49-51

Chemical requirements of water............... 12

Chemical specifications for water.......... 12-14

Cherry Point, public water-supply system................................. 68-69. 72

Clayton, public water-supply system

$68-69,72$

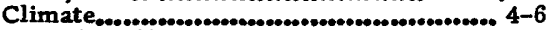

Coastal landforms

Coastal Plain, altitude description

rocks,

sources of water

Color in water, obj ections to

Contentnea Creek, at Hookerton, $29,30,35,39,48$

chemical quality of water................ 51-52 near Wilson........................... 17, 24, 30 , 39. $51-52$

regulation of flow..........................e........ 18

Core Creek, near Fort Barnwell.

Cove City, public water-supply system.............................. 68-69, 72

Crabtree Creek, near Raleigh........... 16, 23,

Creedmore, public water-supply

26, 35, 39

system.
Cretaceous sand province, aquifers in,....... 63 chemical analyses of water...0................. 58 depth and yield of wells, quality of water.................................. 64 Crystalline-rock province, chemical

analyses of water............................e....58 depth and yield of wells, permeability of

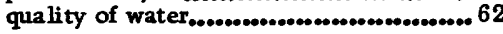

\section{D}

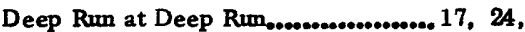
$28,35,39$

Definition of terms .............................99-10

Dial Creek, near Bahama.............16, 23, 26

Discharge, deficient, maximum $30,35,39$

period of.................................32-36

Dissolved solids in water.........14, 46, 49-51

Draft-storage curves.............................. 36

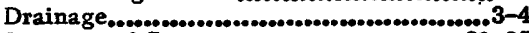

Duration of flow............es............e....... 20-25

Durham, public water-supply system

Eno River, at Hillsboro ..................16, 23, $26,30,35,39$

\section{$\mathbf{F}$}

Falling Creek, at Falling Creek ........17, 24, $28,35,39$

Fall line Farmville, public water-supply

system

Fisheries

Flat River, at dam near Bahama .......16, 23 , $30,35,39$ near Bahama............... 16, 21, 23, 26 , $30,31,35,36,39,40$ regulation of flow............................ 18 Flood-frequency curves, seasonal use of value of

Flood frequencies, studies...................... 43 Flood-stage frequencies, Neuse River... 44, 45

Flow-duration curve..................20, 21, 25

Fluctuation of water levels..................65-67

Forest resources........................................... 8 Foumtain, public water-supply system ............................. 68-69, 73 Fremont, public water-supply system.................e...e........... 68-69, 73 
G

Gaging stations, duration of records for.....e. 18 See also Stream gaging sites and Quality of water, ga jing sites.

Gamer, public water-supply system $68-69,73$

Geography ......................................... 2-3

Geology

Goldsboro, precipitation and temperature at. public water supply

Granite..............................55, 57, 61-62

Grifton, public watersupply

system............................. 68-69, 73-74

Ground water, chemical analyses of,.......... 58

chemical character of ............................ 59 definition

hardness of ............................................. 60

movement

occurrence

potential supply........................... 82-83

Ground-water provinces.......................... 57

Growing season,................................... 5

\section{H}

Hardness of water, chemicals causing .........14 graph of, for ground water,...................... 60 importance of........................................14 relation to dissolved solids...................... 50

Hillsboro, public water-supply system ................................68-69, 74 Hookerton, public water-supply system

Horse Creek, near Wake Forest..........16, 23,

$26,35,39$

Hydrogen-ion concentration......................10

Hydrologic cycle.............................. 10-11

\section{I}

Industrial development............................. 8 Introduction................................... 2-10 Iron in water, objection to $\ldots \ldots \ldots \ldots \ldots \ldots \ldots \ldots \ldots$ 14-15

\section{$\mathbf{K}$}

Kenly, public water-supply systems Kinston, public water supply..... $54,68-69,74$ Knightdale, public water-supply system ..................................68-69, 75

\section{L}

La Grange, public water-supply

system................................. 68-69, 75

Limestone-sand province.................... 64-65 Little River, near Princeton.........17, 22, 24, $28,30,34,35,38,39,42,51$

Low-flow frequency ......................... 25, 32 Lucama, public water-supply

system
$68-69,75$
M

Manganese in water, objection to ${ } . . . . . . .14-15$ Middle Creek, near Clayton,.....16, 22, 24,

$$
27,30,33,35,37,39,41
$$
near Smithfield Middlesex, public water-supply sys tem Mine Creek, near Millbrook,...en........16, 23, $27,35,39$

Mineral products..................................... 8 Moccasin Creek, near Middlesex...... 17, 24,

Morehead City, public water-supply $28,35,39$ system............................. 68-69, 75 Mount Olive, public water-supply system.............................. 68-69, 75

\section{$\mathbf{N}$}

Nahunta Swamp, near Snow Hill......17, 25, 29,39 Neuse River, at Kinston...........17, 24, 28, $30,35,39,45,47$ near Clayton $36,39,40,44,46,47,51$ near Goldsboro..................... 17, 24, 28, $30,35,39,45,47$ $30,35,39,44$

New Berm, precipitation and temperature at................................... 7

\section{$\mathbf{P}$}

Peedee formation.

Piedmont region, description................... 3 rocks............................................... 55 sources of water................................... 11 Pikeville, public water supply.......68-69, 76 Pink Hill, public water supply Population p..............................e.......en.. 2-3 Porosity of the rocks..................................52 Precipitation, .......................... 4-6, 7, 20 Princeton, public water supply ...... 68-69, 76 Public water supply, sources, Public water-supply systems ......... 67-79, 80 Pumping, effect of, on water level in wells, ............................................ 54

Purpose of the report

\section{Q}

Quality of water, for industrial uses......... 13 sampling sites for........................... 16-17 ground water significance of surface..................................... 46-52

\section{$\mathbf{R}$}

Raleigh, precipitation and temperature at.
public water supply $\quad 70-71,76-77$

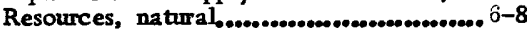


Salinity of water of the area

Salt-water encroachment

Selma, public water supply Shale rocks.......................... 55, 57, 61-62

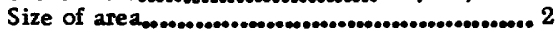

Slate province, depth and yield

$$
\text { of wells. }
$$

permeability of

62

Slate rocks........................... 55, $57,61-62$

Smithfield, public water supply.....51, 70-71, 77

Snow Hill, public water supply....... 70-71, 77

Soil moisture.......en...........................0. 10-11

Soils, 10-11

Specific conductanc e............................... 10

Stantonsburg, public water supply „o.... 70-71, 77

Stony Creek, at Goldsboro...... 17, 24, 28, 35, 39

Storage curves, use of .......................37, 43

Storage requirements

Streamflow, records of relation to chemical quality

of watex................................... 46, 49-51

Streamflow characteristics.............. 19-20

Stream gradients,

Stream-gaging sites............................. 16-17

Stream pattern

Streams, importance in colonial times ...... 15

Surface water, potential supply quality of ..................................... 46-52

Surficial sands

Swift Creek, chemical quality of water.0..... 52 near McCullers..............16, 23, 27, 35, 39 near Vanceboro ....... 17, 25, 29, 35, 39, 48

\section{$\mathbf{T}$}

Temperature

Terms, definitions,

Tertiary limestone province, chemical analyses of water........................... 58

depth and yield of wells., 64

permeability

quality of water
Topography

Transportation................................ 8-9

Trent River, near Trenton ........17, 25, 29 , $35,39,48,52$

Tuscaloosa formation.......................56, 62

\section{$\mathbf{W}$}

Wake Forest, public water supply... 70-71, 78 Walstonburg, public water supply... 70-71, 78 Water, agricultural use ................... 80-81 chemical specifications for............. 12-14 miscellaneous uses............................. 81 origin potential supply........................... 81-83 private industrial supplies public supplies ...................12, 67-79, 80 rural domestic supplies,....................... 80 sources of uses of

Water la Ws, Water levels in wells, fluctuations of.

Wells, depth of

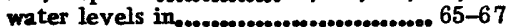
yield of Wendell, public water supply....... 70-71, 78 Wilson, public water supply.o.e...... 70-71, 78 Winterville, public water

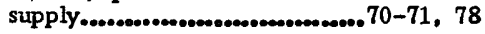

\section{$\mathbf{Y}$}

Yorktown formation

Youngsville, public water supply................................. 70-71, 79

$\mathbf{Z}$

Zebulon, public water supply 